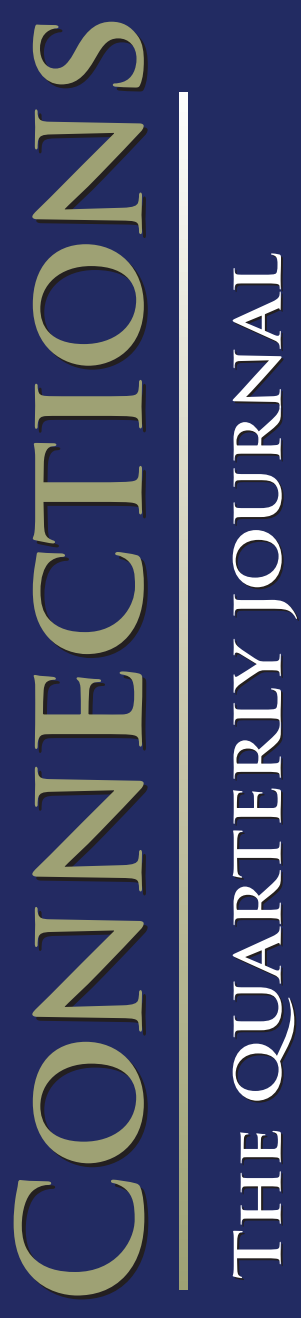

EUROPE'S ARMED FORCES IN CIVIL SECURITY

Johis L. Clarkse
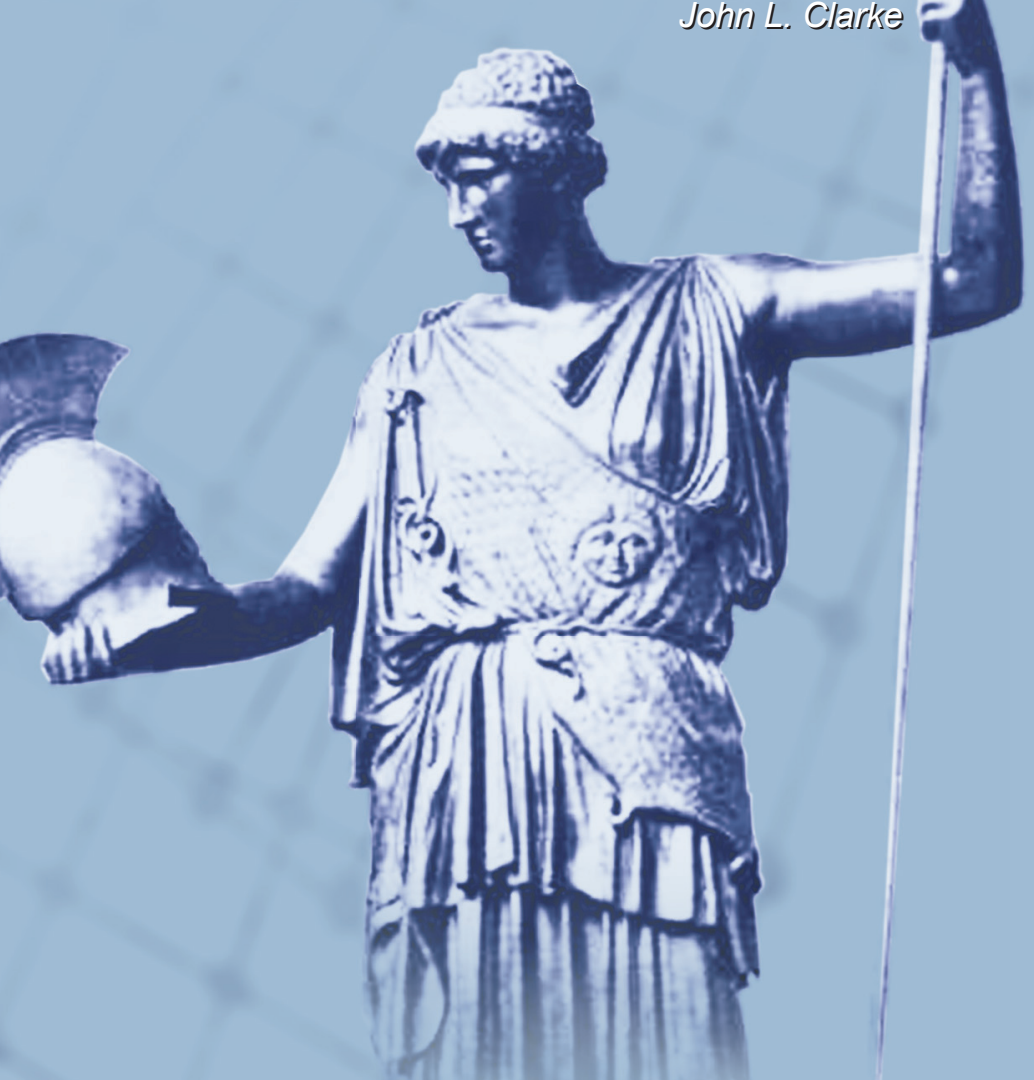

PARTNERSHIP FOR

PEACE CONSORTIUM

OF DEFENSE

ACADEMIES AND

SECURITY STUDIES

INSTITUTES
Central Asia and the Afghanistan Security Dilemma after 2014 Timothy A. Krambs

The Asymmetric Warfare Environment Giuseppe Caforio

Ballistic Missile Defense in Poland: Did the Costs Outweigh the Benefits? Steven D. Dubriske 


\section{Partnership for Peace Consortium of Defense Academies and Security Studies Institutes}

\section{The PfP Consortium Editorial Board}

Sean S. Costigan

Jean Callaghan

Aida Alymbaeva

Ernst Felberbauer

Peter Foot

Piotr Gawliczek

Hans-Joachim Giessmann

Graeme Herd

Elena Kovalova

David Mussington

Chris Pallaris

Tamara Pataraia

John Reppert

Philippe Sommaire

Todor Tagarev
Executive Editor

Managing Editor

Institute for Analysis and Initiatives Development, Bishkek Austrian National Defence Academy

Geneva Centre for Security Policy

National Defence University, Warsaw

Berghof Foundation

Geneva Centre for Security Policy National Defense University, Washington DC

The White House i-intelligence, Zurich

George C. Marshall European Center for Security Studies George C. Marshall European Center for Security Studies Bulgarian Academy of Sciences

\section{The PfP Consortium Publication Manager}

Enrico Müller

Partnership for Peace Consortium Operations Staff

The articles appearing in all Connections publications do not necessarily represent the views of the authors' institutions, their governments, or the PfP Consortium itself.

The Consortium's family of publications is available at no cost at https://pfpconsortium.org/node/5/journal. If you would like to order printed copies for your library, or if you have questions regarding the Consortium's publications, please contact the PfPC Operations Staff at pfpcpublications@marshallcenter.org. Should you have any problems with your subscription, please include the ID number found on the first line of the mailing label.

Dr. Raphael Perl

Executive Director
Sean S. Costigan

Chair, Editorial Board 


\section{CONNECTIONS \\ The Quarterly Journal}

Volume XII, Number 2

Spring 2013

Central Asia and the Afghanistan Security Dilemma: Amelioration, Retrograde, or Status Quo? Central Asia's Role in Regional Security Regarding Afghanistan after 2014

Timothy A. Krambs

Strategic Communication for Security \& National Defense: Proposal for an Interdisciplinary Approach

Cristian E. Guerrero-Castro

The Asymmetric Warfare Environment as Described by the Participants

Giuseppe Caforio

Europe's Armed Forces in Civil Security.....

John L. Clarke

NATO's Energy Security Policy Put to the Caspian Test

Nathan R. Grison

Ballistic Missile Defense in Poland: Did the Costs Outweigh the Benefits?

Colonel Steven D. Dubriske

GAO Report on Security Force Assistance

More Detailed Planning and Improved Access to Information Needed to Guide Efforts of Advisor Teams in Afghanistan 



\title{
Central Asia and the Afghanistan Security Dilemma: Amelio- ration, Retrograde, or Status Quo? Central Asia's Role in Regional Security Regarding Afghanistan after 2014
}

\author{
Timothy A. Krambs *
}

\section{Introduction}

The regional security of Central Asia hinges on the level of stability within Afghanistan and its foreign relations with its neighbors. ${ }^{1}$ Afghanistan is not only pivotal in the maintenance of regional security, but is also crucial to the region's economic and political development. As Ashraf Ghani, chairman of the Afghan transition commission, stated, "The region needs to make a choice, a stable Afghanistan ... is absolutely essential." ${ }^{2}$ However, there is looming doubt as to the ability of Afghan forces to be able to defend the state against domestic and external insurgent movements and to sustain the progress in counterterrorism and counterinsurgency that the U.S.-backed, NATOled International Security Assistance Force (ISAF) mission in Afghanistan has established under UN mandates since the United States initiated military action against the Taliban in 2001. The year 2014 is the deadline that has been set for ISAF troops to withdraw from the war-torn country and hand over the responsibility for ensuring security in the nation to the Afghan Security Forces. Currently the U.S. and NATO forces are transitioning from a mission of combat to one of support. ${ }^{3}$ The participants of the "Bonn+10" conference ${ }^{4}$ identified 2011 as the dividing point "From Transition to the

* Timothy A. Krambs is a Major in the U.S. Army Aviation Branch and a Foreign Area Officer for Eurasia. He served combat tours in the Middle East, worked and traveled throughout the region of Central Asia, and holds a master's degree in international security studies from the Universität der Bundeswehr München. The views expressed are solely those of the author and do not officially represent those of the U.S. government or its affiliated agencies. Research was limited to the access and use of only unclassified material, or material that has been vetted and authorized from the source's research database provider.

1 Central Asia is defined for the purpose of this paper to include the five near and bordering countries of Kazakhstan, Kyrgyzstan, Tajikistan, Turkmenistan, and Uzbekistan.

2 Anna Borshchevskaya, "Key Regional Perspectives: Central Asia," New Atlanticist Policy and Analysis Blog, Atlantic Council (18 November 2011); available at www.acus.org/ new_atlanticist/key-regional-perspectives-central-asia.

3 Latif Mohammadi, "2014 Withdrawal Dateline: An In-depth Study," in Daily Outlook Afghanistan, ed. Dr. Hussain Yasa (11 November 2011); available at http://outlookafghanistan.net/topics.php?post_id=2446. See also Katelyn Sabochik, "President Obama on the Way Forward in Afghanistan," The White House Blog (22 June 2011); available at http://www.whitehouse.gov/blog/2011/06/22/president-obama-way-forwardafghanistan.

4 The "Bonn+10" title signifies the ten-year anniversary of the original conference held in Bonn, Germany in 2001, where the international community established actions and goals to implement over the following decade to attain a peaceful end state for Afghanistan. 
Transformation Decade," during which the burden on the international community to assist Afghanistan in maintaining peace and continuing to develop its governmental reforms should gradually diminish. ${ }^{5}$ Several important questions require informed and insightful responses: During this "Transformation decade," what will the security picture in Afghanistan look like? Who will supplant the U.S. forces and complement the Afghan security forces to establish the necessary stability in Afghanistan to allow further economic and political development in the country and the region?

This article evaluates what kind of role the Central Asian states will play in Afghanistan after U.S. and NATO/ ISAF forces complete their withdrawal in 2014. Through a survey of regional media and analysis from renowned security agency assessments of these countries, I assess the interests and political will of each Central Asian state to provide their own security, and that of the region in dealing with Afghanistan. I also describe and compare regional trade and security cooperation efforts with relation to Afghanistan and to threats external to each respective state. These interests are then compared with each state's individual and collective capacity to fulfill them, considering a variety of characteristics related to leadership, economic strength, security and armed forces capacity, and national foreign policy dynamics, along with other factors that may inhibit future regional cooperation efforts. Finally, comparative analysis of these traits is displayed in a matrix format, which assists in determining future engagement approaches with Afghanistan on the part of each Central Asian state.

As a result of this research, I argue that the low levels of security force capacities, both historical and projected, of the Central Asian countries, their diverse levels of political will and corresponding goals regarding security operations in Afghanistan, and the lack of effective cooperation among the Central Asian states on a variety of related security issues will lead to their inability to cooperate in a comprehensive unified effort to establish stability in Afghanistan. Therefore, collectively, Central Asia will play only a minor role in continuing the U.S./ISAF security and stability operations in Afghanistan after 2014, directly affecting the regional security of Central Asia at large. Instead, the countries will continue as they have been doing, strategically creating a buffer zone of protection against any negative spillover effects resulting from any conflicts that may arise in Afghanistan. These conflicts include incursions from terrorist organizations, drug trafficking, and other organized crime. Furthermore, they will increase their reliance on either bilateral or multi-lateral security relationships with larger superpowers and regional organizations such as the U.S., Russia, or the Collective Security Treaty Organization (CSTO) and Shanghai Cooperation Organization (SCO) to supplant their weak military, drug control, and border security organizations, as well as other deficiencies within their respective security sectors.

\footnotetext{
"Conference Conclusions," in Afghanistan and the International Community: From Transition to the Transformation Decade, proceedings of The International Afghanistan Conference, Germany, Bonn, 5 December 2011; available at http://www.auswaertigesamt.de/cae/servlet/contentblob/603686/publicationFile/162762/Conference_Conclusions__International_Afghanistan_Conference_Bonn_2011_engl.pdf.
} 


\section{Kazakhstan}

Kazakhstan has a unique record of cooperating with developmental efforts in Afghanistan. Kazakhstan has supported peacekeeping operations under NATO auspices by providing officers to work in hospitals and ISAF headquarters, and by providing overflight rights and emergency access to its airports during Operation Enduring Freedom. Furthermore, it adapted a special plan on Afghanistan under which it allocated millions of dollars toward humanitarian assistance in the form of food grains given to the Afghan people, besides providing funds for state transport infrastructure and educational institution development. ${ }^{6}$ Kazakhstan's President Nursultan Nazarbayev reminded other heads of state in 2010 at the NATO Lisbon Summit that Kazakhstan was the first Central Asian country to join ISAF in support of the war effort in Afghanistan. ${ }^{7}$ Since then, Kazakhstan has transported non-military cargo for ISAF and coalition troops, and has offered a deeper supportive role in providing food and construction materials and training experts in civilian specialties. ${ }^{8}$

President Nazarbayev supports the Afghan president in holding that security can only be enhanced through established economic growth. Afghanistan's President Hamid Karzai stated during the 2011 SCO Summit in Astana that, although he hoped that the UN mission and the international troops will be withdrawn from Afghanistan by 2014 , the governmental institutions and the Afghan economy would "remain vulnerable." Therefore, further assistance in economic development will be required from the international community. ${ }^{9}$ When President Nazarbayev became president of the OSCE, he stressed that Afghanistan remained the most serious regional problem, and committed Kazakhstan to acting as a dedicated partner with the OSCE to restore the economy of Afghanistan as the most important goal to improve matters and achieve a calm and peaceful life for the Afghan people. He concluded, "Until we rebuild the economy, until we give work to the people, the only source of their livelihood will be drug trafficking. That is a global concern.... We say the economy first, then politics," pointing out that Afghanistan, like Kazakhstan and other post-Soviet countries, are not

6 Kanat Saudabayev, "Prepared Remarks by H.E. Kanat Saudabayev, Secretary of State of the Republic of Kazakhstan, at the NATO PA Plenary Session" (speech given to the NATO PA Plenary Session in Valencia, Spain, 18 November 2008); available at www.akorda.kz/en/ secretary_of_state/speeches/prepared_remarks_by_h_e_kanat_saudabayev_secretary.

7 Office of External Affairs, President of the Republic of Kazakhstan, "President Nursultan Nazarbayev Addresses a Session of the Euro-Atlantic Partnership Council (EAPC) on Afghanistan at the NATO Summit in Lisbon," 20 November 2010; available at http://www.akorda.kz/en/page/page_president-nursultan-nazarbayev-addresses-a-session-ofthe-euro-atlantic-partners_1348722984.

8 "Kazakhstan Sending Troops to Afghanistan Under UN Mandate - Minister," BBC Monitoring Central Asia Unit (27 May 2011). See also "Sending Troops to Afghanistan Could Pose a Threat to Kazakhstan's Security, Diplomat," Kazakhstan General Newswire (9 June 2011).

9 "Kazakhstan: Afghans to Assume Responsibility for their Security in 2014 - Leader," BBC Monitoring Central Asia Unit (15 June 2011). 


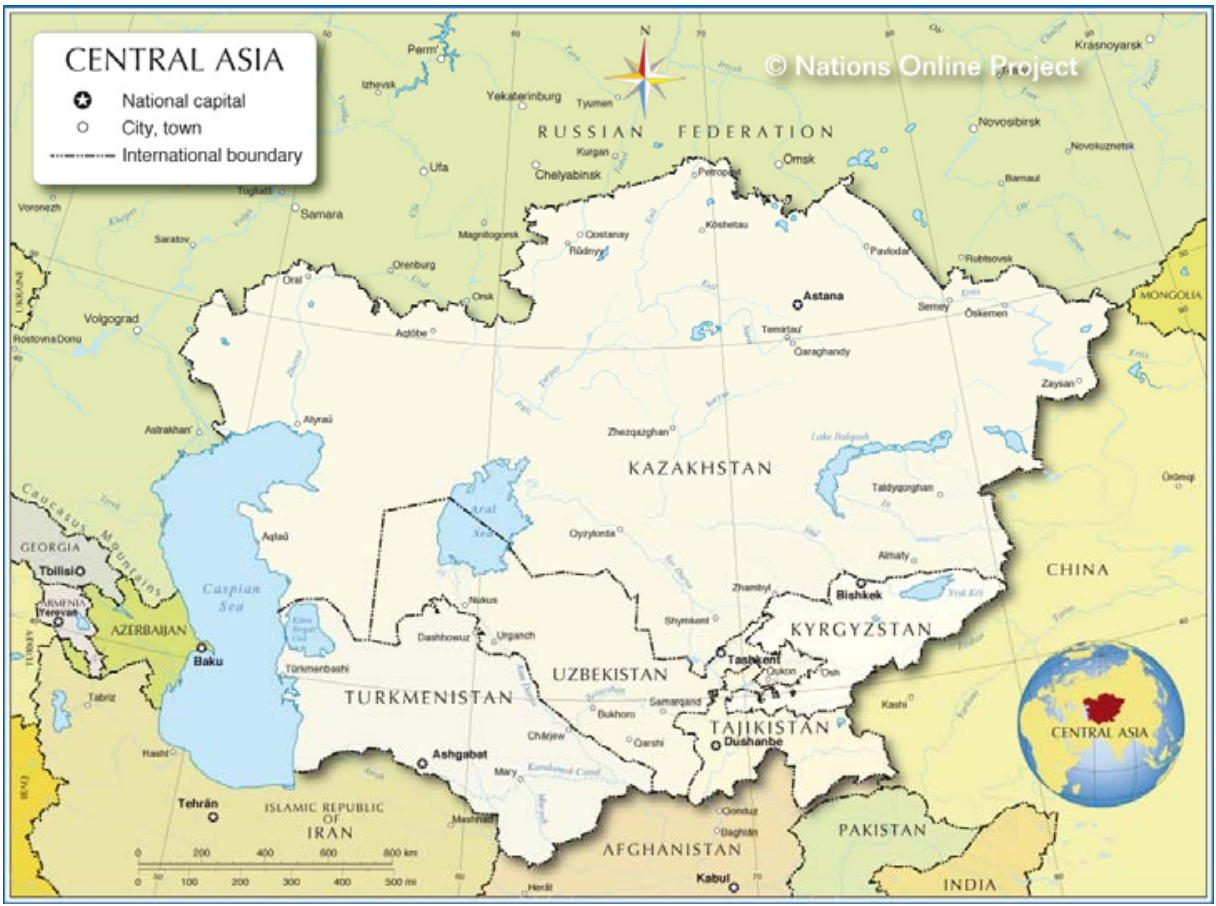

Figure 1: Map of Central Asia. ${ }^{10}$

ready for drastic changes. According to Nazarbayev, democracy needs time to develop gradually to convince the populations in these transition states of its merits. ${ }^{11}$

Kazakhstan's foreign policy focuses on developing healthy economic trade and strategic security relationships with a range of global powers to diversify its foreign relations towards Russia, the U.S., and Europe. ${ }^{12}$ President Nazarbayev boosted trade between the members of the Customs Union (CU), which consists of Russia, Kazakhstan, and Belarus. Trade with these countries increased 38 percent the first ten months of the union, and Kazakhstan's economic growth has increased twelve times since 1994. ${ }^{13}$

10 Map showing the Countries of Central Asia and adjacent countries with borders, capitals and main cities. Available at www.nationsonline.org/oneworld/map/central-asia-map.htm.

11 Interview of Nursultan Nazarbayev by Denis Loktev, "Nazarbayev: 'Economy First, Then Politics," Euronews (15 January 2010); available at www.euronews.com/2010/01/15/ nazarbayev-economy-first-then-politics/.

12 IHS Janes, "External Affairs," in "Country Report - Kazakhstan," Jane's Military and Security Assessments (IHS Global Unlimited, 2011).

13 Greg Delaney, "President Nazarbayev - Address to the Nation 2011 (highlights)," KazakhstanLive.com (1 January 2011). 
However, Kazakhstan is wary of yielding too much to influence from Moscow. U.S. bilateral security arrangements with Kazakhstan have also been established. In late 2011, Kazakh Deputy Foreign Minister Konstantin Zhigalov supported the ratification of a proposed protocol on amendments to the agreement between the U.S. and Kazakhstan to create another commercial rail transit route for special cargo and personnel on Kazakh territory near the Kazakhstan-Uzbekistan border. This agreement was "in connection with the [United States'] participation in efforts to stabilize and rebuild the Islamic Republic of Afghanistan, [and] meets a key foreign policy goal set by President Nursultan Nazarbayev to create a security belt around our country." ${ }^{14}$ The U.S. has supplied equipment and counterterrorism training for Kazakh troops. However, the Kazakh President precluded the U.S. or NATO states from basing aircraft in Kazakhstan, as they have done previously in Uzbekistan and currently do in Kyrgyzstan. Kazakhstan has expressed a desire to increase cooperation with NATO, but does not want to become a full-fledged member, in fear of unduly antagonizing Russia. ${ }^{15}$ Kazakhstan has also looked to international organizations and multi-lateral engagements to enhance efforts to counter terrorism, insurgency, and illicit drug trafficking from Afghanistan. ${ }^{16}$ As the current chair country of the CSTO in 2012, Kazakhstan remains one of its most active members.

Unfortunately, Kazakhstan's security relationships with its Central Asian neighbors are highly variable. ${ }^{17}$ Kazakhstan is worried about Kyrgyzstan's inability to arrest its own problems of social welfare and poverty, which has produced chronic political infighting and social instability. Additionally, issues such as labor migration from Kyrgyzstan, water disputes, transit of goods, and border demarcation work against building positive Kazakh-Kyrgyz relations. Kazakh-Uzbek border disputes still stifle cooperation, and corruption, tax rules, customs obstacles, or other bureaucratic issues (most on the Uzbek side) have historically hampered economic ties. More positively, Kazakhstan, Russia, and Turkmenistan agreed in 2007 to build a pipeline along the Caspian coast, to transport mostly Turkmen gas to Europe. President Nazarbayev supports the idea of transporting Turkmen gas via Kazakhstan and Uzbekistan to China using the existing Kazakh energy infrastructure. ${ }^{18}$

Corruption is a key problem throughout Kazakh society. The absence of mechanisms for democratic control or accountability, combined with the high concentration of resources within the higher echelons of government, has allowed corruption to infect all levels of government. As a result, corruption is evident in Kazakh bureaucracy and at every stage of the judicial process, providing governmental impunity and making independent investigations nearly impossible. Kazakh army officials have in the past

\footnotetext{
14 "Kazakh MPs Approve Bill on New Transit Point for US Cargo to Afghanistan," BBC Monitoring Central Asia Unit (2 November 2011).

15 IHS Janes, "External Affairs," in "Country Report-Kazakhstan."

16 "CSTO to Work at Building Collective Air Defense System in CA," Kazinform (21 February 2012); available at http://inform.kz/eng/article/2442774.

17 IHS Janes, "External Affairs," in "Country Report - Kazakhstan."

18 Ibid.
} 
embezzled millions of dollars worth of military budget allocations. Furthermore, the rise in illicit trafficking is linked to pervasive corruption among Kazakhstan's customs and security services. Even today, it remains a mystery to what extent Kazakh state officials are involved in the drug trade.

Kazakhstan is a relatively economically strong and stable nation in comparison with its regional neighbors. However, it still relies on bilateral relationships with world powers as well as dedicated membership and active participation in international organizations to aid its economic development and enhance its strategic regional security. ${ }^{19}$ The importance President Nazarbayev places on its trade and security relationships with Russia and China leads me to believe that it will look to these countries and the security alliances in which they play a leadership role more so than to the U.S. as the NATO/ISAF troops withdraw from Afghanistan, even though Kazakhstan attempts to uphold a balanced foreign policy with the West and Asia. Furthermore, Kazakhstan's past history of diplomatic and indirect international support in Afghanistan through humanitarian assistance and economic development projects indicate that future actions will continue to carry a defensive character, as President Nazarbayev pursues a "security belt" approach in his security policy with Afghanistan.

\section{Kyrgyzstan}

Kyrgyzstan is not only concerned about the transnational threats from Afghanistan that affect its own security, but also about how they affect the stability of the entire Central Asian region. At a recent interview in Brussels, Kyrgyzstan's former interim president, Roza Otunbayeva, stressed: "The region is becoming increasingly insecure because of the activities of the international force in Afghanistan. Military violence is coming increasingly close to our borders. Right now, jihadist groups are active everywhere. They are waiting for their opportunity. I am concerned about the very porous border between Kyrgyzstan and Tajikistan and that between Tajikistan and Afghanistan." ${ }^{20}$ Miroslav Niyazov, a retired Major-General of Kyrgyzstan's State National Security Committee, shares a similar concern that Afghanistan has been and remains a source of illicit narcotics, and the U.S./NATO troop withdrawal will cause his country's security to deteriorate. $^{21}$

Despite this concern, Kyrgyzstan's newly elected and appointed political elite continue to focus internally on resolving domestic issues rather than on any expressed intent to provide direct support in Afghanistan in response to the NATO/ISAF troop withdrawal. During his presidential inauguration speech, the former Kyrgyz Prime Minister Almazbek Atambayev swore to develop and protect the interests of Kyr-

19 IHS Janes, "Security," in "Country Report-Kazakhstan."

${ }^{20}$ Chris Hensen, “'Jullie Weten Dat Wij Een Brandhaard Zijn.' Instabiliteit in Centraal-Azië President Roza Otoenbajeva Van Kirgizië Vertelt over Haar Angst Voor Chaos En Geweld (Interview with Kyrgyz President Otunbayeva in Brussels Warning of Regional Chaos)," NRC Handelsblad Online (2 March 2011).

21 "Central Asian States Not to Benefit from US Afghan Pullout-Kyrgyz General," BBC Monitoring Central Asia Unit (23 June 2011). 
gyzstan looking north towards Russia, with whom Kyrgyzstan has "a common history and future," but nothing was mentioned regarding cooperation towards a regional solution for stability in Afghanistan. ${ }^{22}$ At the end of 2011, upon being elected as the new President of Kyrgyzstan, Atambayev focused on domestic affairs. While acknowledging that Kyrgyzstan is still recovering from ethnic turmoil in 2010, he affirmed that further inter-ethnic turmoil would not be tolerated. Issues involving security, terrorism, and drug trafficking remain only as "acute problems." The political scientist Aida Alymbayeva has mentioned that all of Kyrgyzstan's recent efforts have focused on preserving political and ethnic stability in its own country by "establishing relationships between the political elites." ${ }^{23}$ However, Kyrgyz Foreign Minister Ruslan Kazakbayev did shed a ray of hope in a meeting with the Afghan Ambassador to Kyrgyzstan, when he stressed that ensuring regional security against drug trafficking and religious extremism remains the focus in regional cooperation. The Kyrgyz government's plan to implement their share of regional security cooperation is to work with the OSCE in training Afghan custom officers in Kyrgyzstan, and to participate in conferences and projects directed towards the economic restoration of Afghanistan. ${ }^{24}$ However, such good intent is indirect in nature, and has yet to yield substantial or measurable results.

Kyrgyzstan is the home of the Manas Transit Center near Bishkek. Although Manas is recognized as the most important transshipment and refueling point for the U.S. and NATO in support of operations in Afghanistan, its validity is losing political clout as the integrity of the Kyrgyz government and the transit center's cost/benefit ratio is put into question. ${ }^{25}$ The U.S. invested USD 123.5 million into the Kyrgyz economy in support of the airbase in 2010. Today, payments to the Kyrgyz government are sustained at USD 60 million annually. Unfortunately, some believe most of this money fuels corruption and lines the pockets of sitting politicians.

Kyrgyzstan, like other Central Asian states, has a history of straddling the political fence with its foreign policy to leverage national interests for economic benefit or strategic security support, and will likely continue to do so. ${ }^{26}$ Former Kyrgyz Presidents Akayev and Bakiyev were known to play political games with both the U.S. and Russia for economic support and security. In 2009, for example, President Bakiyev fell to Russian pressure to revoke U.S. rights to use Manas air base in return for financial

${ }^{22}$ Reuters, "KYRGYZSTAN: Newly-inaugurated President Almazbek Atambayev Says He Will Strengthen and Protect His Nation and Build Relationships with Neighbouring Countries," ITN Source (2 December 2011).

23 Asker Sultanov, "Atambayev Reviews 2011 Achievements," Central Asia Online (29 December 2011); available at http://centralasiaonline.com/en_GB/articles/caii/features/ main/2011/12/29/feature-02.

24 "Kyrgyz Foreign Minister, Afghan Envoy Discuss Security, Drug Fight," BBC Monitoring Central Asia Unit (6 February 2012).

25 "Russian Paper Says USA Uses Kyrgyz Base to Ferry Troops to Central Asia," $B B C$ Monitoring Former Soviet Union - Political (9 June 2011).

26 IHS Jane's, "Foreign Relations," in "Country Report-Kyrgyzstan," Jane's Military and Security Assessments (IHS Global Limited, 2011). 
investment and supplies for its military. ${ }^{27}$ However, shortly thereafter, Bakiyev agreed to cooperate with the U.S. on an agreed lease of over triple the rent paid in previous years. $^{28}$ In June 2011, Kyrgyzstan's Foreign Minister Ruslan Kazakbayev praised cooperation with Moscow, while expressing hope that U.S.-Kyrgyz relations would continue to prosper in the security sector and in efforts to combat drug trafficking through its newly reopened Drugs Control Agency. Simultaneously, former Prime Minister Almazbek Atambayev and his deputy, Omurbek Babanov, groomed relations with Kazakhstan and Russia. ${ }^{29}$ Recently, the Kyrgyz National Security Committee's border service received USD 16 million worth of military hardware from Russia, which is only half of the scheduled aid from a Russian program dubbed "Brothers Fighting for Fixed Borders." This further reinforces President Atambayev's claim that Russia is Kyrgyzstan's “main strategic partner." 30

Kyrgyzstan supplements its military weaknesses not only with strategic bilateral relationships, but with ties to regional security organizations as well. Kyrgyzstan's defense capabilities are weak, and unable to defend the country against incursions even of small groups of radical Islamist militants. The successful attacks in Kyrgyzstan from the Islamic Movement of Uzbekistan (IMU) in 1999 and 2000 are proof of Kyrgyzstan's security shortcomings. Other radical Islamist groups such as Hizb ut-Tahrir (HuT) and the Islamic Jihad Union (IJU) are also active, some of which have claimed attacks in neighboring Uzbekistan and Tajikistan. Although the reform of the security sector has been initiated, little progress has been made, and Ministry of Defense sources admit that more than half of their Kyrgyz conscripts are unfit for military service. $^{31}$ Therefore, Kyrgyzstan's security is reliant on both economic and military alliances. These include NATO's Partnership for Peace (PfP) program and the Central

27 "Russian Paper Says USA Uses Kyrgyz Base to Ferry Troops to Central Asia."

28 Lieutenant-General U.S. Army (Ret.) David W. Barno, Andrew Exum, and Matthew Irvine, Beyond Afghanistan: A Regional Security Strategy for South and Central Asia, report, 25 May 2011, 16.

29 Erica Marat, "Kyrgyzstan's Chaotic Foreign Policy," Eurasia Daily Monitor 8:121, The Jamestown Foundation (23 June 2011); available at www.jamestown.org/

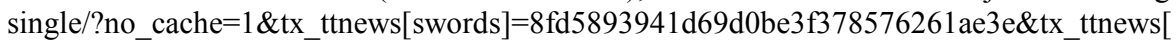
any_of_the_words] $=$ Yemen\&tx_ttnews[pointer] $=3 \& t x \_t$ tnews[tt_news] $=38087 \& t x \_$ttnews[ backPid] $=381 \& \mathrm{cHash}=12078 \mathrm{e} 23 \mathrm{~b} 0 \mathrm{eb} 7463 \mathrm{a} 945 \mathrm{~b} 91 \mathrm{db} 5565 \mathrm{c} 76 \# . \bar{U}$-3-O1OxM7A.

30 Deirdre Tynan, "Central Asia: Russia Taking Steps to Reinforce Security Relationships," EurasiaNet.org (2 February 2012); available at www.eurasianet.org/node/64946.

31 IHS Jane's, "Defense," in "Country Report-Kyrgyzstan." 
Asia Cooperation Organization (CACO). ${ }^{32}$ Understanding that both Moscow and Beijing have a strong vested interest in maintaining stability in Central Asia, Kyrgyzstan is also a member of the Shanghai Cooperation Organization and the Collective Security Treaty Organization. Officially, both the Kant air base and a new facility being constructed in the south of Kyrgyzstan are not strictly Russian bases, but military facilities of the CSTO. Bishkek also hosts the secretariat coordinating the CSTO's Collective Operational Reaction Force (CORF). ${ }^{33}$

Besides being unpredictable, with inconsistencies in its foreign policy and deficiencies in its military strength, Kyrgyzstan has other characteristics that hinder its capability to be effective in contributing directly to regional security efforts in light of Afghanistan's U.S./ISAF troop withdrawal. The new parliamentary system established by former President Roza Otunbayeva still suffers from infighting and struggles to exert political control over semi-autonomous southern regions in Osh and Jalalabad, where ethnic violence that flared in June 2010 still haunts the region. ${ }^{34}$ Kyrgyzstan is still one of the poorest former Soviet states, so its potential and capacity to assist financially in fostering Afghanistan's stability remains low. Kyrgyzstan produces hydroelectric power for domestic and export purposes. However, decreasing water levels and increasing domestic demand has yielded low profits and extensive electricity shortages. Unemployment estimates of 10-20 percent, exacerbated by weak economic and job growth potential, forces many Kyrgyz nationals to seek work elsewhere. ${ }^{35}$ Furthermore, narcotics trafficking, organized crime, and corruption remain endemic problems in Kyrgyzstan. Even the Kyrgyzstan Drugs Control Agency "has so far proven to be as ineffective and corrupt as the rest of the country's law enforcement bodies." 36

The prospects for Kyrgyzstan's future contribution to any "war on terror" in Afghanistan and associated contributions towards regional security efforts seem bleak. Although Kyrgyzstan's former leadership considers that Afghanistan's situation is dire, and its current foreign minister advocates that a comprehensive security strategy is

32 The Central Asian Cooperation Organization (CACO) was initially created under the name of Central Asian Economic Union in 1994, by Kazakhstan, Kyrgyzstan, and Uzbekistan. Tajikistan joined the group in 1998, and the organization was then renamed the Central Asian Economic Cooperation (CAEC). On 28 February 2002, the CAEC was transformed into the Central Asian Cooperation Organization. The recent integration of Russia into the agreement (28 May 2004) is very likely to change the center of gravity of CACO. The main focus of $\mathrm{CACO}$ is presently the improvement of regional safety and stability as the basis for further improvement in the economic situation in the region. For more on this topic, see: http://ecetrade.typepad.com//Central\%20Asian\%20Cooperation\%20Organization $\% 20$ basic\% 20info.doc.

33 IHS Jane's, "Executive Summary," in "Country Report-Kyrgyzstan."

34 Roman Muzalevsky, "Key Risks Facing Central Asia in 2012 and Beyond," Eurasia Daily Monitor 9:27, The Jamestown Foundation (8 February 2012); available at www.jamestown.org/single/?no_cache $=1 \&$ tx_ttnews[tt_news] $=38985 \&$ tx_ttnews[backPid] $=$ $13 \& \mathrm{cHash}=617585 \mathrm{be} 26 \mathrm{c} 5232803 \mathrm{a} 2 \mathrm{a} 60 \mathrm{ccec} 22 \mathrm{c} 17 \#$.Ue3_G1OxM7A.

35 IHS Jane's, "Economy," in "Country Report-Kyrgyzstan."

36 IHS Jane's, "Drug Trafficking," in "Country Report-Kyrgyzstan." 


\section{THE QUARTERLY JOURNAL}

needed, newly elected President Atambayev has focused on resolving domestic issues, relying on international organizations and regional security alliances to compensate for Kyrgyzstan's inability to effectively contribute to regional security efforts. Instead, Atambayev has only offered to assist the regional stability effort by training Afghan forces on its own territory. Kyrgyzstan's lack of military or financial strength, engrossed involvement in its own domestic affairs, and inconsistent political ambitions make it a weak candidate for any direct contribution in Afghanistan as more ISAF/ NATO troops continue to withdraw from Afghanistan through and even after 2014.

\section{Tajikistan}

Tajikistan is deeply concerned about its own security as well as that of the region. However, history has proven Tajikistan's insufficient capability to counter transnational threats relative to the Central Asian region. In his address to the Supreme Assembly (Majlisi Oli) on 25 April 2011, President Emomali Rahmon noted that security and stability in Afghanistan was necessary for Central Asia, particularly for Tajikistan "as much as the air we breathe." The president reaffirmed that, "Addressing modern threats and challenges and joint struggle against other negative phenomena, as well as helping and promoting Afghanistan's efforts, training necessary personnel for Afghanistan in our country and other areas will always be in the spotlight of the agenda of our cooperation with this friendly country." ${ }^{37}$ Unfortunately, history has proven that the means to meet such good intentions may not be within reach. During the most deadly civil conflicts in Tajikistan from 1992 to 1997, government forces battled against radical Islamists and local warlords in fighting that resulted in thousands killed and/or internally displaced, and threw 80 percent of the Tajik population into poverty. Only through brokering deals with political factions, keeping peacekeepers at a minimum, and tolerating disruptive warlords as a necessary evil was Tajikistan successful in becoming "tolerably stable." It opted for a laissez-faire approach, integrating warlords into the political scene while still allowing them to retain their substantial autonomy. ${ }^{38}$ Although the 1997 peace accords were established with the Islamist-dominated United Tajik Opposition (UTO), the frequency of cross-border militant activity of the IMU insurgency or other armed groups has increased since 2009. ${ }^{39}$ After the pitiful display of resistance that Rahmon's forces put up against the insurgency uprising that occurred in the eastern region of Rasht in 2010-11, Tajiks now fear that their tattered security

37 President Emomali Rahmon, "Address by the President of the Republic of Tajikistan His Excellency Emomali Rahmon to Majlisi Oli on Key Directions of Internal and Foreign Policy of the Republic of Tajikistan" (address, Dushanbe, 25 April 2011).

38 George Gavrilis, "The Tajik Solution: A Model for Fixing Afghanistan," Foreign Affairs (22 November 2009); available at www.foreignaffairs.com/articles/65690/george-gavrilis/thetajik-solution.

39 IHS Janes, "Security" and "Executive Summary," in "Country Report - Tajikistan," Jane's Military and Security Assessments (IHS Global Limited, 2011). 
forces will not be able to withstand further offensives from the IMU ${ }^{40}$ even more so as the planned withdrawal of NATO forces from Afghanistan by 2014 begins to commence. $^{41}$

Tajikistan's armed forces, domestic security, and border patrol units remain weak. Motivation among the population to serve in the armed forces is dismal, therefore draft-dodging, desertion and banditry are frequent. With only USD 60 million dedicated to the defense budget, the pace of military transformation is extremely slow. Even though Russia's Federal Security Service (FSB), the U.S., China, and the UNODC have provided training and financial aid to assist in addressing the massive narcotics trafficking and "Islamist militants" problems along the Tajik-Afghan border, Tajikistan's Committee for State Border Protection (KOGG) remains "underfunded, poorly trained and equipped, and fails to protect the Afghan border..." A vast majority of illegal narcotics trafficking passes by the Tajik border guards, and significant clashes have recently increased with Islamists insurgents, which have left scores of militants and KOGG personnel dead. Institutional corruption furthermore prohibits the KOGG from stemming the flow of drugs across the border. ${ }^{42}$

As a result, Tajikistan relies on its bilateral and multi-lateral relationships to supplement its meager security efforts. Russian instructors train the Tajik National Guard to defend Rahmon's regime, and Tajikistan's most capable fighting force, the 1st Special Operations Brigade, follows Russian airborne forces' doctrine and training methods. Since 1999, Tajikistan has supported Russia's military installation called Okno ("window"), which tracks any flying objects up to $40,000 \mathrm{~km}$ above Central Asia. Russia's 201st motor rifle division is considered the best-equipped and most combat ready force in Tajikistan, and serves as the basis of the CSTO's Collective Operational Reaction Force (CORF). ${ }^{43}$ During a quadrilateral meeting in Dushanbe in September 2011, Tajikistan agreed to jointly strengthen its effective cooperation with the SCO, CSTO, UN, and OIC, and to host the Fifth Regional Economic Cooperation Conference on Afghanistan (RECCA V) in March 2012. ${ }^{44}$

Tajikistan is most likely to provide economic support to transform Afghanistan through collaborative efforts with Russian-based organizations and agreements. At last year's OSCE meeting in Vienna, the Tajik foreign minister stressed the importance of the four-party framework of governments from Tajikistan, Afghanistan, Pakistan, and

40 Andrew Stroehlein and Kimberly Abbott, "Tajikistan: The Changing Insurgent Threats," International Crisis Group, Report no. 205 (24 May 2011), Executive Summary and Recommendations; available at www.crisisgroup.org/en/publication-type/media-releases/2011/asia/ tajikistan-the-changing-insurgent-threats.aspx.

41 "Tajikistan Fears Security Threat after NATO Troops Withdrawal from Afghanistan," Russia and CIS Military Newswire (19 December 2011).

42 IHS Janes, "Executive Summary," "Security," and "Foreign Forces," in "Country ReportTajikistan."

43 Ibid., "Security" and "Foreign Forces."

44 "Afghan, Pakistani, Tajik, Russian Leaders Sign Joint Statement," BBC Monitoring Central Asia Unit (2 September 2011). 


\section{THE QUARTERLY JOURNAL}

the Russian Federation, as well as that of collaboration in implementing joint projects, including the CASA-1000 project - an economic initiative planned to provide $1000 \mathrm{MW}$ of electricity from Tajikistan to Pakistan, through Afghanistan. In his view, such projects as this and "the training and professional development of civilian and military personnel and the construction of railways, highways, and bridges linking our countries" contribute to the rehabilitation of Afghanistan. Furthermore, it was hoped that trade and tourism would flourish as the frequency of direct flights between the two countries increased. ${ }^{45}$

Unfortunately, Tajikistan still remains the poorest country in the region. A World Bank poverty assessment in 2003 showed that 64 percent of households in Tajikistan lived under the poverty line. High unemployment and its poor economy have driven nearly 800,000 residents to become migrant workers, who send inconsistent remittances home due to the unstable and depressed world economy. Susceptible to drought and dependent on others for natural gas, Tajikistan has suffered financially from low levels of production in its cotton and aluminum industries, and of other chief exports such as hydroelectricity. Therefore, outside assistance is required to prevent Tajikistan's economy from imploding. ${ }^{46}$

However, Tajikistan has cleverly benefited from international aid stemming from the conflicts in Afghanistan. In his address to the Majlisi Oli, President Emomali Rahmon stressed the importance of "constructive cooperation" with the United States and European Union as members of the "antiterrorist coalition ... fighting against terrorism, extremism, illegal drug trafficking and transnational organized crime." 47 Tajikistan profits from "win-win" developmental projects, which Tajik officials insist must be constructed on their side of the border with Afghanistan. ${ }^{48}$ A recent pact with Russia (signed in September 2011) ensured "the preservation of the Russian presence in Tajikistan [and] participation of Russian representatives in the improvement of state border protection and the operational border security of the Republic of Tajikistan."49 Furthermore, recent ratifications of earlier agreements with Russia to receive Russian

45 Hamrokhon Zarifi, "Statement by Mr. Hamrokhon Zarifi, Minister for Foreign Affairs of the Republic of Tajikistan, at the 856th Meeting of the OSCE Permanent Council" (speech, 856th Meeting of the OSCE Permanent Council, Austria, Vienna, 31 March 2011); available at www.tjus.org/latest-news/107-statement-by-mr-hamrokhon-zarifi-minister-for-foreignaffairs-of-the-republic-of-tajikistan-at-the-856th-meeting-of-the-osce-permanent-council. See also "Electricity Projects on Top of Ahmadinejad's Agenda," Somoso.com News (15 February 2012); available at http://www.somoso.com/news/electricity-projects-on-top-ofahmadinejads-agenda/.

46 IHS Jane's, "Executive Summary," in "Country Report - Tajikistan."

47 President Emomali Rahmon, "Address by the President of the Republic of Tajikistan His Excellency Emomali Rahmon to Majlisi Oli on Key Directions of Internal and Foreign Policy of the Republic of Tajikistan."

48 George Gavrilis, "Why Regional Solutions Won't Help Afghanistan: The Myth of Neighborly Harmony," Foreign Affairs (18 October 2011); available at www.foreignaffairs.com/ articles/136598/george-gavrilis/why-regional-solutions-wont-help-afghanistan.

49 Tynan, "Central Asia: Russia Taking Steps to Reinforce Security Relationships." 
advisory personnel, training, transportation, and equipment assistance with Tajikistan's Border Control further solidifies Tajikistan's reliance on Russia for its security needs. However, India may compete with Russia for the right to use Tajikistan's Ayni airfield due to its historic investment of nearly USD 70 million toward refurbishments, ${ }^{50}$ providing opportunity for the Government of Tajikistan to profit economically and politically from collaborative security interests. ${ }^{51}$

Tensions between Tajikistan and its Central Asian neighbors continue to prevent regional cooperation. Improperly marked borders result in sporadic clashes with subsistence farmers, and shootouts occur occasionally between border guards from Kyrgyzstan, Uzbekistan, and Tajikistan as they have allegedly attempted to assist civilians in cross-border crime. As a result of disagreements over natural gas payments, Uzbekistan closed its border with Tajikistan in 2008, and disputes over landmines planted in 1999 and 2000 in response to IMU incursions continue to flare up. Tajikistan strongly objected to Uzbekistan's withdrawal from the Central Asian unified energy grid in 2009, which deprived the Tajiks of Turkmen electricity. In response, Tajikistan is attempting to break its dependence on Uzbek energy supplies by building a major hydropower station in Rogun, which will transform Tajikistan into a net electricity exporter. ${ }^{52}$ Even today, a fence still separates the two countries, and repeated border skirmishes have prompted Uzbekistan to move tanks closer to its border with Tajikistan. ${ }^{53}$

Corruption and narcotics trafficking remain significant problems in Tajikistan. As the Drug Control Agency (DCA) in Tajikistan recognizes increases of up to 61 percent in opium production in Afghanistan, the UN International Drug Control Program (UNDCP) reports that the Tajik DCA has successfully intercepted only 3 to 4 percent of the total of narcotics trafficked through the country. ${ }^{54}$ Understaffed and underpaid police and security forces in Tajikistan capitalize on illicit profits from narcotics trafficking, and consequently are not capable of enforcing the security measures needed to protect the porous 1350-km Tajik border with Afghanistan.

Although the President of Tajikistan and other political elites understand and have voiced the sentiment that security and stability in Afghanistan is as necessary "as the

50 Alexander Sodiqov, "Dushanbe and Moscow Disagree over Russia's Use of Ayni Airbase," Eurasia Daily Monitor 8:28, The Jamestown Foundation (9 February 2011); available at www.jamestown.org/single/?no_cache=1\&tx_ttnews[swords] $=8$ fd5893941d69d0be3f378576 261ae3e\&tx_ttnews[any_of_the_words] $=$ ayni\%20airbase\&tx_ttnews[tt_news] $=37478 \&$ tx_tt

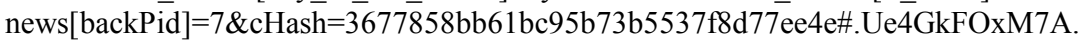

51 “Tajik Parliament Ratifies Tajik-Russian Agreement on Border Cooperation," Russia and CIS General Newswire (29 February 2012).

52 IHS Jane's, "Security," in "Country Report-Tajikistan."

53 Roman Muzalevsky, "Key Risks Facing Central Asia in 2012 and Beyond."

54 The increase of 61 percent was in comparison of results in 2011 to those of the previous year as reported by the Ministry of Counter-Narcotics of Afghanistan of the UNODC. Remarkably, production in the northern Tajik bordering province of Badakhshan rose 55 percent last year alone. For more information, see "Increase in Opium Production in Afghanistan Gives Cause for Concern," Tajikistan News-NA "Asia-Plus" (26 January 2012); available at http://news.tj/en/news/increase-opium-production-afghanistan-gives-cause-concern. 
air we breathe," the political will to pursue the measures necessary to establish the security required is simply not evident. Tajikistan's poor economic condition and its inability to stem the corruption so prevalent among the forces needed to provide security in its country further prevent it from being an active or effective contributor to any regional stability effort. ${ }^{55}$ Instead, Tajikistan has been shown to profit from a dysfunctional Afghanistan by obtaining continued financial benefit and military support from larger superpowers such as Russia and the U.S. Furthermore, its capacity to intercede militarily in Afghanistan in order to defend its own people is woefully inadequate. Tajikistan must continue to rely on the political and military support of regional organizations, preferring those in which Russia has the largest influence. Therefore, Tajikistan is most likely to pursue a passive role in support of Afghanistan's stability, preferring that Afghanistan advocate a laissez-faire style of compromise with the Taliban, similar to the way the Tajik government had to conciliate with its opposition during its exhausting civil war in the 1990s. Tajikistan will hold a defensive stance against any insurgency, relying on the collaborative efforts of the CSTO or SCO to facilitate effective intervention, while it remains engaged in protecting itself or negotiating to overcome the differences it has with its other Central Asian neighbors.

\section{Turkmenistan}

Turkmenistan's isolationist foreign policy has hindered its development, causing it to be the slowest former Soviet state to progress economically. Since Turkmenistan gained independence, former Turkmen President Niyazov established a series of societal and political reforms under a policy publicly known as "permanent neutrality," which isolated it from the outside world and provided him with lifetime control of the country. After Niyazov's sudden death in December 2006, President Gurbanguly Berdymukhammedov has done little to improve the well-being of the citizens of Turkmenistan, and has only opened its doors to the outside world in a very controlled and slow manner. By maintaining a highly controlled and oppressive regime he is able to stem all political opposition and theoretically reduce the risk of popular unrest. Furthermore, Turkmenistan's new leadership has yet to diversify its economic activity beyond the energy sector. Virtually none of the Turkmen gas revenue has been invested into other areas of the economy, increasing the nation's financial risk from a potentially unstable source of income. Turkmenistan's lack of transparency in its budget makes assessing its growth unreliable and unpredictable. Consequently, major multilateral financial organizations are prevented from providing desperately needed financial assistance to help Turkmenistan invest in diversifying and developing its economic sector. ${ }^{56}$

This isolationist stance has contributed to unstable relations between Turkmenistan and its Central Asian neighbors, which may have a sharply negative effect on a col-

55 IHS Janes, "Executive Summary," in "Country Report - Tajikistan."

56 IHS Janes, "Executive Summary," in "Country Report-Turkmenistan," Jane's Military and Security Assessments (IHS Global Limited, 2011). 
laborative approach in dealing with regional security. Turkmenistan is the only Central Asian state to not participate in any sub-regional organizations such as the Eurasian Economic Community (EURASEC), CACO, CSTO, and the SCO. ${ }^{57}$ Uzbekistan has regular disputes with Turkmenistan over the latter state's construction of the "Lake of the Golden Century," concerned that the creation of the lake from the Amu Darya River will deprive it of its water needs downstream. Furthermore, tensions regarding border delimitation between the two nations have led to stricter visa regimes and border controls. ${ }^{58}$ However, during a visit to Tashkent in May 2011, President Berdymukhammedov and Uzbek President Karimov agreed that cooperation in settling the Afghan problem with its neighboring countries must be established, and that a military solution was impossible to establish peace in Afghanistan. The two countries further emphasized expanding trade and economic cooperation between them, particularly in the fuel and energy sector, applauding their success in constructing the TurkmenistanUzbekistan-Kazakhstan-China gas pipeline project launched in $2009 .{ }^{59}$

However, economic cooperation with Afghanistan has failed to generate any real results. After the U.S.-led invasion in Afghanistan, concerns over regional security prevented investment in the Trans-Afghan Pipeline (TAP) between Turkmenistan, Afghanistan, and Pakistan. Then again, in 2010 a new agreement was reached with Iran to build a 1700-km Turkmenistan-Afghanistan-Pakistan-Iran (TAPI) pipeline, $735 \mathrm{~km}$ of which will run through the Taliban heartlands in southern Afghanistan ${ }^{60}$ Although the countries involved have the will to realize the project, further challenges beyond security such as pricing, gas certification, technical capacity, and funding make the economic and political agreements harder to solidify. ${ }^{61}$

Turkmenistan's contributions to regional security with respect to the conflict in Afghanistan remain indirect and diverse. The Government of Turkmenistan has been the least cooperative state in the region in terms of supporting the U.S. and NATO forces in complying with the UN mandate in Afghanistan. Turkmenistan was the only Central Asian state that did not support offensive operations in Afghanistan during the onset of the military campaign in 2001, but since then has allowed extensive air and ground transport use for NATO and international humanitarian relief agencies to provide humanitarian assistance. ${ }^{62}$ Although willfully supporting NATO supply aircraft, President

57 Ibid., "Executive Summary" and "External Affairs."

58 Ibid., "External Affairs."

59 "Uzbek Leader Says Compromise Alone Can Solve Afghan Problem-Fuller," BBC Monitoring Central Asia Unit (7 May 2011).

60 Rainer G. Palau, "The TAPI Natural Gas Pipeline: Status and Source of Potential Delays," Afghanistan in Transition Report (February 2012); available at http://reliefweb.int/sites/ reliefweb.int/files/resources/CFC_Afghanistan_InBrief_Afghanistan_Displacement.pdf.

61 Emma Graham-Harrison, "Afghanistan Says Confident Can Secure TAPI Gas Pipeline," Reuters (22 September 2010).

${ }^{62}$ IHS Janes, "External Affairs," in "Country Report-Turkmenistan." 
Berdymukhammedov reaffirmed in 2009 that no foreign bases are to be established in Turkmenistan. $^{63}$

Unfortunately, Turkmenistan is a poor example and a weak role model to the Afghan security forces in their transition effort. Turkmenistan's military sector is a debacle, as its armed forces are ill-equipped, untrained, and notably the weakest in the Central Asian region. Despite Berdymukhammedov and other senior defense officials promising military reform, the armed forces have yet to receive new equipment or better training; since 2001, the Turkmen military has relied on conscription to meet its personnel requirements. Instead of focusing on external threats, national armed forces are used to combat internal dissent, guard stockpiles of old Soviet-era equipment (which they are incapable of maintaining), or work on farms, as traffic police, or as untrained medical assistants. ${ }^{64}$ Furthermore, Turkmen security forces are noted for their ineffectiveness, holding a reputation of being unprofessional, brutal, and highly corrupt, as the police have sweeping powers of oversight, surveillance, and detection. Despite U.S. assistance with border security training and resources, Turkmenistan suffers from low standards in personnel and surveillance efforts, which consist of only occasional land and air patrols and a few underequipped and undermanned checkpoints. ${ }^{65}$ Although a new counterterrorism unit and a State Drug Agency were developed in recent years, their effectiveness is waning. During a visit by the UNODC, it was noted that although it is recognized that the methodology to clean up the drugs situation in Afghanistan is known, no solution can be realized unless there is combined political will and partnership capacity is enhanced ${ }^{66}$ to put forth such programs as the UNODC's Regional Program for Afghanistan and Neighboring Countries. ${ }^{67}$

Turkmenistan's isolationist foreign policy since independence has severely hindered its development politically, socially, militarily, and has also prevented it from collaborating with its neighbors on a cooperative regional security policy. Instead, the political elite has focused more on bilateral relationships on those rare occasions when the opportunity has been to its own advantage. Although Turkmenistan has exerted recent efforts to reverse its historical isolationist policy and build financial bridges with its neighbors, its lack of financial diversification, poor standard of living, and lack of capacity to provide the necessary security to do so has prevented the fruition of such initiatives. The proposed TAPI gas pipeline has promising benefits for Afghanistan and its neighbors; however, even this proposal has been hindered by disagreements among

63 Ibid., "Security" and "Foreign Forces."

64 Ibid., "Executive Summary."

65 Ibid., "Security" and "Foreign Forces."

66 Jelena Bjelica, "Afghan Minister of Counter Narcotics and UNODC Visit Turkmenistan and Tajikistan," UNAMA: United Nations Assistance Mission in Afghanistan (30 October 2011); available at http://unama.unmissions.org/Default.aspx?tabid=1783.

67 See United Nations Office on Drugs and Crime (UNODC), "Drug Trafficking-Central Asia," at www.unodc.org/unodc/en/drug-trafficking/central-asia.html for more information on the UNODC's Regional Program for Afghanistan and Neighboring Countries created with the aim to increase the capacity of the countries of the region in combating drug trafficking. 
its investors on pricing, technicalities, and the lack of promised security along its route. In order for Turkmenistan to be an effective player with Afghanistan, drastic reforms must be implemented in its military, economic, and security sectors to almost the same degree that Afghanistan itself needs. Without the political will to take more action in reforming its own country, Turkmenistan is highly unlikely to have the will or capacity in the near future or after 2014 to intercede in Afghanistan.

\section{Uzbekistan}

Uzbek society is highly respected by some as "motivated, diligent, and well-educated." However, President Islam Karimov and his "family" have administered such a "benighted, corrupt, and brutal regime" that his family members are able to manipulate Uzbek society at will. The Karimov regime is notorious for committing multiple human rights violations, dictating court decisions, directing police raids on economic competition, ordering arrests, and for convincing evidence of torture, beatings, and assassinations. The post-Soviet "kleptocratic" family of President Karimov (essentially the Government of Uzbekistan) has successfully exploited the nation's wealth and has suppressed all opposition, leaving only clandestine Islamist groups to remain. ${ }^{68} \mathrm{Uz}-$ bekistan has topped the charts as one of the most corrupt countries in the world, and is categorized as number one in the world in exploiting child labor and as a source for both human trafficking in the sex trade and migrant slave workers who are forced to work in CIS labor camps. ${ }^{69}$ The nation is classified as not functioning as a democracy, a place where opposition politicians are systematically imprisoned on false charges, tortured and murdered. In short, some consider it as the "nastiest dictatorship in Central Asia." 70

Domestic threats are not Karimov's primary concern. However, the groundswell of unrest that is driven by the extreme poverty, corruption, and governmental repression of any political opposition or non state-sanctioned religion has provided an opportunity for trained Islamist militants to return to Uzbekistan and glean young recruits frustrated by such austere conditions. ${ }^{71}$ Three militant Islamist groups-the Islamic Movement of Uzbekistan (IMU), the Islamic Jihad Union (IJU), and the Hizb ut-Tahrir (HuT) - represent the largest external threat to Uzbekistan, and all three have links to Afghanistan. The multiple successful attacks by the IMU in Uzbekistan and Kyrgyzstan in 1999 and 2000 and the IJU gun and suicide bomb attacks in Tashkent in March and July 2004

68 Scott Horton, "Uzbekistan as a Values Challenge for NATO," Harper's Magazine (5 March 2012); available at www.harpers.org/archive/2012/03/hbc-90008467.

69 "Uzbekistan - Rotten to the Core but Number 1 in Some Important Categories," Uznews.net (18 February 2012); available at www.uznews.net/news_single.php?lng=enandcid= 31 andnid $=19128$.

70 Andrew Johnson, "Don't Work with This Dictatorship, London Metropolitan University Told," Islington Tribune (17 February 2012); available at www.islingtontribune.com/news/ 2012/feb/don\%E2\%80\%99t-work-dictatorship-london-metropolitan-university-told.

71 IHS Janes, "Executive Summary," in "Country Report - Uzbekistan," Jane's Military and Security Assessments (IHS Global Unlimited, 2011). 
and in the Fergana Valley in May 2009 collectively exposed the inability of the Central Asian states to regionally collaborate on creating a convincing response to terrorism in the region, which further destabilized the Fergana Valley. ${ }^{72}$ In 2001 , Karimov gained significant political leverage and protection when Uzbekistan became a coalition partner in assisting the U.S.-led effort in Afghanistan by leasing the Karshi-Khanabad (K2) military base to the U.S. and the Termez base to the Germans. However, since the Uzbek government forced the U.S. to leave the K2 base after relations between them deteriorated in the wake of violence in Andijon in 2005, ${ }^{73}$ and since U.S. troops have more recently transferred security responsibility to the Afghan National Security Forces (ANSF), threatening activity within certain sectors of northern Afghanistan has come to pose an increasing concern to the Central Asian states. By relocating to preOctober 2001 bases, the IMU fighters have been able to more easily blend in with the two million ethnic Uzbeks living in northern Afghanistan, and have revived their founding goals to "liberate" the Fergana Valley, overthrow the Karimov regime, and establish the Islamic Caliphate called "Turkistan." 74

President Karimov expressed concern during his recent address to Uzbekistan's armed forces that the removal of U.S. and ISAF forces from Afghanistan by 2014, "could lead to expansion of terrorism and extremism activities, growth of tension and contradiction in this vast region [Central Asia], as well as creation of a permanent source of instability here." Taking a more defensive stance regarding the threat of insurgency from Afghanistan, one of his key objectives was to reform the Uzbek military and increase their combat readiness to ensure that "well-trained, strong, fully-equipped armed forces are capable to ensure security of our country.", 75

President Karimov understands that in order to meet the feared challenges ahead, he must not only modernize and reform the Uzbek military, but he also needs to outsource his security to a certain extent. ${ }^{76}$ Responding to fears of revolutionary movements in 2003-05 in Georgia, Ukraine, and Kyrgyzstan, Uzbekistan drew closer to the Russian- and Chinese-dominated SCO, and also became a member of the EURASEC. It also rejoined the Russian-led CSTO in 2008. However, Karimov is opposed to too much Russian influence, and does not wish to support regional organizations' rapid-reaction forces, such as the CSTO CORF. Uzbekistan has worked with Russia in military training of officers and joint training exercises, but Karimov continues to balance overtures of cooperation with Russia, NATO, and the U.S. President Karimov has participated in NATO's PfP program, and proposed the inclusion of NATO in a ' $6+3$ '

72 Ibid., "Executive Summary" and "Non-state Armed Groups."

73 Gregory Gleason, "The Uzbek Expulsion of U.S. Forces and Realignment in Central Asia," Problems of Post-Communism 53:2 (March/April 2006): 49-60.

74 Jacob Zenn, "IMU Reestablishes Bases in Northern Afghanistan," CACI Analyst (8 February 2012); available at www.cacianalyst.org/?q=node/5710/print.

75 "Islam Karimov Says, Region Becomes Object of Close Attention," UzDaily.com (13 January 2012); available at www.uzdaily.com/articles-id-17077.htm.

76 Annette Bohr, "US-Uzbekistan Ties against Afghani Backdrop," interview on Voice of Russia Radio (4 February 2012); available at http://english.ruvr.ru/2012/02/04/65299936.html. 
structure to promote collaborative efforts with the Central Asian states, the U.S., Russia, and NATO in stabilizing Afghanistan. ${ }^{77}$

Karimov has sustained a more current multi-vectored foreign policy to diversify and yet balance his diplomatic relations with the superpowers and other regional neighbors that are so keen to invest in his strategic country for the sake of security and their financial investments in the region. Just as the U.S. has recognized Uzbekistan's strategic significance in the region as the main artery into Afghanistan via the Northern Distribution Network (NDN), Karimov understands his strategic importance provides political influence as a pivotal key to achieve what he wants from both the U.S. and Russia. ${ }^{78} \mathrm{He}$ is also justifiably concerned about the possibility of drugs or arms being smuggled into Uzbekistan along with "retro cargo" as it exits Afghanistan. ${ }^{79}$ Therefore, on 18 January 2012, U.S. Secretary of State Hillary Clinton lifted the ban against U.S. military assistance to Uzbekistan, previously established in 2005, so that "non-lethal" defensive assistance could be provided to Uzbek forces to protect them against any militant retaliation as they provide assistance with the transit of U.S. and NATO materiel to and from Afghanistan. ${ }^{80}$ Such provisions provide Uzbekistan with the geopolitical clout to show Russia that other options exist for security assistance other than the CSTO or bilateral security arrangements with Moscow. ${ }^{81}$

Uzbekistan tends to pursue bilateral relations with Afghanistan, rather than cooperate in regional solutions for collective trade and security. After being uncooperative during economic summits, regional trade, and multilateral counter-narcotic efforts with Afghanistan, ${ }^{82}$ and by not signing the Istanbul Process declaration, Uzbekistan did complete construction of a major rail line into northern Afghanistan in $2011 .^{83}$ The Asian Development Bank (ADB) is one of Uzbekistan's key lending partners whose support has enabled Uzbekistan to be the first and only supplier of round-the-clock electricity to Kabul as well as to construct and manage the major rail line into Afghanistan in support of ISAF forces. ${ }^{84}$

Unfortunately, Uzbekistan is further hindered from being a regional security contributor due to high levels of corruption, its poor economy, and enduring conflicts be-

77 IHS Janes, "Armed Forces" and "External Affairs," in "Country Report-Uzbekistan."

78 Kirill Zubkov, "The U.S. Will Help Uzbekistan to Disperse Demonstrators 'Not Lethally'," Defense and Security (Russia) (6 February 2012).

79 Joshua Kucera, "Russia to Host NATO Afghan Transit Hub?" EurasiaNet.org (3 February 2012); available at www.eurasianet.org/node/64953.

80 News Briefing Central Asia interview with Farhod Tolipov, “Afghan Worries Prompt US Defence Aid for Uzbekistan," Institute for War and Peace Reporting (16 February 2012); available at http://iwpr.net/report-news/afghan-worries-prompt-us-defence-aid-uzbekistan.

81 Joshua Kucera, "Uzbekistan to Get U.S. Night-Vision, GPS, Body Armor," EurasiaNet.org (2 February 2012); available at www.eurasianet.org/node/64944.

82 George Gavrilis, "Why Regional Solutions Won’t Help Afghanistan."

83 Chris Cork, "Unsafe Roads," SA GlobalAffairs (28 February 2012); available at www.saglobalaffairs.com/special-features/1147-unsafe-roads.html.

84 D. Azizov, “ADB Remains Key Partner of Uzbekistan,” Trend News Agency, Baku, Azerbaijan (18 February 2012). 
tween Uzbekistan and its neighbors. The efficiency and effectiveness of the Uzbek government is affected by the lack of accountability and nepotistic clan structure of Karimov's regime. Such corruption further facilitates persistent illicit drug trafficking in the region. Uzbekistan's remains a Soviet-style economy, where production is centrally controlled although the country is heavily privatized. Poverty remains endemic due to a lack of reform and constrained economic growth. Although Uzbekistan has abundant natural resources in cotton, gold, and natural gas, regional economic cooperation is hindered by restrictive trade barriers, high tariffs, and cumbersome border controls. The Fergana Valley region is the most susceptible to unrest, with a history rich in ethnic conflicts. In 1989 conflicts emerged between the Uzbeks and Meshkhetian Turks, and more recently in May-June 2010, when Kyrgyz and Uzbeks violently clashed in Kyrgyzstan's Osh and Jalal-Abad provinces. Reportedly thousands were killed, injured, or displaced during this conflict. Approximately 100,000 fled to Uzbekistan to temporary refugee camps, only to be forced to return only two weeks later. ${ }^{85}$ A recent railway explosion at a bridge on Uzbekistan's rail route paralyzed transport of goods between the Termez terminal and Tajikistan. Although the blast was categorized as a "terrorist act," it inflicted the most damage on Tajikistan's rail system, suggesting that the act may have more to do with Uzbekistan's opposition to the Rogun Dam project than with terrorism. ${ }^{86}$

The future of Uzbekistan's contributions to regional stability efforts in light of the U.S. and NATO troop withdrawal through 2014 seems to be more defensive in nature, understanding that President Karimov's fears of insurgency or weapons and drug infiltration coming from Afghanistan remain a significant threat. Although his rule is aging and his brutal and repressive regime has bred social unrest domestically and has been highly criticized internationally, his successful suppression of any opposition and tight control within Uzbekistan against religious extremism or any foreign spill-over effects from neighboring countries prevents the likelihood of any sort of overthrow of the regime in the near term. While President Karimov intends to reform his security and

85 IHS Janes, "Executive Summary" and "Security," in "Country Report-Uzbekistan." Also note that various sources provide conflicting data on the number of Uzbeks displaced, numbers killed, or how many migrated between the two countries. For example, Uzbek sources have claimed 7000 casualties; see Anna Matveeva, Kyrgyzstan in Crisis: Permanent Revolution and the Curse of Nationalism, CSRC Working Papers 79 (London: Crisis States Research Center, 2010), 1; available at http://www2.lse.ac.uk/internationalDevelopment/ research/crisisStates/download/wp/wpSeries2/WP792.pdf. The Kyrgyzstan Inquiry Commission (KIC) report (May 2011) counts 470 deaths, 1900 personnel receiving medical assistance, and more than 300,000 displaced; a separate 111,000 ethnic Uzbeks temporarily migrated to Uzbekistan before being sent back shortly thereafter. See Kimmo Kiljunen, comp., Kyrgyzstan Inquiry Commission (KIC) Report of the Independent International Commission of Inquiry into the Events in Southern Kyrgyzstan in June 2010 (3 May 2011), ii; available at www.k-ic.org/images/stories/kic_report_english_final.pdf.

86 “Doubts over Real Target of Uzbek 'terror' Blast," Times of Central Asia (Bishkek) (9 February 2012); available at www.timesca.com/index.php/m-news-by-category/other-centralasian-news/4868-doubts-over-real-target-of-uzbek-terror-blast. 
armed forces in the near future, with the help of U.S. military aid, he understands the need for additional external support for security, and therefore relies on the strategic significance of his country to take full advantage of the political, financial, and military support that he needs from regional superpowers to supplement his country's deficiencies. When we consider the difficulty Uzbekistan has effectively cooperating with its neighbors, its economic interest in supplying Afghanistan with electricity, and developments in its transport infrastructure, coupled with its incapacity to project its armed forces, it appears most likely that Uzbekistan will resort to focused bilateral security engagements with Afghanistan versus partaking in a regional approach.

\section{Central Asian States Assessment}

As the Central Asian matrix shows (Table 1), each Central Asian state has a variety of characteristics that make it unique. Kazakhstan stands out as the strongest overall, with a healthy political concern for regional security regarding the withdrawal of U.S. and NATO forces from Afghanistan, a healthy economy, an abundance of natural resources along with a highly developed industrial sector, and manages the most cooperative and balanced foreign policy. This enables Kazakhstan to generate security and economic reforms that allow its security and armed forces to be more effective in cooperating with both bilateral and multi-lateral approaches to resolve security issues. In contrast, Turkmenistan is the epitome of other comparable Central Asian states, who are more concerned with domestic affairs than other security issues concerning the region. It also lacks a diversified or developed economy, which puts it at great risk and renders it an unreliable partner in effectively addressing regional security concerns. The Turkmen government is trying to diverge from its chronic isolationistic mentality, but such reform is slow, and its interests external to its territory are mostly social or economic in nature, rather than security related.

Kyrgyzstan and Tajikistan suffer from the poorest economic conditions, and are also concerned primarily with their own domestic issues rather than the situation in Afghanistan. However, they do share the volatile Fergana Valley region with Uzbekistan, an area where the militant Islamists, particularly the IMU, IJU, and HuT are striving to establish an autonomous Islamic caliphate. Such extremist groups and other insurgencies are becoming burgeoning threats to the governments of these three countries, especially as they regroup in northern Afghanistan, where security responsibility has been handed over to the ANSF. Uzbekistan - even with such a repressive, brutal, and corrupt regime - has stronger security and armed forces and is more strategically located to influence the outcome of any instability that may arise from Afghanistan and spread into the region. With such a center of gravity, Uzbekistan has influence to fulfill what security needs it has, and maximize any potential economic benefits with its multi-vectored foreign policy. Uzbekistan will most likely continue to pursue strong bilateral relationships rather than multi-lateral solutions to resolve regional issues. Collectively assessing these characteristics and comparing the interests and varying political wills from within the region, one can easily see that a regional solution to a regional security problem will be hard to attain. The relatively disruptive and uncoop- 
Table 1. Central Asian matrix.

\begin{tabular}{|c|c|c|c|c|}
\hline & INTEREST & \multicolumn{3}{|c|}{ POUTICAL WU } \\
\hline & Stated Concern for Afghanistan & Past Support for Afghanistan & Planned Support for Afghanistan & Bi- or Multi-lateral approach \\
\hline 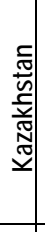 & $\begin{array}{l}\text { 1) Fears Unstable Afghanistan produces regional } \\
\text { instability } \\
\text { 2) Leadership in OSCE and OIC to develop } \\
\text { regional security and economic relations }\end{array}$ & $\begin{array}{l}\text { 1) Humanitarian aid } \\
\text { 2) Financial aide for infrastructure } \\
\text { 3) Educational institutional development } \\
\text { 4) Transport non-military cargo for ISAF } \\
\text { 5) Overflight rights for ISAF }\end{array}$ & $\begin{array}{l}\text { 1) Financial support } \\
\text { 2) Positive example for stable and modern } \\
\text { Islamic nation } \\
\text { 3) Social restoration } \\
\text { 4) Economic development through } \\
\text { increased trade } \\
\text { 5) Continued infrastructure development }\end{array}$ & $\begin{array}{l}\text { BOTH } \\
\text { 1) Emphasis on Multi-Lateral } \\
\text { 2) Strong Coop mindset with } \\
\text { CSTO \& SCO, EURASEC, } \\
\text { Eurasian Customs Union }\end{array}$ \\
\hline 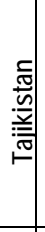 & $\begin{array}{l}\text { 1) Increased Insurgency threat } \\
\text { 2) Narcotics infiltration most tangible threat 3) } \\
\text { Atthough security inextricably linked to } \\
\text { Afghanistan, Tajik financial benefits from Afghan } \\
\text { instability }\end{array}$ & $\begin{array}{l}\text { 1) Training security personnel } \\
\text { 2) Political, security, military, and trade cooperation } \\
\text { with Afghanistan } \\
\text { 3) Overflight rights for ISAF }\end{array}$ & $\begin{array}{l}\text { 1) Not only military action req'd } \\
\text { 2) International economic and financial } \\
\text { institutional dev. } \\
\text { 3) Training prof. civ. \& military for } \\
\text { construction of transport infrastructure } \\
\text { 4) Train for coop. in education, sports, } \\
\text { culture }\end{array}$ & $\begin{array}{l}\text { BOTH } \\
\text { 1) Four-party security and socio- } \\
\text { economic framework (Tajik, } \\
\text { Afghan, Pakistan, Russia) } \\
\text { 2) CASA-1000 electric power } \\
\text { project } \\
\text { 3) Coop w/ SCO, CSTO, UN, OIC }\end{array}$ \\
\hline 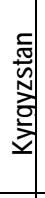 & $\begin{array}{l}\text { 1) Former President Otunbayeva strongly } \\
\text { concerned } \\
\text { 2) Current President Atambayev domestically } \\
\text { focused } \\
\text { 3) MFA concerned that drug trafficking and } \\
\text { religious extremism requires regional cooperation }\end{array}$ & $\begin{array}{l}\text { 1) Manas Airbase lease to U.S. to support } \\
\text { NATO/ISAF transit } \\
\text { 2) Overflight rights for ISAF }\end{array}$ & $\begin{array}{l}\text { 1) Work with OSCE training Afghan customs } \\
\text { officers in Kyrgyzstan } \\
\text { 2) Conference participation for economic } \\
\text { reform in Afghanistan }\end{array}$ & $\begin{array}{l}\text { MULTI-LATERAL } \\
\text { Regional cooperation solution } \\
\text { recommended for Afghanistan }\end{array}$ \\
\hline 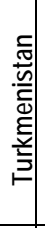 & $\begin{array}{l}\text { 1) Concern for Afghan people only. 2) Little } \\
\text { evidence of regional security concern }\end{array}$ & $\begin{array}{l}\text { 1) Least cooperative with U.S./NATO efforts in Afghan } \\
\text { 2) Humanitarian assistance } \\
\text { 3) Provides electricity, and cancelled previous Afghan } \\
\text { debt for Turkmen electricity } \\
\text { 4) No foreign military bases allowed on territory } \\
\text { 5) Promote TAPI gas pipeline } \\
\text { 6) Ineffective implementation of UNODC programs }\end{array}$ & $\begin{array}{l}\text { 1) Provide free electricity } \\
\text { 2) Provide LNG gas } \\
\text { 3) Provide humanitarian aid } \\
\text { 4) Pursue TAPI pipeline construction }\end{array}$ & $\begin{array}{l}\text { BI-LATERAL } \\
\text { Non-compliant with IO's or security } \\
\text { alliances }\end{array}$ \\
\hline 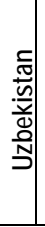 & $\begin{array}{l}\text { 1) Highly sensitive to Islamic Extremism } \\
\text { 2) Increasing threat from IMU, IJU, HUT } \\
\text { relocating N. Afghan }\end{array}$ & $\begin{array}{l}\text { 1) Early partner of ISAF in leasing K2 airbase to } \\
\text { U.S./NATO \& Termez military base to Germans } \\
\text { 2) Financial aide for infrastructure } \\
\text { 3) Construct/manage Rail way for NDN transport of } \\
\text { non-military goods into Afghanistan } \\
\text { 4) } 24 \text {-hr elect. power line construct } \\
\text { 5) Overflight rights for ISAF }\end{array}$ & $\begin{array}{l}\text { 1) Maintain electr. power support } \\
\text { 2) Maintain railway into Afghan } \\
\text { 3) Support U.S. efforts in sustain NDN and } \\
\text { drawdown of equip \& personnel from Afghan }\end{array}$ & $\begin{array}{l}\text { BI-LATERAL } \\
\text { Multi-lateral engagements highly } \\
\text { inconsistent }\end{array}$ \\
\hline
\end{tabular}




\begin{tabular}{|c|c|c|c|c|c|c|}
\hline & \multicolumn{4}{|c|}{ CAPACITY } & \multirow{2}{*}{$\begin{array}{c}\text { UMTATIONS } \\
\text { Limiting Factors }\end{array}$} & \multirow{2}{*}{$\begin{array}{c}\text { FUTURE OUTLOOK } \\
\text { Planned Approach toward Afghanistan } \\
\text { post } 2014\end{array}$} \\
\hline & Economy & $\begin{array}{l}\text { Security Force } \\
\text { Capacity }\end{array}$ & Armed Forces Capacity & $\begin{array}{l}\text { Foreign Policy } \\
\text { Dynamics }\end{array}$ & & \\
\hline 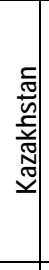 & $\begin{array}{l}\text { 1) Best in region } \\
\text { 2) Industrially } \\
\text { developed } \\
\text { 3) Good use of natural } \\
\text { resources }\end{array}$ & $\begin{array}{l}\text { Relies on Russia for } \\
\text { economic and } \\
\text { regional security } \\
\text { support }\end{array}$ & $\begin{array}{l}\text { Heavily relies on and } \\
\text { Actively partakes in } \\
\text { regional organization } \\
\text { training exercises } \\
\text { (CSTO, SCO) }\end{array}$ & $\begin{array}{l}\text { 1) Balanced policy with } \\
\text { West and Russia } \\
\text { 2) Russia is necessary } \\
\text { for security in region } \\
\text { 3) Relations with CA } \\
\text { neighbors vary greatly }\end{array}$ & $\begin{array}{l}\text { 1) Corruption infiltrates all of Kazakh } \\
\text { society- executive, judicial, military, etc. } \\
\text { 2) High corruption prevents effective } \\
\text { counter-narcotic efforts } \\
\text { 3) Diverse degrees of cooperation with } \\
\text { other CA states }\end{array}$ & $\begin{array}{l}\text { DEFENSIVE } \\
\text { 1) Favors "Security Belt" approach } \\
\text { against negative spillover instability } \\
\text { affects, } \\
\text { 2) Protection is necessary against } \\
\text { northward bound insurgency or narcotics } \\
\text { 3) Socio-Economic development } \\
\text { keystones in its projected aide }\end{array}$ \\
\hline 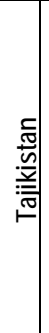 & $\begin{array}{l}\text { 1) Poorest in region } \\
\text { 2) Majority live in } \\
\text { poverty } \\
\text { 3) Highly dep. on Intl } \\
\text { funding } \\
\text { 4) Thousands are } \\
\text { migration workers }\end{array}$ & $\begin{array}{l}\text { 1) KOGG largely } \\
\text { ineffective } \\
\text { 2) Under-funded } \\
\text { 3) Poorly trained } \\
\text { 4) Poorly equipped } \\
\text { 5) Under-manned } \\
\text { 6) Heavily reliant on } \\
\text { RU instruction and } \\
\text { support }\end{array}$ & $\begin{array}{l}\text { 1) Poor leadership } \\
\text { 2) Poor Discipline } \\
\text { 3) Under-funded } \\
\text { 4) Low morale } \\
\text { 5) Slow military reform } \\
\text { 6) Heavily relies on } \\
\text { Russian-led CSTO\& } \\
\text { SCO } \\
\text { 7) CSTO CTOF and RU } \\
\text { military supplements }\end{array}$ & $\begin{array}{l}\text { 1) Heavily reliant on } \\
\text { Russia for economic and } \\
\text { security needs } \\
\text { 2) Respects OSCE and } \\
\text { Western affiliation } \\
\text { 3) Relations depend on } \\
\text { best security and } \\
\text { economic benefits to } \\
\text { Tajikistan }\end{array}$ & $\begin{array}{l}\text { 1) Repressive regime instigates } \\
\text { domestic unrest } \\
\text { 2) High corruption prevents effective } \\
\text { counter-narcotic efforts } \\
\text { 3) Poor cooperation with other CA } \\
\text { states }\end{array}$ & $\begin{array}{l}\text { PASSIVE DEFENSIVE } \\
\text { 1) Lessons learned from its civil war make } \\
\text { it prone to advocate lassie-faire style } \\
\text { approach. } \\
\text { 2) Defense against insurgency with } \\
\text { assistance from RU, CSTO, SCO } \\
\text { 3) Assistance through infrastructure } \\
\text { development and electrical power } \\
\text { delivery. }\end{array}$ \\
\hline 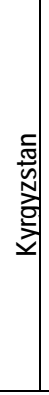 & $\begin{array}{l}\text { 1) One of poorest in } \\
\text { region } \\
\text { 2) Highly dep. on Intl } \\
\text { funding } \\
\text { 3) Highly dep. on } \\
\text { military base leasing } \\
\text { 4) Depleting water } \\
\text { resources for hydro- } \\
\text { electric exports }\end{array}$ & $\begin{array}{l}\text { 1) Limited } \\
\text { Centralized Control } \\
\text { 2) Still recovering } \\
\text { fromethnic conflicts } \\
2010 \\
\text { 3) Ineffective and } \\
\text { corrupt Drug Control } \\
\text { Agency } \\
\text { 4) Dependent on } \\
\text { RU Military aid }\end{array}$ & $\begin{array}{l}\text { 1) Notably weak } \\
\text { 2) Majority conscripts } \\
\text { unfit for senvice } \\
\text { 3) Under-funded } \\
\text { 4) Ill-equipped } \\
\text { 5) Slow military reform } \\
\text { 6) Focused internally vs. } \\
\text { externally } \\
\text { 7) Heavily reliant on EXT } \\
\text { support (RU, U.S., } \\
\text { CSTO, CSO) }\end{array}$ & $\begin{array}{l}\text { 1) "Chaotic" Multi- } \\
\text { Vectored to leverage } \\
\text { political interests \& } \\
\text { obtain maximum } \\
\text { financial and security } \\
\text { benefits from both RU \& } \\
\text { U.S. } \\
\text { 2) RU \& U.S. military } \\
\text { base support } \\
\text { 3) hosts RU-led CSTO } \\
\text { rapid reaction forces } \\
\text { 4) Limited coop w/ CA }\end{array}$ & $\begin{array}{l}\text { 1) Political infighting remains within } \\
\text { newly formed Parliamentary govt } \\
\text { 2) Ineffective narcotics control } \\
\text { 3) High corruption and org. crime } \\
\text { 4) Lack of focus externally } \\
\text { 5) Poor economic condition }\end{array}$ & $\begin{array}{l}\text { DEFENSIVE } \\
\text { 1) MFA hoping for regional approach } \\
\text { supported with bi-lateral engagements } \\
\text { 2) Training Afghan officers for better } \\
\text { security }\end{array}$ \\
\hline
\end{tabular}




\begin{tabular}{|c|c|c|c|c|c|c|}
\hline 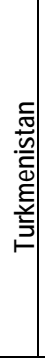 & $\begin{array}{l}\text { 1) Slowest former } \\
\text { Soviet state in econ } \\
\text { reform } \\
\text { 2) Very reliant on gas } \\
\text { revenues } \\
\text { 3) Lacks INTL } \\
\text { assistance }\end{array}$ & $\begin{array}{l}\text { 1) Low prestige } \\
\text { 2) Highly corrupt } \\
\text { 3) Drug Control } \\
\text { ineffective } \\
\text { 4) Poorly manned } \\
\text { 5) Ill-equipped } \\
\text { 6) Ineffective } \\
\text { implementation of } \\
\text { UNODC programs }\end{array}$ & $\begin{array}{l}\text { 1) Notably weakest in CA } \\
\text { region } \\
\text { 2) Untrained } \\
\text { 3) Under-funded } \\
\text { 4) Ill-equipped } \\
\text { 5) Slow military reform } \\
\text { 6) Focused internally vs. } \\
\text { externally }\end{array}$ & $\begin{array}{l}\text { 1) Slow reform from } \\
\text { "permanent neutrality" } \\
\text { 2) Relations w/ CAS } \\
\text { hampered by hydro- } \\
\text { politics } \\
\text { 3) No foreign military } \\
\text { bases allowed on } \\
\text { territory } \\
\text { 4) No participation in } \\
\text { EURASEC, CACO, } \\
\text { CSTO, SCO }\end{array}$ & $\begin{array}{l}\text { 1) Repressive regime instigates } \\
\text { domestic unrest } \\
\text { 2) High corruption prevents effective } \\
\text { counter-narcotic efforts } \\
\text { 3) Historically uncooperative with other } \\
\text { CA states } \\
\text { 4) Isolationistic policies have prevented } \\
\text { economic reform or enhanced trade }\end{array}$ & $\begin{array}{l}\text { SOCIO-ECONOMC } \\
\text { 1) TAPI pipeline initiative } \\
\text { 2) Provide Humanitarian Assistance }\end{array}$ \\
\hline $\begin{array}{l}\frac{5}{5} \\
\frac{0}{0} \\
\frac{0}{0} \\
\frac{N}{D}\end{array}$ & $\begin{array}{l}\text { 1) Constrained by lack } \\
\text { of economic reform } \\
\text { 2) Soviet-style } \\
\text { centrally controlled, } \\
\text { yet heavily privatized }\end{array}$ & $\begin{array}{l}\text { 1) Highly } \\
\text { suppressive regime } \\
\text { provides superior } \\
\text { domestic security } \\
\text { 2) Reliant on bi- } \\
\text { lateral RU/U.S. } \\
\text { border guard } \\
\text { training, financing, } \\
\text { and equip. support } \\
\text { 3) Security forces } \\
\text { are primary force as } \\
\text { Armed Forces are } \\
\text { not intl'y projectable }\end{array}$ & $\begin{array}{l}\text { 1) Military Reform in } \\
\text { progress, forces not } \\
\text { projectable for regional } \\
\text { effect } \\
\text { 2) Still reliant on bi- } \\
\text { lateral RU and U.S. } \\
\text { support for training, } \\
\text { financing, and equip } \\
\text { support } \\
\text { 3) Inconsistent with } \\
\text { regional IO's (CSTO, } \\
\text { SCO) }\end{array}$ & $\begin{array}{l}\text { 1) Karimov understands } \\
\text { Uzbek strategic } \\
\text { significance } \\
\text { 2) Multi-vectored to } \\
\text { maximizes potential } \\
\text { gains from external } \\
\text { governments and IO's } \\
\text { 3) "Uzbek path" prevails } \\
\text { in relations w/ other CA } \\
\text { states }\end{array}$ & $\begin{array}{l}\text { 1) Highly repressive "totalitarian" } \\
\text { regime instigates social unrest } \\
\text { 2) Human rights violations highly } \\
\text { criticized by INTL community } \\
\text { 3) High corruption prevents effective } \\
\text { counter-narcotic efforts } \\
\text { 4) Highly protective, uncooperative with } \\
\text { other CA states, border disputes } \\
\text { 5) Uncooperative with regional } \\
\text { organizations (CSTO, SCO) }\end{array}$ & $\begin{array}{l}\text { DEFENSIVE } \\
\text { 1) Protection is necessary against } \\
\text { northward bound insurgency or narcotics } \\
\text { 2) Planned Uzbek military reform } \\
\text { 3) Increase trade and Afghan reliance on } \\
\text { Uzbek electricity }\end{array}$ \\
\hline
\end{tabular}


erative relationships between the governments of all of these countries, furthermore, prohibit consensus on a regional solution to resolve instability in the event of negative transnational effects after 2014. Therefore, a collective Central Asian regional solution to address the security deficiencies in Afghanistan after U.S. and ISAF forces withdraw from Afghanistan is highly unlikely.

Rather, a more collective defensive approach is likely to ensue. As the U.S. and Russia continue to pursue influence in the region through strategic bilateral military aid packages, and Russia persists with multi-lateral efforts through the CSTO and SCO to protect its national security interests, each Central Asian state will continue to rely on these relationships to supplement their security deficiencies and establish a defensive front. Only in the event that promising economic opportunities appear likely will they venture beyond this defense-focused stance. Turkmenistan will continue to pursue its TAPI pipeline, just as Tajikistan will construct its Ramon hydroelectric plant to bring joint economic benefit with Afghanistan. Kazakhstan and Kyrgyzstan will continue providing indirect support through training assistance through the OSCE to restore the social and economic sectors in Afghanistan, but militarily or security force assistance will most likely not be directly provided in the near future.

\section{The Future of Afghanistan and Central Asia's Role}

The future of Afghanistan remains uncertain. While the international community remains publicly committed to the transformation of Afghanistan into a country that respects the rule of law and prospers democratically, many U.S. and UN officials in Kabul concede that in the best-case scenario, Afghanistan will become in two or three decades what most of its Central Asian neighbors are today. This model could resemble Tajikistan, which "is hardly a model of democracy or development. Elections are stacked, positions in the government bought and sold, and crucial public goods and services doled out to regime cronies." ${ }^{87}$ Or, even worse, as some Afghans fear, a civil war will erupt, and the Taliban may return in full force. ${ }^{88}$ The Taliban may be feigning weakness in their force capacities, to wait for the U.S. and coalition force strength to wane in the region. Mohammad Qorban Haqjo even pointed out that the Taliban view the troop withdrawal as a defeat for the foreigners. ${ }^{89}$

The role the Central Asian states will play in Afghanistan after U.S. and NATO/ ISAF forces complete their withdrawal in 2014 has been shown to encompass a more indirect defensive approach. Without radical reform in the Central Asian states' security and armed force capacity, a significant reduction of corruption, and renewed foreign policies that reflect cooperation rather than foster disruption between neighboring

87 George Gavrilis, "The Tajik Solution."

88 Mirwais Khan and Rahim Faiez, "Afghans Anxious About Exit of Foreign Troops," USA Today (2 September 2011); available at www.usatoday.com/news/world/afghanistan/story/ 2011-09-02/Afghans-anxious-about-exit-of-foreign-troops/50234734/1.

89 Abdol W. Faramarz, "Afghan Pullout Blow to Economy," Asia Times Online (25 August 2011). 
governments, any collective solution of intercession in Afghanistan toward a unified regional security goal on the part of the Central Asian states is highly unlikely to succeed. Instead, the countries will continue as they have been, strategically creating a buffer zone of protection against any negative spillover effects resulting from the conflicts that may arise in Afghanistan. These conflicts include incursions from terrorist organizations, drug trafficking, and other forms of organized crime. Furthermore, they will increase their reliance on either bilateral or multi-lateral security relationships with larger superpowers and regional organizations such as the U.S., Russia, or the CSTO and SCO to support their weak military, drug control, and border security organizations, and other deficiencies within their respective security sectors.

Solutions for regional security do not simply fall on the shoulders of Central Asia. Iran, China, Pakistan, India, and other regional actors will play a significant role as well. The UN Secretary-General pointed out during the Third Ministerial Conference of the Paris Pact Partners on Combating the Afghan Illicit Opiate Trade that the international community will look to the UN to shoulder the responsibility for ensuring stability and sustainable development in Afghanistan after the withdrawal of ISAF in 2014. ${ }^{90}$ However, much international cooperation will depend on the outcomes of the 2013 and 2014 parliamentary and presidential elections in Afghanistan, as well as on the results of various related economic and security transitions that are currently evolving. Whether the newly elected leadership of Afghanistan will put forth a hostile or cooperative foreign policy will determine the level of cooperation and security contributions - financial or otherwise - that it can hope to gain through its diverse bilateral or multi-lateral partnerships.

90 AKIpress News, "UN Secretary General, Foreign Minister Kazakbaev Discuss Reconciliation and Regional Issues," ISI Emerging Markets (17 February 2012). 


\title{
Strategic Communication for Security \& National Defense: Proposal for an Interdisciplinary Approach
}

\author{
Cristian E. Guerrero-Castro * \\ $\sum \begin{aligned} & S+S D=(S P . m+I N P+N I)=\left(S^{*}\right)+ \\ & C+S D=(I n f . I n t, D e c l, C o d l, S i g l, P l t\end{aligned}$ \\ $C+S D=(\operatorname{Inf}$, Int,Dec1,Cod1,Sig1,Plt,Dif $)=\left(C^{*}\right)+[I S$, Sec,Def] $=$ S.C.S.N.D
}

\section{Introduction}

Most recent military actions have provided stark examples of the increasing power of communications in the public and governmental arena regarding the role that direct actors play in disputes characterized as "conflicts of interests." These examples have also shown how communications can directly influence perceptions within the international system and among those who enjoy "freedom of action," who are always pursued by an arsenal of immediate media technology. However, in a conflict of interests, nation-states act along political lines and use the tools of the "fields of action" (internal, external, economic, and defense) to execute their national strategies, with the objective of maintaining or pursuing political and strategic objectives. But how can we defend ourselves against communications, or use them to benefit our political-strategic interests?

After the terrorist attacks of September 2001, three capabilities concerning communication began to develop within the George W. Bush Administration in the U.S.: "Information Operations and Psychological Operations" (IO and PSYOPS); "Public Affairs" (PA); and "Defense Support to Public Diplomacy" (DSPD). This was done by dedicating integrated communications technologies for use in pursuing specific tactics, operations, and other elements of the national strategy in this so-called "war of perceptions," with the objective of achieving credibility and thus freedom of action. In that moment the concept of "strategic communication" started to appear in the vocabulary of many people linked to security and national defense issues.

Between 2002 and 2004, after many reports, studies, and drafts of the definition of strategic communication in the area of defense, the concept migrated to other areas such as business, public relations, and social communication, generating dissonance

* Cristian E. Guerrero-Castro holds a Licentiate in Social Communication and a Master's in Strategic Communication; he graduated from the National Academy of Political and Strategic Studies at the Ministry of Defense in Chile with a post-graduate degree in Political and Strategic Studies and a Master's in Security and Defense. He graduated from the CHDS at the National Defense University of USA with the specialty of "Strategy and Defense Policy." In 2013, he participated in the "CBR-Nuclear Defense Course" at the NATO School in Germany. He is currently working as researcher and acting managing editor of the PTSS at the George C. Marshall European Center for Security Studies in Garmisch-Partenkirchen, Germany. 


\title{
THE QUARTERLY JOURNAL
}

within the concept. Meanwhile, another concept, called "strategic communications" (the only difference being the "s") was born, causing even more confusion.

This article intends to offer an interdisciplinary approach to strategy and mass communication in the field of security and national defense and to define, by means of hermeneutical, qualitative, and quantitative research techniques, the definitions, missions and lineaments of strategic communication. It will create a model proposal for "Strategic Communication for Security and National Defense," with the objective of tracing the guidelines of this vital tool for pursuing and maintaining permanent national objectives, including peacekeeping. We will begin with a look at this concept, its evolution and attempts of definitions in recent years.

\section{The Evolution of the Definition of Strategic Communication}

The Report of the Defense Science Board Task Force on Strategic Communication in the year 2004 defined strategic communication as follows:

\begin{abstract}
Strategic communication is a vital component of U.S. national security. It is in crisis, and it must be transformed with a strength of purpose that matches our commitment to diplomacy, defense, intelligence, law enforcement, and homeland security. Presidential leadership and the bipartisan political will of Congress are essential. Collaboration between government and the private sector on an unprecedented scale is imperative. ... Moreover, strategic communication efforts must reinforce key themes and messages and constantly be measured against defined objectives. As a result, adjustments must be made and those responsible for implementation held accountable. ${ }^{1}$
\end{abstract}

This shows that strategic communication "efforts" are a vital component of U.S. national security.

Moreover, in 2005 the Director of Strategic Communications and Information at the National Security Council (NSC), Jeff Jones, pointed out the importance of strategic communication by saying: "There is little evidence of cooperation, coordination, or even more, the appreciation of the impact of strategic communication." 2

Then, at the end of 2006, after a visit to the Pentagon with a delegation of the ANEPE, I read another definition of strategic communication in the "QDR Execution Roadmap for Strategic Communication 2006" that defines strategic communication as communication that "focuses United States Government process and efforts to understand and engage key audiences to create, strengthen, or preserve conditions favorable to advance national interests and objectives through the use of coordinated information, themes, plans, programs, and actions synchronized with other elements of national

1 U.S. Department of Defense, Office of the Under Secretary for Acquisition, Technology, and Logistics, "Report of the Defense Science Board Task Force on Strategic Communication," (Washington, D.C., September 2004); available at http://www.acq.osd.mil/dsb/reports/ ADA428770.pdf.

2 Jeffrey B. Jones, "Strategic Communication: A Mandate for the United States," Joint Force Quarterly 39 (October 2005). 
power." ${ }^{3}$ This provides additional evidence for the fact that strategic communication can be used in pursuit of national interests using the coordination of information, which I refer to as "logic of action." It also clarifies that this coordinated information must be synchronized with other elements of national power.

Subsequently, the National Defense Authorization Act of 2009 called for the creation of a new area for strategic communication. The House Armed Services Committee pointed out its critical importance by saying: "The committee believes the Department should leverage these efforts to designate a science and technology thrust area for strategic communication and focus on critical science and technology opportunities...." 4

Considering the impact of strategic communication, many professionals borrow this concept irresponsibly and create differing definitions and roles for it, attempting to integrate it into many different areas, causing confusion with the result that each public or government entity develops a "strategic communication" plan according to the interpretation of whoever is in charge. Often these efforts are simply carrying out social communication, or even marketing, which is often confusing, or wrong. So, the following questions have emerged:

- What is strategic communication?

- What is strategic communication for security and national defense?

- When is communication strategic?

Later, in 2010, the White House Strategic Communications Report to Congress declared:

Over the last few years, the term "strategic communication" has become increasingly popular. However, different uses of the term "strategic communication" have led to significant confusion. As a result, we believe it is necessary to begin this report by clarifying what we mean by strategic communication. By "strategic communication(s)" we refer to: (a) the synchronization of words and deeds and how they will be perceived by selected audiences, as well as (b) programs and activities deliberately aimed at communicating and engaging with intended audiences, including those implemented by public affairs, public diplomacy, and information operations professionals. ${ }^{5}$

After many years of confusion, last year, the National Defense Authorization Act of 2012 changed the concept of strategic communication that they mentioned before to strategic communications by declaring: "The committee continues to support information operations (IO) and strategic communications (SC) as important tools for coun-

3 U.S. Department of Defense, "Quadrennial Defense Review_Execution Roadmap for Strategic Communication 2006," (Washington, D.C., September 2006); available at www.dtic.mil/dtic/tr/fulltext/u2/a495367.pdf.

4 U.S. House of Representatives Armed Services Committee, "Report on H.R. 5658 [the National Defense Authorization Act for Fiscal 2009]," (Washington, D.C., 16 May 2008); available at www.dtic.mil/congressional_budget/pdfs/FY2009_pdfs/HASC_110-652.pdf.

5 White House Strategic Communications Report to Congress, Released March 17, 2010. 


\section{THE QUARTERLY JOURNAL}

tering enemy narratives, as well as engaging with the global community." 6 Therefore, strategic communication is seen as something that should be used in support of national interests and synchronized with national power.

\section{The Problems}

At this point, we have a general idea about the subject and goals of this article, but to understand the phenomenon of study we must first delve into the current qualitative problems concerning the confusion that exists about the definition of strategic communication.

\section{Strategic Communication?}

In the post-9/11 era, strategic communication has become a term used for more than a hundred disciplines, pseudo-disciplines, and professions. It is deployed as a recurrent and helpful concept to indicate that a project involves smart thinking, planning, and coordination, and is ruthlessly used for marketing, business, public relations, and many other areas. But does strategic communication mean the same thing in these various fields? How can those areas develop strategic communication? Does the concept even make sense in all these areas?

So what happens when we try to speak of strategic communication in the area of security and national defense? Are we referring to public relations, journalism, diplomacy, military diplomacy, telecommunications, propaganda, or efforts to shape a country's image? Perhaps it relates to the coordination of internal and external communications of public, state, and government institutions? Or it is simply government marketing? What happens when the nation must act or react to a scenario where communications are vital to support permanent national objectives? What kind of strategic communication should be used, and according to the definition of which profession should it be executed? As was noted above, each government, ministry, department, institution, or entity develops its own approach to strategic communication, defined by the professional who is in charge, which results in the confusing proliferation of the application of the term to situations where it is not appropriate. As Professor Rosa Brooks correctly notes, "[There is] no question in my mind there are people in the name of U.S. government strategic communications doing stupid things right this minute." 7

6 Report of the House Armed Services Committee on the National Defense Authorization Act for Fiscal Year, 2012.

7 "Ten Years On: The Evolution of Strategic Communication and Information Operations since 9/11: Hearing before the Subcommittee on Emerging Threats and Capabilities of the Committee on Armed Services House of Representatives," 112 Cong. (H.A.S.C. No. 112-49, 12 July 2011); available at http://www.gpo.gov/fdsys/pkg/CHRG-112hhrg67796/pdf/CHRG112hhrg67796.pdf. 


\section{Strategic Communication or Social Communication?}

Let me include a personal experience in relation to the previous question. In 2006 during a visit to Washington D.C., I had the opportunity to meet with two professionals involved in the use of communications in the area of security and national defense. They were a journalist in charge of the internal and external communications of a government agency, and an official of the General Staff in charge of command communications. When I asked them what was the mission of communications in the area of security and national defense, the journalist immediately said that it was not just communication, but it was "strategic communication," and that the mission was to integrate the broader society with the armed forces. Then the official of the General Staff told me that the missions of communication for security and defense were to coordinate the forces, gather information, and create intelligence. It was also involved with social communication, or public relations, with the primary objective of informing the civilians about the role of the armed forces in peacetime, with the appropriate compartmentalization of information under high command supervision.

The official clearly (and correctly) referred to some of the missions of the strategic dimension of communication and the intelligence process, and then to the activities of social communication and public relations. But where is the strategy that the journalist told me about? Nowhere, of course. What she called "strategic communication" is nothing more than public relations based on social communication. Why is this not strategic? Because this type of communication neither works in the strategic dimension nor pursues any vital objective of the nation-state. Strategy focuses attention on how to articulate the tools for achieving goals related to dealing with threats that lead to conflicts, and furthermore, it recognizes that the means employed must be coordinated at the highest level of the nation-state and must also understand the broad spectrum of all the resources that constitute national power. Or, as Professor Harry Yarger said in his definition of strategy and its objectives (state interests): "Strategy is all about how (way or concept) leadership will use the power (means or resources) available to the state to exercise control over sets of circumstances and geographic locations to achieve objectives (ends) that support state interests. Strategy provides direction for the coercive or persuasive use of this power to achieve specified objectives" 8

The discussion that I related above ended when the journalist began to refer to "the operative strategy" and "the tactical strategy." In that moment, the official of the General Staff and I looked at each other and decided to gently end the discussion and to assent to what the journalist said. But it caught my attention that a journalist in charge of the area of social communication of a defense agency so flagrantly confused the strategic, operative, and tactical dimensions, mixing them without any shame. Two years after that, when I was again in the United States, I had a conversation with an accomplished professional in the national defense sector who said that, while it could not be

8 H. Richard Yarger, "Towards a Theory of Strategy: Art Lykke and the Army War College Strategy Model” (Carlisle: U.S. Army War College, 2008); available at www.au.af.mil/ au/awc/awcgate/army-usawc/stratpap.htm. 


\section{THE QUARTERLY JOURNAL}

referred to as "strategic communication," since it was a process that was still a subject of study that was only being discussed, the mission of social communication in the area of defense was to facilitate communication with the media; this person also spoke of public relations, which had the mission to gain trust, understanding, and support from the public. Therefore, social communication is confused with strategic communication merely due to the fact that the concept or word "strategy" reflects the importance of the role that civilians play in security and national defense.

Later that same year, in a class of "Communication and Strategy for Crisis Simulation Games" for the high command course in Political and Strategic Studies at an academic institution in America, where I was guest lecturer in June 2008, the state officials who were the students in this course asked the following questions: What is strategic about strategic communication? What is the real field of action of strategic communication? Does it belong to business, marketing, advertising, journalism, defense, the state, or is it integrated into all of them? Is there an official, aligned and structured definition of strategic communication for security and national defense? What are the tools that strategic communication uses? What is the mission of strategic communication? Does it have to do with the press releases of the armed forces or the agencies and ministries of defense? Does it have to do with the internal communication of the institutions linked to the area of defense? Is it military diplomacy? Or it is coercive diplomacy? Or perhaps it has to do with telecommunications and communicational coordination of the forces? Without doubt, there are many questions about strategic communication, but so far there seems to be only one answer: The definition of strategic communication is lost in a universe full of ambiguities, confusions, and conceptual gaps.

However, does this mean that it is impossible to know what strategic communication is, what its qualities and missions are? These statements make the use of communications as a vital tool evident, but when we are talking about strategic communication we attribute it to many disciplines and pseudo-disciplines, thus creating confusion that prevents us from understanding and working with this instrument. Hence, this article is based on the results of an interdisciplinary approach between Strategic Studies and Mass Communication in the field of security and national defense. As was stated above, it attempts to provide a definition, missions, and lineaments for strategic communications, and creates a model proposal for "Strategic Communication for Security and National Defense," with the objective of tracing the guidelines of this vital tool for pursuing and maintaining permanent national objectives, including peacekeeping.

\section{Methods}

It needs to be mentioned that this article aims to deliver to professionals in the academic and political-military area, simply and clearly, the results of a hermeneutic qualitative-quantitative research study through an interdisciplinary approach between the "models of strategy" of Beaufre $(1965)$ " and the "models of communication" of

\footnotetext{
9 Andre Beaufre, “An Introduction to Strategy” (New York: F. Praeger, 1965).
} 
Laswell (1948) ${ }^{10}$, Berlo (1960) ${ }^{11}$, Schramm (1954) ${ }^{12}$, Shannon $(1948)^{13}$ and Maletzke (1963) ${ }^{14}$ models selected by results of a selection criteria matrix. These have been integrated into the definitions of "National Security Strategy" and "National Defense Strategy" by analytical instruments designed for this research in order to identify and justify pertinent concepts and develop proposals for the definition, lineaments, missions and model of strategic communication for security and national defense.

Design

This research created five instruments using hermeneutic, qualitative, and quantitative methods for the interdisciplinary approach by analyzing the objects of study and the inductive codes (see Table 1).

Table 1: Study Instruments.

\begin{tabular}{|l|l|}
\hline $\mathbf{1}$ & Instruments \\
\hline SCA & Selection criteria analysis \\
$H A M$ & Hermeneutic analysis matrix \\
Q-QAM & Qualitative-quantitative analysis matrix \\
HDM & Hermeneutic definition matrix \\
IHDM & Integral hermeneutic definition matrix (interdisciplinary approach) \\
\hline $\mathbf{2}$ & Objects of study \\
\hline M.S & Models of Strategy of Beaufre (1975) \\
M.C & Models of Communication of Laswell (1948), Berlo (1960), Schramm \\
D.NSS & (1954), Shannon (1948) and Maletzke (1963) \\
D.NDS & Definition of National Security Strategy of DoD \\
\hline $\mathbf{3}$ & Definition of National Defense Strategy of DoD \\
\hline C.S & Inductive codes \\
C.C & Concepts of Strategy \\
C.SND & Concepts of Communication \\
\hline
\end{tabular}

10 Harold D. Lasswell, "The Structure and Function of Communication in Society," in Lyman Bryson, ed., The Communication of Ideas (New York: Harper \& Bros., 1948).

11 David K. Berlo, The Process of Communication (New York: Holt, Rinehart, \& Winston, 1960).

12 Wilbur Schramm, The Process and Effects of Mass Communication (Urbana: University of Illinois Press, 1954).

13 Claude E. Shannon, A Mathematical Theory of Communication (New York: Bell System Technical Journal, 1948).

14 Gerhard Maletzke, Psychologie der Massenkommunikation; Theorie und Systematik (Hamburg: Hans Bredow-Institut, 1963). 


\section{Thesis}

The definition, lineaments, missions, and model of strategic communication for security and national defense should integrate the concepts of strategy, concepts of communication, and concepts of national security and defense in order to communicate strategically and achieve the national objectives and national interest of a nation-state.

\section{Specific Objectives}

In addition to the general objectives outlined above, this study has several specific objectives:

1. To identify the relevant concepts of strategy (C.S) by analyzing the models of strategy (M.S) of Beaufre using a hermeneutic analysis matrix (HAM).

2. To identify the relevant concepts of communication (C.C) by analyzing the models of communication (M.C) of Laswell (1948), Berlo (1960), Schramm (1954), Shannon (1948), and Maletzke (1963) using a hermeneutic analysis matrix.

3. To identify the relevant concepts of security and national defense (C.SND) by analyzing the definitions of "National Security Strategy" and "National Defense Strategy" employed by the U.S. Department of Defense using a hermeneutic analysis matrix.

4. To verify the relevant model of strategy for the interdisciplinary approach by using a qualitative-quantitative analysis matrix (Q-QAM) of the models of strategy and concepts of communication.

5. To verify the relevant model of communication for the interdisciplinary approach by using a qualitative-quantitative analysis matrix of the models of communication and concepts of strategy.

6. To develop a definition of strategy based on the results of the hermeneutic definition matrix (HDM) of concepts of strategy and concepts of security and national defense.

7. To develop a definition of communication based on the results of the hermeneutic definition matrix of concepts of communication and concepts of security and national defense.

8. To develop a definition of strategic communication for security and national defense based on the results of the integral hermeneutic definition matrix (IHDM) of concepts of strategy, concepts of communication, and concepts of security and national defense.

9. To explore the lineaments of strategic communication for security and national defense based on the results of the hermeneutic analysis matrix.

10. To explore the missions of strategic communication for security and national defense based on the results of the hermeneutic analysis matrix.

11. To design and propose a model of strategic communication for security and national defense as final result of this research. 


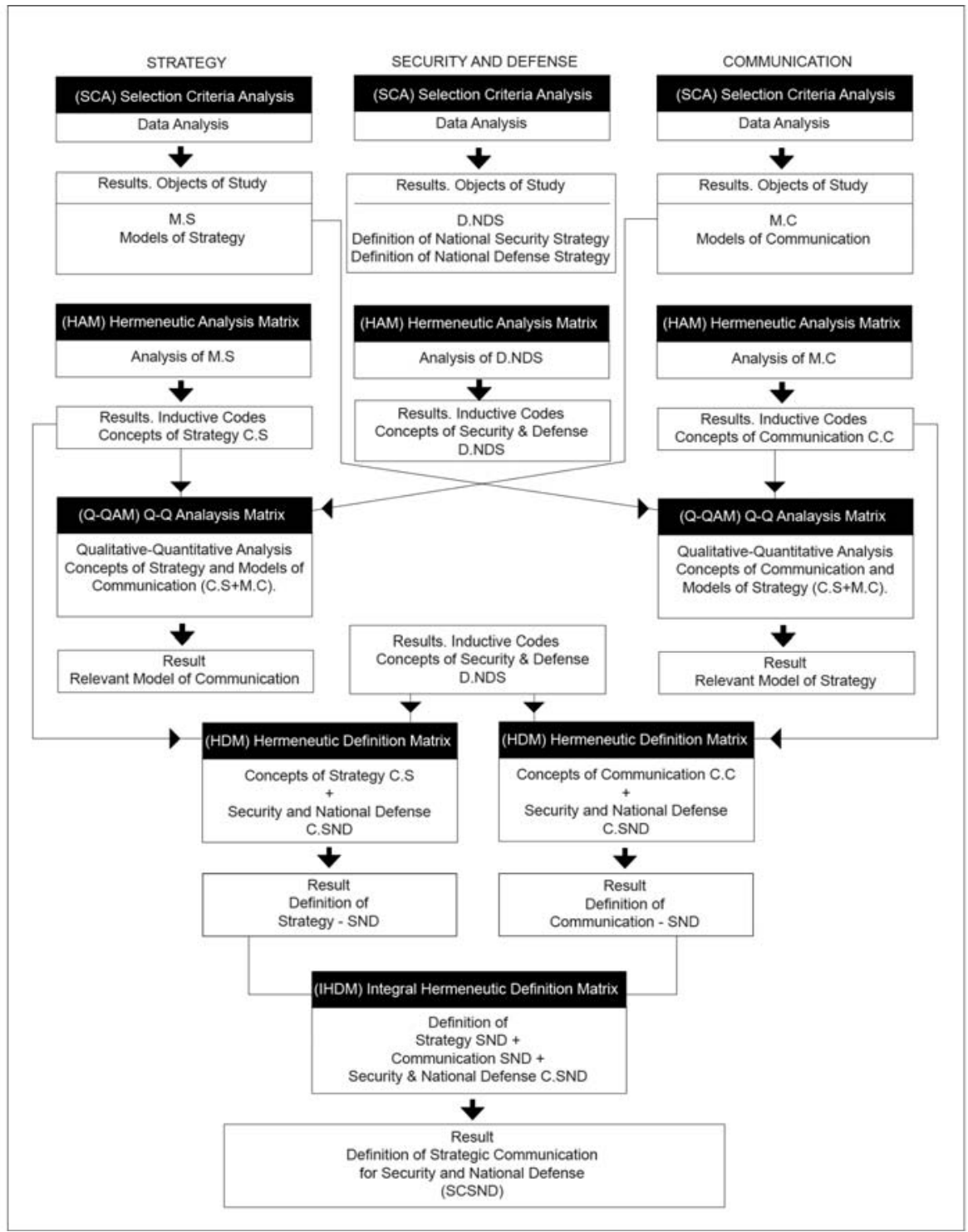

Figure 1: Research Process of Definition. ${ }^{15}$

15 This figure shows the instruments of: Selection Criteria Analysis; Hermeneutic Analysis Matrix; Qualitative-Quantitative Analysis Matrix; Hermeneutic Definition Matrix; and Integral Hermeneutic Definition Matrix. 


\section{Process}

The process of this research was divided into eight phases:

1. Selection criteria analysis (SCA) of models of strategy and models of communication and definitions of "National Security Strategy" and "National Defense Strategy."

2. Hermeneutic analysis matrix of models of strategy and models of communication and definitions of "National Security Strategy" and "National Defense Strategy."

3. Qualitative-quantitative analysis matrix of models of strategy and models of communication and definitions of "National Security Strategy" and "National Defense Strategy."

4. Hermeneutic definition matrix of concepts of strategy and concepts of security and national defense.

5. Hermeneutic definition matrix of concepts of communication and concepts of security and national defense.

6. Integral hermeneutic definition matrix of definitions of strategy, communication, and security and defense.

7. Hermeneutic analysis matrix of the relevant model of strategy, the relevant model of communication, and the definition of strategic communication for security and national defense created in this research.

8. Design and propose a model for strategic communication for security and national defense.

\section{Results}

According to the instruments of this research (selection criteria analysis, hermeneutic analysis matrix, qualitative-quantitative analysis matrix, hermeneutic definition matrix, and the Integral hermeneutic definition matrix), this research approves the thesis with the following results.

\section{Selection Criteria}

- Results of the selection criteria analysis (models of strategy). The models of strategy (object of study) in this research are: Beaufre's models; direct threat model; indirect pressure model; total vs low military intensity model; successive action model; and violent military victory model.

- Results of the selection criteria analysis (models of communication). The models of communication (object of study) in this research are: Laswell's model; Berlo's model; Schramm's model; Shannon's model; and Maletzke's model (see Figures 2 and 3). 
Figure 2: Selection Criteria (Models of Strategy). ${ }^{16}$

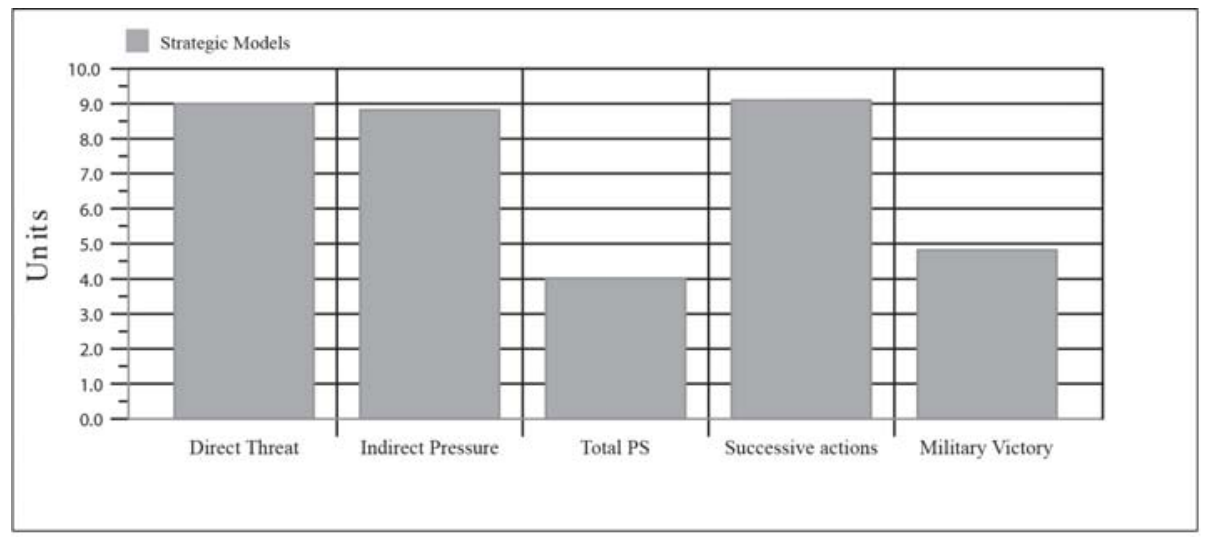

$\sum f_{10}^{0.100}[M . S+C . C]+$ SuccAct, $M=9.10$

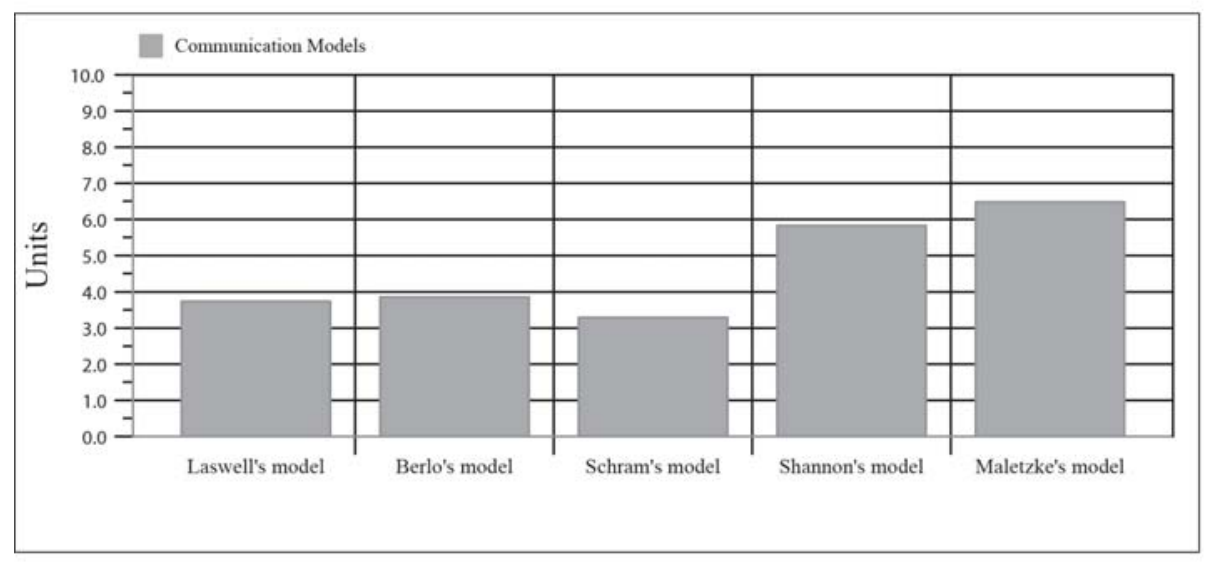

$\sum f_{10}^{0.100}[$ M.C $+C . S]=$ Maletzke, $M=6.486$

Figure 3: Selection Criteria (Models of Communication). ${ }^{17}$

16 Relevant Model of Strategy; Successive Actions*= SuccAct, M.

17 Relevant Model of Communication; Maletzke*= Maletzke, M. 


\section{Inductive Codes}

- Results of hermeneutic analysis matrix (concepts of strategy). The relevant concepts of strategy are: national objectives, national interests, national power, strategic dimension, instruments coordination, dissuasion, freedom of action, and legitimacy.

- Results of hermeneutic analysis matrix (concepts of communication). The relevant concepts of communication are: key message, media coordination, information flow, perception, persuasion, stimulus, reaction, and effect.

- Results of hermeneutic analysis matrix (concepts of security and national defense). The relevant concepts of security and national defense are: national power, defense, strategic objectives, armed forces, security, intelligence, national interest, coordination of instruments, peace, conflict, and war.

\section{Qualitative-Quantitative Analysis}

\section{Results of Qualitative-Quantitative Analysis (Concepts of Strategy and Mod- els of Communication)}

The qualitative-quantitative analysis of concepts of strategy (national objectives, national interests, national power, strategic dimension, instruments coordination, dissuasion, freedom of action, and legitimacy) and models of communication is equal to the integration of the concepts of (C.S) + (M.C), which shows as a result that the pertinent model of communication to integrate in this interdisciplinary approach is the model of communication of Maletzke (method based on sender, message, transmission, noise, channel, reception, receiver, and feedback).

The formula in the result explains: The sum of the analysis formula 0.100/10 (set of models of communication and concepts of strategy) equals the model of Maletzke (total of 6.486). (See Table 2)

\section{Results of Qualitative-Quantitative Analysis (Concepts of Communication and Models of Strategy)}

The qualitative-quantitative analysis of concepts of communication and models of strategy is equal to the integration of (C.C) + (M.S), which shows as a result that the pertinent model of strategy to integrate in this interdisciplinary approach is Beaufre's "successive actions" model of strategy (method based on coordinated and successive action of the "direct threat" and "indirect pressure" models).

The formula in the result explains: The sum of the analysis formula 0.100/10 (set of models of strategy and concepts of communication) equals the model of successive actions (total of 9.10) (see Table 3). 
SPRING 2013

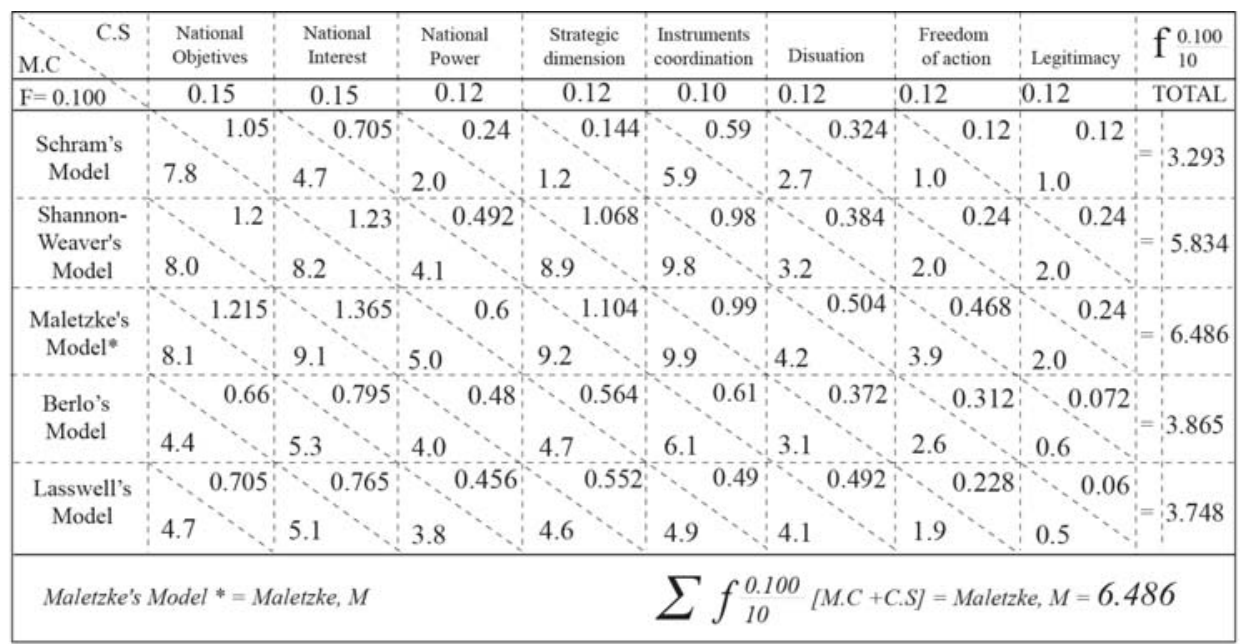

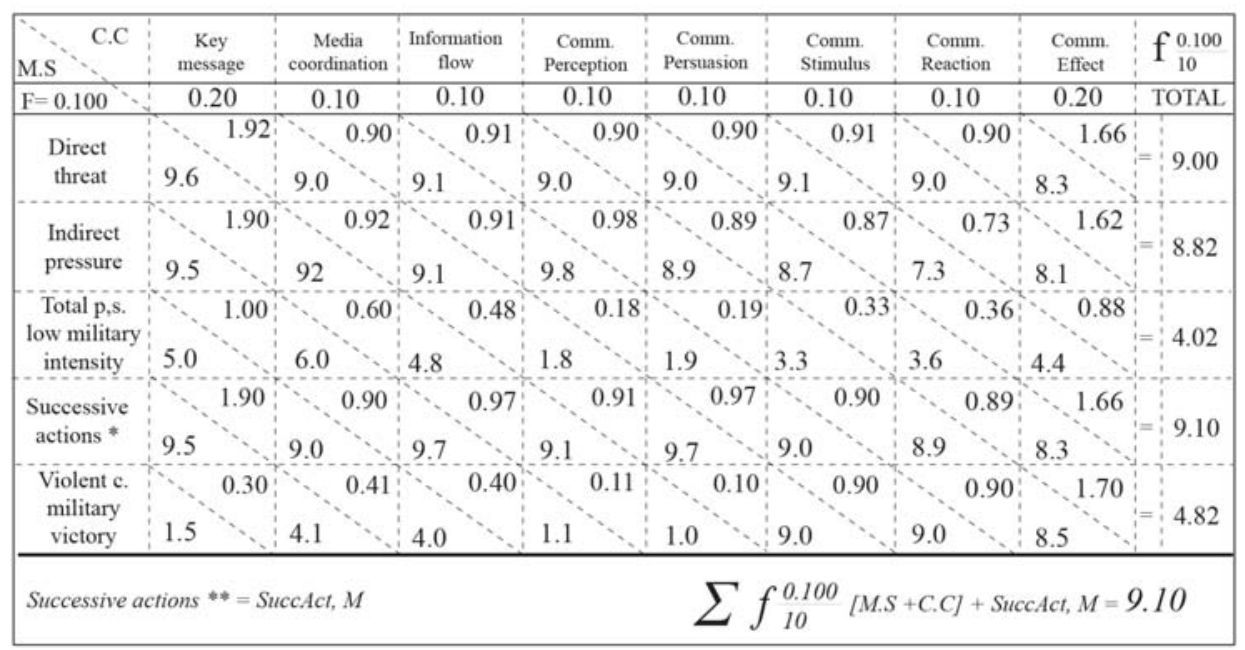

Table 2. Concepts of Strategy and Models of Communication. 


\section{THE QUARTERLY JOURNAL}

\begin{tabular}{|c|c|c|c|c|c|c|c|c|c|}
\hline M.C C.S & $\begin{array}{c}\text { National } \\
\text { Objetives }\end{array}$ & $\begin{array}{l}\text { National } \\
\text { Interest }\end{array}$ & $\begin{array}{c}\text { National } \\
\text { Power }\end{array}$ & $\begin{array}{c}\text { Strategic } \\
\text { dimension }\end{array}$ & $\begin{array}{l}\text { Instruments } \\
\text { coordination }\end{array}$ & Disuation & $\begin{array}{c}\text { Freedom } \\
\text { of action }\end{array}$ & Legitimacy & $\mathrm{f}_{10}^{0.100}$ \\
\hline $\mathrm{F}=0.100$ & 0.15 & 0.15 & 0.12 & 0.12 & 0.10 & 0.12 & 0.12 & 0.12 & TOTAL \\
\hline $\begin{array}{l}\text { Schram's } \\
\text { Model }\end{array}$ & & 4.7 & 2.0 & 1.2 & & 2.7 & 1.0 & $1.0^{0.12}$ & $=3.2$ \\
\hline $\begin{array}{c}\text { Shannon- } \\
\text { Weaver's } \\
\text { Model }\end{array}$ & 8.0 & 8.2 & 4.1 & 8.9 & 9.8 & $\begin{array}{l} \\
3.2\end{array}$ & 2.0 & & 5.834 \\
\hline $\begin{array}{l}\text { Maletzke's } \\
\text { Model* }^{*}\end{array}$ & 8.1 & 9.1 & 5.0 & 9.2 & 9.9 & 4.2 & & 2.0 & 6.4 \\
\hline $\begin{array}{l}\text { Berlo's } \\
\text { Model }\end{array}$ & & 5.3 & & & & & 2.6 & 0.6 & \\
\hline $\begin{array}{l}\text { Lasswell's } \\
\text { Model }\end{array}$ & 4.7 & 5.1 & & & & 4.1 & 1.9 & $\begin{array}{l}0.06 \\
0.5\end{array}$ & \\
\hline Maletzke & del & ke, $M$ & & & $\sum f$ & 00 & S] & $e, M$ & \\
\hline
\end{tabular}

\begin{tabular}{|c|c|c|c|c|c|c|c|c|c|}
\hline M.S C.C & $\begin{array}{c}\text { Key } \\
\text { message }\end{array}$ & $\begin{array}{c}\text { Media } \\
\text { coordination }\end{array}$ & $\begin{array}{l}\text { Information } \\
\text { flow }\end{array}$ & $\begin{array}{c}\text { Comm. } \\
\text { Perception }\end{array}$ & $\begin{array}{c}\text { Comm. } \\
\text { Persuasion }\end{array}$ & $\begin{array}{l}\text { Comm. } \\
\text { Stimulus }\end{array}$ & $\begin{array}{c}\text { Comm. } \\
\text { Reaction }\end{array}$ & $\begin{array}{l}\text { Comm. } \\
\text { Effect }\end{array}$ & $\mathrm{f}_{10}^{0.100}$ \\
\hline $\mathrm{F}=0.100$ & 0.20 & 0.10 & 0.10 & 0.10 & 0.10 & 0.10 & 0.10 & 0.20 & TOTAL \\
\hline $\begin{array}{l}\text { Direct } \\
\text { threat }\end{array}$ & & 9.0 & .1 & 9.0 & & & 9.0 & & 9.00 \\
\hline $\begin{array}{l}\text { Indirect } \\
\text { pressure }\end{array}$ & & 92 & & & & & 73 & & 8.82 \\
\hline $\begin{array}{l}\text { Total p,s. } \\
\text { low military } \\
\text { intensity }\end{array}$ & 5.0 & 6.0 & 4.8 & 1.8 & 1.9 & .3 & 3.6 & 0.88 & 4.02 \\
\hline $\begin{array}{c}\text { Successive } \\
\text { actions * }\end{array}$ & & & & & & 9( & & $\because 1.60$ & 9.10 \\
\hline $\begin{array}{l}\text { Violent } \mathrm{c} . \\
\text { military } \\
\text { victory }\end{array}$ & 1.5 & 4.1 & 4.0 & 1.1 & & .0 & & 8.5 & 4. \\
\hline Succes & & $M$ & & & & 100 & & & .10 \\
\hline
\end{tabular}

Table 3. Concepts of Communication and Models of Strategy. 


\section{Results of the Hermeneutic Definition Matrix (Communication - Security and National Defense)}

The result of the hermeneutic definition matrix of communication in the area of security and national defense in this research is: Communication in the area of security and national defense is the significant message constructed by concepts targeted across a coordinated platform of pertinent media (traditional and non-traditional) so that they can be received by a social collectivity or an entity as a whole, considering scenario factors, direct and indirect actors and thus positioning an image-message and perception in a target group(s) supporting the security and defense objectives of the nationstate. The formula is:

$$
C+S D=(\text { Inf,Int,Decl,Cod1,Sig1,Plt,Dif })=\text { Communication }=\left(C^{*}\right)^{18}
$$

\section{Results of the Hermeneutic Definition Matrix (Strategy - Security and Na- tional Defense)}

The result of the hermeneutic definition matrix of strategy in the area of security and national defense in this research is: Strategy in the area of security and national defense is a science and art that searches through coordinated action logics for a political-strategic decision to serve as the solution to a problem or potential problem, using and coordinating the tools and resources of national power, which were made available in a particular scenario where there are conflicts of interests between two or more actors in order to achieve the national interest. The formula is:

$$
S+S D=(S P . m+I N P+N I)=\text { Strategy }=\left(S^{*}\right)^{19}
$$

\section{Results of the Integral Hermeneutic Definition Matrix (Strategic Communica- tion - Security and National Defense)}

According to the integral hermeneutic definition matrix of strategic communication for security and national defense, the inductive codes are:

1. Communication: key message, media coordination, information flow, perception, persuasion, stimulus, reaction, and effect. $C+S D=($ Inf,Int,Dec1,Cod1,Sig1,Plt,Dif $)=$ Communication $=\left(C^{*}\right)$

2. Strategy: national objectives, national interest, national power, strategic dimension, instruments coordination, dissuasion, freedom of action, and legitimacy.

$$
S+S D=(S P . m+I N P+N I)=\text { Strategy }=\left(S^{*}\right)
$$

${ }^{18} \mathrm{C}+$ SD: communication plus security and national defense; (Inf,Int,Dec1,Cod1,Sig1,Plt,Dif): information, intelligence, decodification, codification, significant message, platforms, diffusion; $\mathrm{C}^{*}$ : communication.

19 S+SD: strategy + security and national defense; (SP.m+INP+NI): strategic-political management plus instruments of national power plus national interest; $\mathrm{S}^{*}$ : strategy. 
3. Security and national defense: national power, defense, strategic objectives, armed forces, security, intelligence, national interest, coordination of instruments, peace, conflict, war, and international system.

[IS,Sec,Def]

If communication in the area of security and national defense is:

$C+S D=($ Inf,Int,Dec 1,Cod1,Sigl,Plt,Dif $)=$ Communication $=\left(C^{*}\right)$, and strategy in the area of security and national defense is: $S+S D=(S P . m+I N P+N I)=$ Strategy $=$ $\left(S^{*}\right)$, the sum of those gives us the following result:

$$
\begin{aligned}
& C+S D=(\text { Inf, Int }, \text { Dec 1,Cod1,Sig1,Plt,Dif })=\text { Communication }=\left(C^{*}\right)+ \\
& S+S D=(S P . m+I N P+N I)=\text { Strategy }=\left(S^{*}\right)=
\end{aligned}
$$$$
\text { Strategic Communication }=(S C)
$$

Therefore, when we integrate the results of communication $=(C *)$, strategy $=\left(S^{*}\right)$, and [IS,Sec,Def] in the equation, the result is:

$$
\begin{aligned}
& C+S D=(I n f, \text { Int,Dec1,Cod1,Sig1,Plt,Dif })=\text { Communication }=\left(C^{*}\right)+ \\
& S+S D=(S P . m+I N P+N I)=\text { Strategy }=\left(S^{*}\right)+[\text { IS,Sec,Def }]=\text { S.C.S.N.D }
\end{aligned}
$$

According to the integral hermeneutic definition matrix, the definition of strategic communication for security and national defense is as follows:

It is the political-strategic management of communication for the security and national defense of a nation-state that searches, analyzes, plans, coordinates, and activates the relevant resources through significant "action logics" (communication action courses) with a significant message constructed according to concepts targeted across a coordinated pertinent platform of media (traditional and non-traditional) in order to achieve a vital objective as solution to a communication problem in a particular scenario (war, crisis, or peace) where there are conflicting wills between other nationstates that interpose with the permanent objectives and/or national interests of one's own nation.

\section{Results of Hermeneutic Analysis Matrix (Lineaments of Strategic Communi- cation for Security and National Defense)}

According to the hermeneutic analysis matrix, strategic communication for security and national defense should participate in the fields of action and support the national strategy through communication to achieve the political-strategic objectives. Consequently, a nation-state has a security and national defense policy with which it activates by means of the fields of action (internal, external, economic, and defense) the mission of achieving and protecting the national interests under pressure and threats.

Therefore, the four fields of action work on the mission of achieving national objectives under pressure and threats, but it is the responsibility of strategic communication to achieve internal and external legitimacy for the action. By obtaining this, the legitimacy of the international system is achieved, and with it freedom of action. 
In conclusion, the lineaments of strategic communication for security and national defense are:

- Pursuing the national interests and the political-strategic objectives of the nation-state

- Working in the political-strategic dimension.

Results of Hermeneutic Analysis Matrix (Mission of Strategic Communication for Security and National Defense)

According to the hermeneutic analysis matrix, the nucleus of the mission of strategic communication for security and national defense is to support the national security strategy and national defense strategy (national strategy) by contributing to maintaining, protecting, and achieving the national interests and objectives of the nation-state.

The mission of strategic communication for security and national defense is divided by temporary states (peace, crisis, and conflict):

- In times of peace, to achieve deterrence in the hemisphere and strategic stature in the international system

- In a state of crisis, to obtain credibility in the international system

- In a state of war, to achieve internal and external legitimacy in the international system in order to obtain freedom of action.

\section{Model Proposal for Strategic Communication for Security and National Defense}

The proposed model of strategic communication for security and national defense integrates the observation and analysis of the scenario called "source of information," where the direct and indirect players and the internal and external target groups (the target groups are the social masses) interact at the point where the conflict of interests is detected. Then the intelligence process develops and decodes useful information (decoding process 1), which is the knowledge required to actualize the pertinent strategic communication from the transmitter entity, which encodes the messages (encoding process 1) and projects them through a platform of media to the social media that decode the information (decoding process 2) and sends it to the target groups, which in turn decode the information (decoding process 3 ) a second time, creating the perception within the international system.

This international system perception is what the strategic communication process uses to achieve credibility, legitimacy, and therefore deterrence and freedom of action, which are vital to support the national strategy and to protect, restore, maintain, and achieve the permanent national objectives and national interests.

\section{Elements of Strategic Communication for Security and National Defense}

Communication Scenario. The communication scenario is the scenario of the international system, in which the following are identified: the conflict of interests, our global 


\section{THE QUARTERLY JOURNAL}

situation, the direct and indirect actors, the internal and external targets, the sources of information, as well as the intervening factors. The international system scenario is the universe of knowledge of the intelligence process, and the intelligence cycle sends the "useful information" to the transmitter who designs the strategic communication.

Conflict of Interests. On the basis of the permanent interests of nation-states, the conflict of interest is the neuralgic point of international relations. The conflict of interests occurs when a nation-state sees its permanent interests threatened by an intention or action of another actor or actors in the international scenario or when two actors have the same interest, leading to a dispute of interests and therefore to a probability of conflict and likely escalation of crisis.

Source of Information. This is the international system divided by: the national information source, the local information source, hemispheric information source, continental information source, supra continental information source, and worldwide information source. The sources of information are the universe of knowledge that uses intelligence to develop useful information for the strategic communication of our nationstate.

Intervening Factors. These are factors that intervene in the communication process that are beyond the control of the actors, and which arise only in the scenario of the international system - for example, natural disasters, political assassinations, or other unexpected events.

Intelligence Process or Intelligence Cycle. This is the process of analyzing the information and transforming it into useful information for the strategic communication process. That can come from open or closed sources of information. It also is the first decoding process.

1. Planning: This is the process through which intelligence requirements, priorities, the methodology to be employed, and the system that will search for information are determined.

2. Search and collection: This phase involves the search for and exploitation of sources of information, whether they are open or closed. The open sources are accessible to the public, while closed sources are those that are confidential or for non-public use.

3. Processing, analysis, and production of information: This is the analysis process of the information obtained by open and closed sources whose methodology allows that information to be transformed into intelligence (useful information).

4. Diffusion: This is the step in which the intelligence process delivers useful information to the transmitter entity depending on the strategy for security and national defense, which then guides the analysis and produces a new intelligence requirement, which activates the intelligence cycle anew.

Transmitter Entity. This is the entity formed by the agencies or offices in charge of strategic communication for security and national defense. It is the entity that creates 
the strategic communication with the media at the disposal of the nation-state, obtains useful information through the intelligence processes, and encodes, plans, coordinates, and distributes the key messages.

Key Message. This is part of the first encoding process, which through a process of analysis and strategic planning creates the vital idea to be positioned in the international system's perception designed by the transmitter entity with the purpose of supporting the national objectives and national interests of the nation-state. The key message changes depending on global situations and the missions of strategic communication:

- In times of peace: to achieve deterrence in the hemisphere and strategic stature in the international system

- In a state of crisis: to obtain credibility in the international system

- In a state of war: to achieve internal and external legitimacy in the international system in order to obtain freedom of action.

Action Logics. These are the logics of the execution procedure of strategic communication, coordinated with the courses of action in the strategic, operative, and tactical dimensions, all of which are synchronized with the key message in the transmitter entities, fields of action, and media platforms that are selected to transmit the key message. The action logics are the joint actions of strategic communication.

Transmitter Entities. These are the agencies, offices, or departments designated in the four fields of action that are coordinated by the transmitter entity. These transmitter entities comply with the diffusion mission of the key message through the selected media platforms.

Media Platforms. These are the channels carrying the key message. They are divided into traditional platforms (e.g., television, radio, newspapers, and others) and non-traditional communication platforms (e.g., Internet, online forums, discussion groups, emails, speeches, parades, contests, events, and others) and are part of the strategic communication planning.

Social Media. These are the communication media that have perception and selfauthority for emission and that are found within our nation-state, in the opponent nation-state, in indirect actors, and therefore in the international system. These media are divided into:

- Traditional social media (analog): News, television, books, articles, propaganda, newspapers, and radio

- Non-traditional social media (digital): Blogs, articles, forums, newsletters, social websites, as well as mobile applications in phones, computers, and many others 
THE QUARTERLY JOURNAL

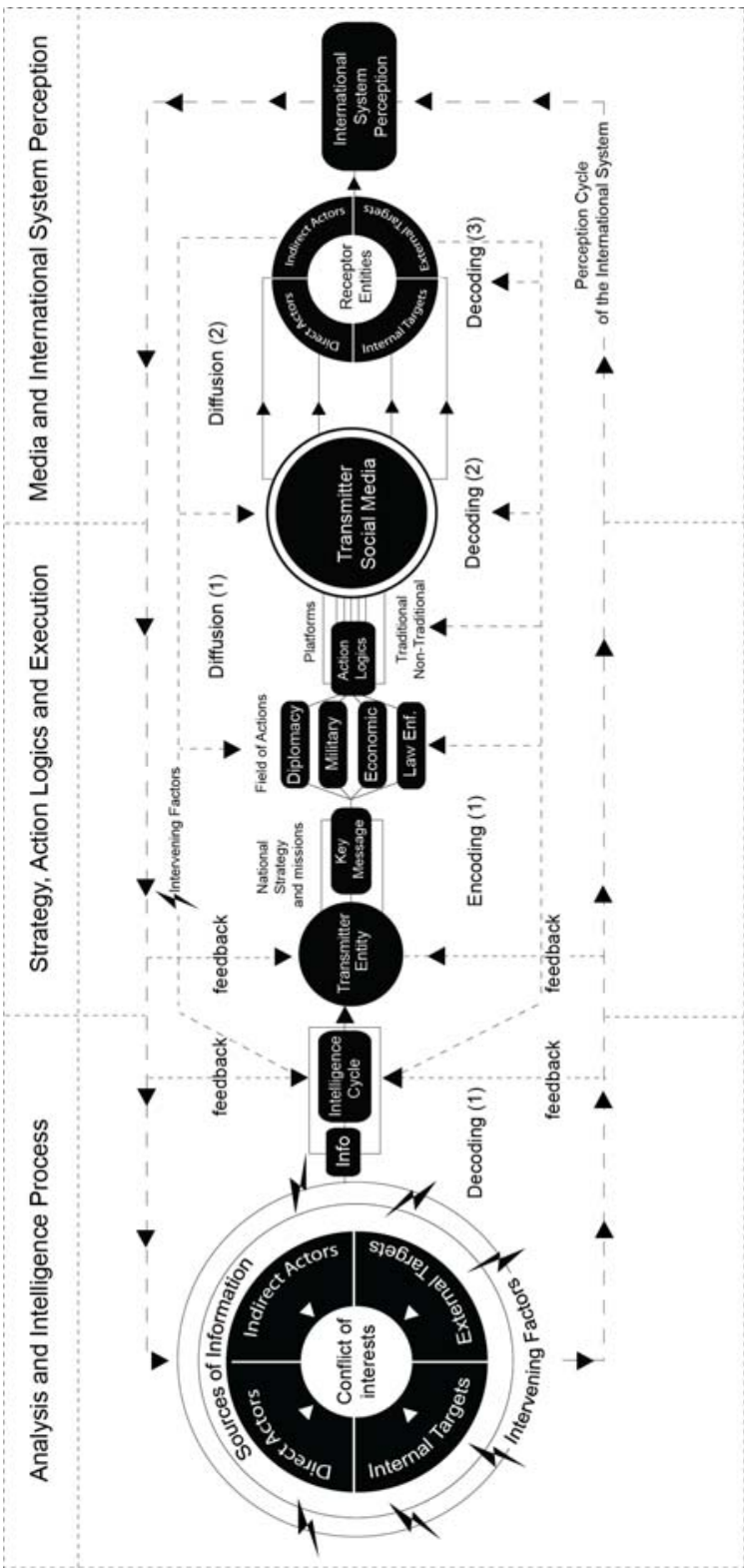

Figure 4: Model Proposal for Strategic Communication for Security and National Defense. $^{20}$

${ }^{20}$ Conflict of interest: (Info+Int), (Dec1,Cod1,Dif1), (Dec2,Dif2,Dec3) = ISP. 
- Activist social media (hybrid): They are those platforms that use traditional and non-traditional social media (analog and digital), including protests, news, speeches, parades, and many others.

Social media decode the transmitted message, and then transmit the message a second time with a new decoding process with intervening factors of the scenario.

Target Groups. These are divided into direct and indirect target groups, which are segments of the populace to whom the message is sent and who decode the message a second time, absorbing the conceptualizations targeted by the strategic communication effort.

Actors. These are divided into direct actors and indirect actors. Direct actors are those actors who interact directly with the problem of conflicts of interests (other nation-states or international organizations), and the indirect actors are those who are of importance even though they are not playing a leading role in the problem. It is these groups that create the international system perception.

International System's Perception is the set of target groups that is also under the influence of intervening factors and that receives and interprets messages through an idea or sensation that results in the material impression in opinions. These opinions create the perception, and these perceptions are those from which the credibility of the nation-states - and therefore their legitimacy and possible freedom of action-originates, activating the cycle of the international system perception.

This model is a proposal for the logical process of strategic communication for security and national defense based on the results obtained by the methodological integration of communication, strategy, and security and national defense using the hermeneutic-qualitative-quantitative research method (see Figure 4).

\section{Conclusions}

\section{About the Interdisciplinary Approach}

The integration of Beaufre's "successive actions" strategy model and Maletzke's model of communication with the definitions of "National Security Strategy" and "National Defense Strategy" was successfully achieved. This integration resulted in a clean and structured interdisciplinary approach that integrates the processes of strategy and communication, which were integrated under the lineaments, missions, and objectives of security and national defense (see Figure 5).

Subsequently, based on the five instruments of analysis that were designed as part of this research, the construction of the definitions of "strategy" and "communication" in the area of security and national defense, as well as the definition of "strategic communication for security and national defense," was achieved.

\section{About Strategy}

First, I need to say that strategy is a science and discipline that is unique among the political and military sciences. Strategy is always connected to the vital objectives and 


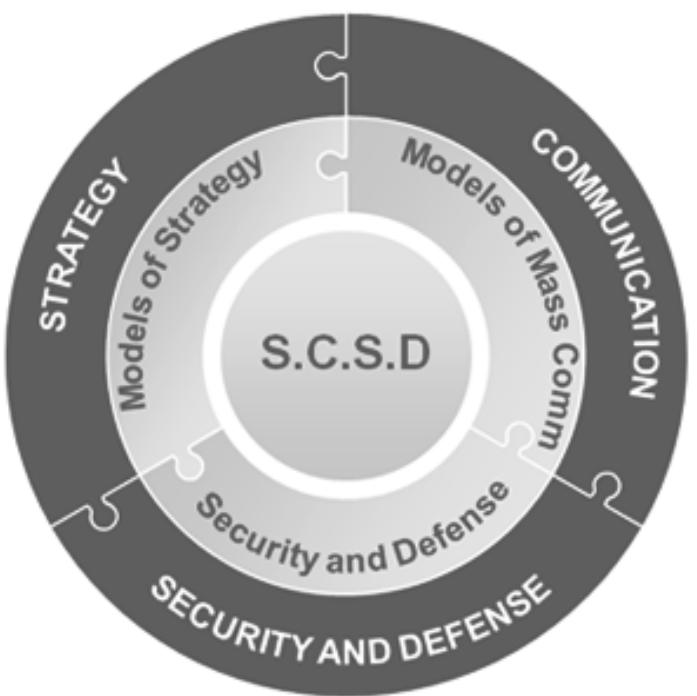

Figure 5: Interdisciplinary Approach.

interests of a nation-state. This has been the case from antiquity, with Thucydides and Xenophon, through to Clausewitz, Liddell Hart, Beaufre, and many other strategists.

Based on the selection criteria and qualitative research process, I can say with absolute certainty and clarity that a "real strategy process" is never found in the field of medicine, education, engineering, psychology, marketing, or any other discipline or pseudo-discipline. This is because they are not working with the resources or powers of the nation-state, and do not pursue national political-strategic objectives or national interests, and therefore are not vital for a nation-state.

Strategy in the area of security and national defense occurs only in the strategic or political-strategic dimensions of a nation-state. If the discipline, profession, pseudodiscipline, craft, or activity that wants to be called "strategic" does not lie within these dimensions, and its mission is not to support the political-strategic objectives of a nation-state, it is not strategic.

\section{About the Definition Problem of Strategy}

This hijacking of the concept results in clumsy rearrangements and clumsy rhetorical configurations that confuse tactics with maneuvers, maneuvers with operations, tactics with strategy, strategy with maneuvers, etc. Its use is purely decorative, intended to denote "smart thinking." Until today it has been used without limitation in any activity, almost as a surname, among which we find: strategic public relations, strategic social communication, strategic protocol, strategic marketing, strategic psychotherapy, strategic medicine, etc. In fact, I have found some that are even more aberrant than those indicated: strategic operations, strategic tactics, strategic therapy, strategic psychology, 
strategic massage, strategic engineering, strategic mathematics, strategic physiology, strategic philosophy, and a very peculiar one - strategic metaphysics.

The "professionals" working in these areas do not have any idea what "strategic" means. On the other hand, concept migration to other disciplines is acceptable, as long as the core significance of the concept is maintained. However, this research discovered, in the process of studying the problem, that with their drafts of the definition and roles of strategic communication, disciplines such as public relations, marketing, advertising, journalism, and many others have failed in their attempt to migrate the concept. They have also (while attempting to fulfill their roles working in the security and national defense area, confused management with planning, strategy with operation, and operation with tactics, along with many other atrocities.

\section{About Strategic Communication for Security and National Defense}

Up to this point, strategic communication in the area of security and national defense has been neither an instrument nor a method, a doctrine, nor a policy. It does not possess lineaments, missions, or roles, and does not pursue any clear objectives. It only has attempts at definitions, without any official study to substantiate them. This research has concluded that today, strategic communication in the area of security and national defense is nothing more than "a project idea" - a draft of definition without any theoretical or methodological basis, and a logical practice mired in a battlefield of disciplines and professions that intend to adopt the concept in one way or another without any attention to the intellectual consequences. They forget the significance of the strategy concept and unsuccessfully try to accommodate it, regardless of the mutilation of the lexicon.

\section{About Strategic Communication in Other Areas}

With full confidence in this research, and based on the obtained results I can say that strategic communication is not marketing, advertising, public relations, journalism, psychology, sociology, social communication, visual communication, anthropology nor any other area related to these. However, strategic communication should fulfill the role of selecting, leading, integrating, coordinating, activating, and executing the resources of these disciplines in order to support the national objectives and permanent interests of a nation-state.

Until now, many organizations have had their own definition of strategic communication, which is almost always a malformation of the strategy concept associated with any activity that plans a communication campaign (this is publicity in the case of private enterprises, and social communication in the case of public enterprises). It is noteworthy that journalists who are working in security and defense sector call informing the community about what the institution does "strategic communication," although it is actually more connected with public relations and social assistance. These are far removed from the strategic dimension and action fields of a nation-state, and so do not develop strategic communication, but rather only communicate socially. 


\section{About the Lineaments of Strategic Communication for Security and National Defense}

This research discovered in the qualitative-quantitative process that strategic communication must integrate the qualitative analysis instruments of mass communication and prospective decision-making and quantitative-probabilistic analysis tools of strategy. All of these must be structured with the "integral action logics," communication platforms, and "action courses" of the relevant actors of the scenario; the origin of the conflict; the odds, measures, and percentages; the courses of action; and the intervening factors in every stage of the scenario, as well as the behavior of the actors in the past, present, and future.

Therefore, strategic communication for security and national defense must have the lineaments of strategy:

- Pursuing the national interests and the political-strategic objectives of the nation-state

- Working in the political-strategic dimension.

\section{About the Missions of Strategic Communication for Security and National Defense}

Based on the qualitative analysis, the missions of strategic communication for security and national defense should support the national security strategy and national defense strategy by contributing to maintaining, protecting, and achieving the national interests and objectives of the nation-state, which are divided across different temporal periods (peace, crisis, war).

- In times of peace: to achieve deterrence in the hemisphere and strategic stature in the international system

- In a state of crisis: to obtain credibility in the international system

- In a state of war: to achieve internal and external legitimacy in the international system in order to obtain freedom of action.

In conclusion, through this research it has been possible to elucidate the definitions of what strategic communication for security and national defense is, what its missions and objectives are, and how it should act. It also provides a proposed model for strategic communication for security and national defense that was generated with the knowledge gained.

As a researcher, professional, and academic working in this field, I am very pleased with what has been explored and designed, since the exploratory study found that strategic communication for security and national defense aims, as part of its mission in supporting the national strategy, to achieve deterrence (dissuasion), legitimacy, and freedom of action in the international system. It is my personal objective to continue this research and proceed to a new stage in order to create a methodology and work system with a research proposal for a pertinent entity, university, or center of studies.

As the National Defense Authorization Act for Fiscal Year 2012 states: 
The committee also encourages the Department of Defense to continue to pursue workforce development opportunities that bring together diverse skill sets and career specialties. For example, the Department should do more to integrate social science skills, cultural intelligence, and human terrain understanding to the IO and SC field. The committee also believes that as the Joint Chiefs of Staff evaluate joint SC and IO training and education curricula, it ensures that it maintains and sustains existing centers of excellence. $^{21}$

Strategic communication is undoubtedly a vital tool for a nation-state, one that supports the national strategy, aims to achieve and protect the political-strategic objectives and national interests, and above all maintains the peace. Finally, without strategy, we can only communicate. Only with strategy we can communicate strategically.

21 U.S. House of Representatives, "Report of the House Armed Services Committee on the National Defense Authorization Act for Fiscal Year 2012" (Washington, D.C., 12 December 2011); available at http://www.gpo.gov/fdsys/pkg/CRPT-112hrpt329/pdf/CRPT-112hrpt329pt1.pdf. 



\title{
The Asymmetric Warfare Environment as Described by the Participants
}

\author{
Giuseppe Caforio *
}

\section{Introduction}

The completion of a cross-national research study on a sizeable sample of military personnel who had participated in asymmetric warfare operations has resulted in a variety and breadth of survey material that is deserving of further examination. ${ }^{1}$ Additional study of the data gathered in this research is particularly important in order to recon-

Giuseppe Caforio is retired general of the Italian Army. He is past president of the Research Committee 01 "Armed Forces and Conflict Resolution" of the International Sociological Association (for 12 years), vice-president of the Italian Interuniversity Centre of Historical and Military Studies, founding member and coordinator of a working group of the ERGOMAS, as well as member of several other institutes of research. He is too an outside consultant of the governmental Italian Centre of Strategic and Military Studies. He has a Strategic Sciences degree, a Law degree, a Political Science degree, a Master in Communication Science. He has authored or co-edited over 160 scientific publications (books, articles in journals, chapters in joint monographs, etc.) on various sociological, political science and methodology issues at an international level in Bulgarian, Chinese, Dutch, English, French, German, Italians, Russian, Slovenian and Spanish. The research study described in this article was conducted jointly by the Research Committee 01 of the International Sociological Association and by the Working Group on the Military Profession of the European Research Group on Military and Society (ERGOMAS). The report drawn from the research is in the course of publication with the title "Soldiers without Frontiers: The Experiences from the Ground."

1 "Asymmetric warfare" describes a conflict that pits a weaker side against a stronger adversary, and from the use of war-fighting techniques that are vastly different from the traditional ones that enable the weaker side to stand up to its stronger adversary. For more research on this subject see, among others, Matt Armstrong, The Art of Asymmetric Warfare, a blog on public diplomacy and strategic communication in the twenty-first century (28 July 2008); Roger W. Barnett, Asymmetrical Warfare: Today's Challenge to U.S. Military Power (Washington, D.C.: Brassey's, 2003); Giuseppe Caforio, "The Asymmetric Warfare: In Search of a Symmetry," in Armed Forces and Conflict Resolution: Sociological Perspectives, ed. Giuseppe Caforio, Bandara Puarkayastha, and Gerhard Kümmel (Bingley, U.K.: Emerald Group, 2008), 7-23; Caforio, "Officer and Commander in Asymmetric Warfare Operations," Journal of Defense Resources Management (April 2013); Th.A. Van Baarda and D.E.M. Verweij, The Moral Dimension of Asymmetrical Warfare: Counter-Terrorism, Democratic Values and Military Ethics (Leiden: Martinus Nijhoff Publisher, 2009); and Alise Weibull and Bengt Abrahamsson, eds., The Heritage and the Present: From Invasion Defence to Mission Oriented Organisation (Karlstad: Swedish National Defence College, 2008). 
struct the environment of this type of warfare, with special regard to the human impact of such conflicts on the participants. ${ }^{2}$

This closer look is possible because of the way in which the research was conducted, by means of in-depth, semi-structured interviews, which gave the interviewees a chance to go beyond the topics strictly pertaining to the interview's structure and to talk more expansively about their lived experiences, emotions, and backgrounds. The richness of this data will be rendered in this essay through direct quotation of the interviewees' responses, preserving their vivacity and, at times, simplicity, and limiting the comments of the article's author to a minimum.

The essay deals with four aspects of asymmetric conflict: its nature as seen by the participating soldiers, their relations with the other actors present in the theatre of operations, their assessment of how the soldiers to be sent on a given mission were selected and prepared, and the particular experiences gained in the theatre.

\section{The Nature of Asymmetric Conflict}

The first topic that is examined here is the nature itself of asymmetric conflict, as it appears in the testimonies of the protagonists, in its dual aspect of war-fighting on the one hand and civil action on the other. In many instances, this latter aspect of the work took on the de facto nature of civil replacement; soldiers were asked to carry out tasks and functions that in that particular territory at that particular moment were not being performed by the civilian authorities who were normally responsible for them. It is well known and amply discussed in the literature on this subject (see footnote 1) that one of the chief (and contradictory) characteristics of asymmetric warfare is precisely the mingling of these two aspects and their constant intersection. This characteristic also poses one of the greatest difficulties to the service personnel involved - that is, the necessity of being able to pass at any moment from the role of the social worker to that of the combatant, and back again.

We have gathered abundant data on both of these aspects. Indeed, if we consider, by way of example, the current conflict (now in its eleventh year) in Afghanistan, I believe that there can be no doubt with regard to its characterization as a war. This statement is borne out by the number of dead and wounded, the use of war munitions (quantitatively and qualitatively), the type of means deployed, and the combat situations that have occurred. And, as a war, it is a particularly insidious one, due to the mingling of the insurgents with the civilian population and their use of guerrilla techniques and terrorism. These qualities of the Afghanistan conflict are amply recorded in the experiences of the soldiers participating in the ISAF coalition. And the same applies to combat experiences in other theatres that have received less media coverage but that have been equally characterized by episodes of asymmetric warfare, such as Africa, the Middle East, the Balkans, etc.

2 The theatres in which the interviewed soldiers chiefly had their experiences were: Central Africa, Afghanistan, the Balkans, Iraq, Lebanon, the Persian Gulf, and the Philippines. 
Participants experienced the asymmetric conflict environment as a true war theatre and this fact is reported by numerous testimonies, such as:

I was involved in a big fire fight on June 11, 2009 and appreciated how my mates reacted to the fire. I was in command of an armored craft ("Lince"): my machine gunner was wounded on his arm, but he remained at his post. The craft behind me was heavily hit (two casualties) and a pickup truck carrying Afghan soldiers was blown up by an IED: I talked with them few minutes before, and was hit particularly hard by their death (Italian NCO, deployed in Afghanistan).

In Sudan, I experienced more attacks of guerrilla groups towards the peacekeepers. These groups are the ones who are supporting the government, and they were specializing in attacking tribes, peacekeepers, car-jacking and kidnapping (South African soldier).

When I was assigned in Mindanao, the combat operations were brutal. In Cotabato, in one instance, my fellow soldier was killed after he went to fetch water (Filipino sergeant).

I've been under fire in Somalia ... But otherwise it's probably Afghanistan that has made the greatest impression on me in connection with IEDs (Danish soldier).

We have fired warning shots, both with the cannon on the ship, during a hijacking of a big ship, and our helicopter also fired warning shots with a TMG [heavy machine gun]. The same applies for the FRØ'ere (special forces) with which we sailed, they also fired warning shots. We have also blown their ships up (where I participated) (Danish sailor).

I took part in fire fights as a Mangusta [helicopter] pilot. Our job was to provide force protection to army units. Once a big truck column, escorted by Afghan and Spanish units, fell into an ambush in a very narrow valley and was hit by intensive fire; they asked for our support, and we intervened with two Mangusta and searched for and engaged insurgents, firing rockets and shooting at them with a small-caliber gun for an hour and a half" (Italian pilot, in Afghanistan).

Given the frequency and intensity of these encounters, the sense of relief felt by participants when armed clashes did not take place is consequently high, as related by a Slovenian soldier: "No combat operations, but we were prepared if something would happen. Sometimes it's kind of the dream that doesn't come true - you are being trained for a hard job, but at the end of the day you don't get what you wanted. On the other hand, when you think that you may die, it's good that we weren't engaged in a difficult situation, and that we all survived...."

This raises the fact that asymmetrical warfare is a very particular type of warfare, because it takes place in the midst of civilian populations from whom the insurgents are frequently indistinguishable. In such settings, every activity carried out by military units affects the lives and attitudes of these populations, a fact that is testified to by reports like the following one, relating to an action carried out by a Canadian unit: ${ }^{3}$

3 See Sean M. Maloney, "Incursion at Howz-e Madad: An Afghanistan Vignette," Canadian Military History 17:1 (2008): 13. 


\section{THE QUARTERLY JOURNAL}

When Canadian forces built a combat road (Route SUMMIT) from Bazaar-e Panjwayi to Highway 1, there were unintended consequences. The construction of this road diverted water in the east end of Zharey. Age-old and intricate tribal agreements over water use were now disrupted. Certain communities now had the potential upper hand over others, and resentments built up bordering on violence. A Canadian solution was to put in culverts to restore the water use patterns - but the culverts made ideal locations for IED (improvised explosive device) attacks against forces using Route SUMMIT. When culverts were blown up, was this Taliban activity or not? If one community resorted to AK-47 use over a diverted stream, was this Taliban action? What if Canadian troops were caught in the crossfire? Or, what if Afghan police from one area were conducting activities on behalf of someone else for pay because they had not received monies from their own chain of command for months? These factors complicated any Canadian response to activity in Zharey District.

Many of our interviewees provided similar testimony that attested to the difficulty of being involved in confusing conflict situations in very close quarters: "In one engagement, I hesitated for a moment because the rebel was a female. I shot her anyhow at ten meters range" (Filipino soldier, Philippines). Or, as a South African solider deployed in Sudan described his experience: "It was a bit scary, but shocking at the same time, because I saw almost everyone on the streets were armed, so I could not see the difference between armed forces and civilians."

A fundamental characteristic of asymmetric conflict (and the origin of its complexity) is the mixing of combat operations with a series of activities that are aimed at improving the living conditions, mobility, and education of the local population. This characteristic, summarized in the imperative "to win the hearts and minds" of the local population, was abundantly illustrated in the interviews that we conducted. ${ }^{4}$

We are peacemakers. We did school construction, medical and dental missions, circumcision, joined in their events/parties, worked on the construction of roads and public information campaigns (Filipino official, Philippines).

Well, I had direct contact because I taught. Alongside Base España there was a school. It is a small school attended by children from the nearby town, from seven to twelve years old. I have been teaching them. I had an interpreter, and I taught gymnastics (Spanish NCO, Lebanon).

Our main activities are non-combat in nature, mostly civil-military operations (Filipino soldier, Philippines).

We may have to perform missions of a very different nature, more humanitarian and quite logical and reasonable (Spanish soldier, Afghanistan).

I worked as head of a cell working on civil-military cooperation [CIMIC]. Civil-military cooperation is very important, because it is a tool in the hands of the commander to make the environment friendly and to complete the mission in an easier way (Italian officer, Afghanistan).

4 See David H. Petraeus, "Learning Counterinsurgency: Observations from Soldiering in Iraq," Military Review (January/February 2006): 2-12. 
I gained experiences in working in a very different environment than at home, and experience with mentoring (Slovenian NCO, Afghanistan).

The two functions that troops are asked to carry out in asymmetric conflicts-military and civilian - are often intertwined: "Together with the local police we carried out territory control, convoy escort, but particularly territory control. Besides, I distributed humanitarian aid," an Italian soldier reported. His Spanish counterpart stated: "We had to perform missions of a different nature, more humanitarian, but in Afghanistan you come to see how suitable our training is. Fortunately or unfortunately, we have to use on the ground what we have learned in our training." And a Spanish officer said of a commander: "He stresses that the concept of civil-military cooperation is becoming a core concept in Afghanistan."

In summary, with regard to what is asked of the individual soldier in an asymmetric warfare environment, one must conclude with Mario Renna that "the modern soldier must know how to fight, but also how to prevent and persuade, understand about explosives but also about building schools, he has to know how to speak in public and to address listeners who are sometimes hostile or mistrustful...."5

\section{The Different Actors Present in the Theatre}

The soldiers deployed on asymmetric warfare missions found themselves interacting with numerous other actors in the theatre. The most significant interactions that left the strongest mark in the memories of the interviewees were those with the personnel of other armies that participated in the mission (consider that in Afghanistan, for example, the coalition was made up of forces from forty-two different countries), those with the local population, and those with the insurgents.

\section{Relations Between Soldiers}

The relationships and comparisons with the soldiers of other armies appear to be particularly significant in the recordings of the interviews, above all for the aspect of comparison between one's own organization/institution and that of one's partners. Added to this is the aspect of national and cultural differences, which are cast into high relief through the daily interactions on joint deployments.

With respect to the first aspect, the primary comparison is generally made to U.S. troops, who were deemed by most of the interviewees to be the most professionally advanced and therefore most worth measuring up to. A Bulgarian soldier relates, for example: "Because I used to work with colleagues from the U.S. Army, my experience is mainly with them. Originally they seemed haughty and dismissive, but once they were convinced of the quality of the Bulgarian military, they totally changed their mind." Concerns with being up to standard and being perceived as such stand out here.

5 Mario Renna, Ring Road, sei mesi con gli Alpini in Afghanistan (Milan: Mursia Editore, 2011), 83 . 
Paying closer attention to the U.S. forces also led some soldiers to note what they considered to be defects in U.S. performance and attitude, in particular forms of arrogance in relation to the other military contingents:

Power differentials are one of the major differences among different cultures, but it was not difficult to adapt. Most of the military personnel were U.S. in NTM-A HQ. So, U.S. folks were conducting daily life as if it was a pure U.S. HQ. They were doing some ceremonies according to U.S. traditions, since they were the majority. I respected their rituals. But in a multinational environment, there must be a multinational culture and daily life. I don't have to celebrate U.S. holidays, and I don't have to eat meals on a dining table covered by a U.S. flag (Turkish officer, Afghanistan).

Since we are in a foreign country with the aim of bringing them peace, those local people and local army personnel deserve respect from our cultural point of view. But this is completely different for some other countries, especially Americans. British soldiers pay more attention to this, but American soldiers do not consider what the opposing person might feel. For example, an American NCO may chew an Afghan general out for not bringing enough ammunition for a live fire training (I witnessed this event). I went to the general and asked why he let him behave like that. The answer was sad, because he said that he received his salary from that NCO. The British at least refer to those local officers that are of higher rank as "sir." When I asked a British NCO about this difference, he said, "Americans still have a long way to go. We had some experience in the past. We also have a long way to go, but we are ahead of the Americans" (Turkish officer, Afghanistan).

In other cases, it is the concrete comparison, especially on the level of logistical organization, that takes center stage: "I felt that logistical support for soldiers in the U.S. military was enormous (e.g., support facilities such as gyms, swimming pools, PX, mess halls, etc., and programs for leisure time through voluntary participation). On the contrary, I felt that support in our case is insufficient, and leisure time programs sometimes appeared as a burden, like an obligation or daily routine (Korean soldier, Afghanistan).

It is a comparison that also extends to other coalition armies, however, according to individual experiences, as a Bulgarian NCO observed:

In Afghanistan, I was at the base of the British Army, in which the only thing you had to think of was how to perform your duties. For everything else was taken care of:

1. Laundry: British washing machines - you went, left your clothes, and the next morning they are washed and prepared, with perfume sprayed on.

2. Food: The base has four canteens. You have the right to eat where you like. The food was varied, at least five types of different food in each dining room.

3. Free U.S. Internet: You can talk thirty minutes a day - enough for everyone.

4. Three sports halls: Only if you have time and desire for sports.

5. Five different shops: Whatever you needed, it was there.

6. Five pubs: If you like to drink coffee, cola, it was all there.

We also received specific remarks in relation to the contingents of other countries: 
During KFOR 22 we were in the French camp. It was strange. They were arrogant, and unable to speak a foreign language. They disliked speaking English. In the canteen, we sat at each our tables: Moroccans, Slovenes, Germans, Swedes, etc. (Danish soldier, Balkans).

We (the Danes) had just moved, so I missed the kitchen. We've gone from 300-400 to 200 men in the French camp. But it worked well enough. There was the problem that the French did not speak English - until after ten beers. Confidence was OK. ... There were also the Moroccans who had the guard service. They were weird. Many of them had been there for three years. They returned home just before the rotation, and could then have time to assemble the next batch. They were weird; they did not speak English, but French (Danish soldier, Balkans).

U.S. soldiers are kind, and they generally praise their colleagues and subordinates and try to solve problems for their team members. The Italian soldiers, they are fun but do very little. Female soldiers think, Italian guys are attractive and try to get together with these guys.

I and other non-native foreign officers had some difficulties understanding New Zealand and Australian officers. My best friends are from the countries that are near to the Mediterranean Sea-Italy, Spain, Portugal, Greece, etc. We were very close with Greek officers especially.

French officers always tried to say some words at the start of every meeting. I think that they intended to show that they had important opinions on every subject and that they affected coalition decisions (Turkish officer, Afghanistan).

But there are also those who expressed negative judgments on their relations with the soldiers of the other countries with whom they came into contact, such as this South African NCO (in DRC): "With respect to soldiers from other countries, jealousy exists. They hate the RSA with a passion. Especially the Indians and Bangladeshis. They send RSA troops to the red zone and then to green zones. When an RSA soldier is reported for a minor case, they are quick to judge and report us to the UN. Whereas I know of a situation in which Guatemalan troops were caught red-handed sleeping with local women, and nothing was done to them. They just hate the presence of RSA troops in the DRC."

\section{Relations with Local Populations}

The contact of soldiers from developed countries with the local populations of less culturally and economically developed countries (which are those where asymmetrictype conflicts have tended to arise) generally leads to feelings of compassion regarding the poor living conditions of these populations and of dismay at the local situation.

I never thought and expected people to live in such terrible living conditions as they are living in Afghanistan (Slovenian soldier).

I was shocked by the damage and the harsh conditions of the country. You get to see many problems, a suffering society and the hatred they feel one another. It is very different from our comfort in the Western countries. You arrive to a very different place. You notice you have to help them improving their living conditions (Spanish NCO, Afghanistan). 


\section{THE QUARTERLY JOURNAL}

When arriving in Afghanistan for the first time I thought I arrived at the end of the world. Everything was very dirty. Afghanistan is one big garbage dump (Slovenian soldier).

I find out that there are people who are suffering, somebody can kill your family member, and no case will be opened, because he is in power with his group. They can take anything, no matter what you have, without any permission. Thank God we are South Africans. Hunger is their daily meal (South African soldier deployed in Sudan).

The experience of racial conflict is striking: "In terms of the local population, it was interesting that the Tutsi got on very well with the white officers - they are the minority. The Hutus were less friendly. All the interpreters were Tutsi, and this was problematic as they hate the Hutus. 'They can teach South African's something about racial hatred' - was the comment" (South African officer, Rwanda).

There was also a commonly expressed sentiment that the local population took an exploitative attitude toward the peacekeepers:

The local population definitely saw the opportunity to exploit the RSA soldiers to the maximum. We utilized their local knowledge and rewarded them accordingly. But nothing you got was for free. Social, sport, etc. interactions always had a price you had to pay. Unfortunately our soldiers exploited their poverty status by exploiting their ladies (South African officer, DRC).

People accept all soldiers as invaders regardless of their national classification. They just want to get some benefit like money or food from you. This is the way most of people behave toward us (Turkish officer, Afghanistan).

Among the soldiers on a mission, an attempt at comprehension toward the local populations was prevalent. Many soldiers discussed efforts to understand local customs, language, and culture: "The relation between us and the DRC people - for me it was good, because I always wanted to know how are they living and I even taught myself the language so that I could understand them better. I'm just not happy with the way they live. They work like slaves, especially females and children, and it seems like men are the most relaxed people there. Most people don't have jobs, some don't even have places to stay" (South African officer, DRC). This attempt at understanding was facilitated in some cases by cultural and/or religious affinity: "Local people had the same culture like Turkish people, so that Afghan people and Turkish officers were able to understand each other easily. Also, religion was an important factor in establishing a good relationship with local people" (Turkish officer, Afghanistan).

There is no lack of curious episodes in the relations between very different cultures, like the one reported by a Bulgarian officer: "There was a rumor spread among the locals that when we use sun glasses, we can see them naked. Many of them believed it. When I realized this, I gave my glasses to the interpreter to see me 'naked,' and that was how I broke this myth."

\section{Relations with Insurgents}

Relations with the insurgents are lived for the most part as relations with phantasms, with an invisible enemy. In most cases the interviewees had not actually seen the insur- 
gents. An IED, whether identified or exploded; a hit-and-run attack on a column of vehicles; a hail of mortar and rocket fire; the fear of reprisals and the hostility of village chiefs - these are the manifestations of the insurgents with which most of the soldiers we interviewed came into contact. If we examine the individual interviews, we can glean experiences of this type of spectral relationship:

There were bullets coming 'from nowhere' (Bulgarian soldier, Afghanistan).

Attacks often come from the villages, and you don't know where and against whom to fire, because we were very careful not to hit civilians (Italian officer, Afghanistan).

In some instances I have experienced pursuing enemies that seem to just disappear. This is an indication that they indeed have local protectors (Filipino NCO, Philippines).

Definitely there were women and children combatants (Filipino NCO).

Yes, it is difficult because they only shoot without observing who are they shooting, and some are not in uniform (South African soldier, Sudan).

However, there are exceptions that are worth citing:

The so called 'guerrillas' or 'soldiers' are mostly economically motivated criminal gangs. They do not fight ideological wars, although the gang leaders become politicians to further their economic aims. In essence they are just criminals (South African soldier, DRC).

I have to tell you my personal story. In one engagement, I hesitated for a moment because the rebel was a female. I shot her anyhow at ten meters range. It turned out that she was a former student at UP Cebu; she was called 'doctor' by the communist group because she was a medic (Filipino officer, Philippines).

The rebels were dressed exactly like the Sudan forces and they ordered us to stop (South African soldier, Sudan).

A Spanish officer even evaluated the insurgents' combat abilities. He contrasts "the will to die for their cause of the Taliban with the reluctance of the Afghan Army to take control of the military operations and stability efforts."

A separate discussion must address the experiences of sailors, who, in the fight against piracy, have in many cases had direct experience with the pirates they are working to stop. An Italian sailor, for example, reported: "In these occasions we had human contact with people from very different origins and typologies. Few pirates are really from Somaliland: most of them come from Yemen, Pakistan, India too. The Somalis normally stay on the 'mother boat,' a fishing boat from which small and speedy motorboats depart to board merchant ships." Another sailor commented, "I was impressed by the pirates' mood: they have a way of thinking very different from us. To be a pirate is like another job, according to them." A third sailor described the pirates' fighting methods: "The pirates usually had mother ships, which were fishing boats, with which they captured small craft of fisherman or others (especially Yemenites), sometimes killing them, sometimes setting them adrift on a small boat. The fishing boats were also procured in this manner." 


\section{THE QUARTERLY JOURNAL}

This is not solely an Italian experience. A Danish sailor reported, for example: "We have not been under fire, but one day we had to stop a pirate boat. The helicopter was in the air, and we had to stop the boat, but they would not stop, so we fired warning shots, but they did not stop until the sniper fired a warning shot into the top of the hull. Then it really occurred to me what it was we were dealing with. They were totally unaffected that we had fired on them, and that gives you a good impression of what kind of people they are." A South Korean midshipman also encountered pirates at first hand: "I had an opportunity to observe closely a suspected pirate vessel, to recognize the behavior of pirates towards combat vessels, and to gain know-how of the confrontation operations of suspected pirate vessels."

In short, the experience of the insurgents appears to be well illustrated by what Mario Renna writes (in relation to Afghanistan): "To describe the members of these groups [of insurgents] newspapers and television often simplify, speaking generically about "Taliban"; a strong image that evokes not only a military but also an ideological adversary. The reality is much more fragmented, however: in fact, national security forces and NATO patrols are attacked by criminal bands, opium smugglers and hired, more or less anti-Western irregular militias." 6

\section{Selection and Training of Personnel}

The concrete experience of operations in asymmetric warfare environments puts the training that soldiers have received beforehand under severe scrutiny, as well as the process of selecting the personnel to go on these missions. The interviewees from all of the countries represented in our study appear to be particularly critical with regard to personnel selection. For example, among the Bulgarian officers interviewed, affirmations of the following type were recorded:

The selection of officers should be extremely thorough and designed to meet international requirements.

I suggest ... to select people very carefully; it is unacceptable to send officers to occupy positions for which they have not been trained - for example, sending a staff officer to a position in the intelligence cell of the division.

We should work to end the selection of people to participate in a mission on the basis of 'connections' (informal and friendly relations), and to improve the selection of people based on open and transparent criteria.

With regard to training, general military training for conventional combat was typically considered to be sufficient; however, the various challenges of asymmetric warfare were held to require more specific forms of preparation. A South African officer stated, for example: "I think more training in the asymmetric field would have assisted me in handling the situation. Conventional war is simple and straightforward. My training was definitely inadequate for the task I was given, and that goes for everyone

6 Mario Renna, Ring Road, sei mesi con gli Alpini in Afghanistan (Milan: Mursia Editore, 2011), 13. 
who was under my command. More emphasis during training should be placed on irregular or asymmetric warfare. Our unit should focus on asymmetrical warfare training and put members on similar smaller operations or simulations to gain experience and exposure during training. There must be panic inducing situations."

Preparation for commanders that centered on supplementation and sharing the experiences that their predecessors had on the ground was also felt to be important, in addition to more practice in the English language, as a Bulgarian officer pointed out: "There must be interactions between people who have occupied a position in a past mission and people who are about to hold that position. There must be more detailed information about the environment in which someone is going to work (for both military camps and the area of operation). Language skills have to meet the modern NATO standard. Additional language training, including professional terms, acronyms, conversational skills, etc., should be developed. Local pilots were required to fly under the rules of ICAO and NATO, which are written entirely in English, but it was very difficult for them, and there were many misunderstandings, especially when they were talking to Americans and Englishmen."

Sharing the experiences of those who preceded them in the theatre is something that many of the interviewees called for. As one Korean soldier said, "In order to enhance the level of pre-deployment training, we may have to transfer certain types of knowledge from experienced personnel, and the unit in charge of deployment has to prepare for deployment more systematically. One of his comrades noted: "Since we were deployed as the first contingent to Afghanistan, plenty of time was needed for preparation. During the period of preparation, the U.S. and Australian military personnel who had experience there came and gave us a great deal of help."

This transfer of previous knowledge was especially valuable because, as a Slovenian soldier said: "Everything is different, different climate, way of work. You cannot train enough at home if we don't have weather that reaches 50 degrees." Preparation aimed at replicating the peculiar characteristics of asymmetric warfare was felt to be particularly essential, because, as a South African officer stated: "We were trained in terms of what to do when under fire, not how to negotiate, how to deal with accidents, how to handle opposing forces when weapons were drawn but not fired." Another South African officer added: "Yes, there is a need for better training in people skills, negotiation skills and cultural awareness. We definitely need more social workers on these operations." Because the characteristics of good training for the asymmetric environment are peculiar, as another soldier pointed out, "They also educated us on how to calm somebody to get their trust and to win the mind and heart of the local population."

Basically, for the great majority of the interviewees, training for conventional combat is necessary, and was well provided to the soldiers making up the sample, but it must be supplemented with specific training in other aspects of asymmetric warfare, training that in various cases is deemed deficient. The soldier to send on asymmetric warfare missions, in order to be well prepared as a soldier, must definitively also acquire preparation as a social worker, negotiator, arbiter, and expert in civil-military cooperation. 


\section{The Experiences Gained}

Whatever assessment one wishes to give of participation in asymmetric warfare missions, it involves a series of experiences that leave their mark on the soldier's entire life, both professional and non-professional. This is clearly asserted by all of the interviewees who, nearly unanimously, consider having participated in such missions a positive experience. For our purposes here, rather than make a detailed examination (such as in percentage terms) of the enrichment that having participated in operations of this type brought to individuals, it seems more interesting and in the spirit of this article to report in the interviewees' own words a series of personal lived experiences, both negative and positive, each with its particularities.

The former are obviously more numerous than the latter, as these people experienced a war environment where frustrations can be frequent, as appears in the following testimonies:

There was also a night we were going down to look at a merchant ship that maybe had been hijacked. It turned out that it was hijacked, and when they saw us as daylight came, they began to threaten the crew on board and called us up on the radio and threatened to harm the crew, so we sailed away again. You feel a tremendous frustration at not being able to help these poor people who have been hijacked (Danish sailor, Persian Gulf).

I saw while we were driving a rebel group open fire at three young women, killing two and injuring the other; you feel helpless, because I only had one armed escort, and we could not risk being two and having to go against a gang (South African soldier, Sudan).

Much more particular is the macabre experience reported by a Danish major during his activity in the Balkans:

Exchanges of corpses (from my diary). I'll have to tell you about corpses and what these can be used for here during the war and how they can be kept. Corpses are a commodity! Better than money, which means that the individual manager within his area of responsibility buries the corpses of the enemy at approximately $60 \mathrm{~cm}$ depth. This, after he has wrapped the bodies in plastic or whatever is at hand. It can, as I saw in several cases, be plastic from packages of oranges. If a single chief loses terrain, he is forced to dig up the corpses and move them to another area because dead bodies, as I said, are a commodity. The bodies can be used as a means of payment (exchange) for corpses of one's own men, or as payment for food. Depending on what it is you want to get in exchange, it must be made through negotiations. This was my biggest task in Bihac, to attend these meetings, ensuring that security was in order and to ensure that the agreements were respected to the letter, which means that I often helped to dig up the bodies and then load these on to our own trucks, and not least to make sure that it was the right number of corpses. I will not dwell on all these exchanges, however I will mention a few in particular which made an impression on me.

On 28 May 1995, the Bosnian foreign minister, Irfan Ljubijankic, was shot down by rebel Serbs near Bihac. He was shot down along with three other cabinet members of the Bosnian Serbs when his helicopter was on its way to a meeting.

After some initial meetings in Licko Petrovo Selo, it was finally decided that on June 7 an exchange of corpses would take place between Serbs and Muslims regarding the four persons who had been shot down on 28 May. I've never participated in some- 
thing similar. The Muslims came with thirty-nine corpses and three POWs. We usually carry around eight corpses on our trucks; the Muslims had no military truck, so they had piled the thirty-nine corpses on a small truck, which meant they had to crawl on top of dead bodies to get them out. Some of the corpses were no longer able to hang together. When the bodies were finally unloaded, a process was started to piece together some of the corpses. Some corpses were missing a leg, an arm, a hand, a foot. And, not to repeat myself, the corpses were not transported in any kind of coffins, but in plastic of any kind - it was a particularly macabre job. Naturally problems arose when the other party felt or found that there were missing parts of the corpses. Besides those of us who were usually attending these exchanges, there was at this exchange almost half the world's press, who naturally were all photographing. All in all, an ugly experience.

Another painful experience, again in Bosnia, recalled the atrocity of the extermination camps of World War II, here with regard to the exchange of prisoners:

A few days later the Serbs handed over eighteen prisoners of war who had been in a POW camp for eight to twelve months. The actual transfer took place without any problems, but it must have been an incredible experience for those who were transferred, and it must have felt like winning the lottery. We've all seen films of concentration camps from the Second World War and how people were treated, the emptiness of their eyes visible to everyone. That was it for me when these POWs came limping, stumbling, on crutches over to a life they thought they would never experience again. Never have I seen greater emptiness than in those eyes of those people who until they stood with their arms around their loved ones did not think that they would experience this again.

The interviewees often witnessed disturbing moments, like that one reported by a Spanish sailor in the waters off Sarajevo: "When I got really shocked was during Christmas of 1994. I was a rookie, and I remember being on the aircraft deck, which now is prohibited, and asking a companion about the lights I saw from the boat. I thought they were celebrating the feasts, but it was Sarajevo being bombarded."

But the interviewees' experiences were not uniformly negative. The positive experiences that were reported were those in which the soldier, whose mission is always one of peace, can see that the action undertaken and completed has managed to change the local situation. We will offer few examples in this vein:

It was nice to see the kids go to schools established by the ISAF, see them play ball outside schools. Seeing the population (some) get better, women in women's centers, etc. (Danish soldier, Afghanistan).

A good experience was - at the end of the mission - to go to a village and find an open air market, people wearing party clothes, walking and trading: a normal situation, very different in respect to the first time I went to the same village, when it seemed like a ghost town (Italian soldier, Afghanistan).

Once the local population warned us that some rockets had been placed to be used against us; they indicated the site, and we proceeded in destroying them. Another time we organized a shura, which 250 heads of villages took part in. We had the opportunity to explain our work, our intentions, etc. The result was very positive, and allowed us to better understand the Afghan reality (Italian officer, Afghanistan). 


\section{THE QUARTERLY JOURNAL}

Operation Green Angel, a civil-military operation, was planned to spend two to three weeks repairing villages that had poor living conditions, and once the work was done, we got together to play with the village people. We really enjoyed getting acquainted with them. Through working together for two to three weeks, we became closer by talking about life here and there (Korean soldier, Afghanistan).

The satisfactions achieved in terms of personal and professional enrichment appear to be both important and widespread:

I personally gained a lifetime's experience which I will never forget. It was fun, scary, and sad. Your bond with your fellow mates got stronger and protective over each other; you form a family (South African soldier, DRC).

I am very satisfied. I work a lot more professionally now. I have learned to say No and to ask for help when it became too stressful. I've developed a great deal, both personally and professionally. I have matured and grown, and have gained a different outlook on my life after seeing people's conditions in Africa; I am not just taking things for granted anymore. You see how well off you really are. I've also learned to work with my colleagues in a completely different way after we've been through these episodes where something happens with pirates. You learn to communicate in a different way during stressful situations, etc. (Danish officer, Persian Gulf).

\section{Conclusion}

As I have already had occasion to note in another essay, ${ }^{7}$ for militaries at all levels, operating in an asymmetric warfare environment means being prepared to act "in the presence of civilians, against civilians, in defense of civilians where civilians are the targets, objectives to be won, as much as an opposing force." 8 It means forgetting some fundamental principles of combat, and accepting the use of minimal force, and even that only when strictly necessary. It means that leaders need to acquire the ability to motivate themselves and their men, and to apply these limitations, in the process accepting greater personal risk. It means being able to assume governance roles in local settings that have very different cultures, norms, and customs from those of one's home country. It means being prepared to manage a multiplicity of functions simultaneously, not all of them military. It means acquiring interoperability with military contingents of nations that are very different from one's own. It means having to expand one's professional toolkit into sectors and disciplines that are far removed from one's education

7 Giuseppe Caforio, "Officer and Commander in Asymmetric Warfare Operations," Journal of Defense Resources Management 1 (2013): 9-26.

8 Bengt Abrahamsson, "Restraint, Unbridled Emotion and War Amongst the People," in The Heritage and the Present: From Invasion Defence to Mission Oriented Organisation, ed. Alise Weibull and Bengt Abrahamsson (Karlstad: Swedish National Defence College, 2008), 147-68. 
and training. ${ }^{9}$ It means all this and even more which, from time to time and from mission to mission, proves to be important and necessary.

The essay presented here has dealt with four aspects of asymmetric conflict from the point of view of the participating military personnel: its nature, the relations between the different actors in the theatre, the training received, and the particular experiences lived. This has been done by reporting the words of soldiers who took part in missions in asymmetric warfare environments. It is a procedure that may perhaps have done harm to an organic treatment of the individual topics addressed, but that made it possible to preserve the liveliness and spontaneity of the expressions. The reader is thus left with the task (and the pleasure) of extrapolating the recounted experiences and linking and connecting them with each other in order to form a personal framework of comprehension of the examined environment.

9 Ebbe Blomgren, "Is Military Praxis in International Missions Reforming the Profession?" in The Heritage and the Present: From Invasion Defence to Mission Oriented Organisation, ed. Alise Weibull and Bengt Abrahamsson (Karlstad: Swedish National Defence College, 2008), 233-42; Giuseppe Caforio, ed., The Flexible Officer: Professional Education and Military Operations Other Than War, A Cross-National Analysis (Gaeta: Artistic \& Publishing Company, 2001). 



\title{
Europe's Armed Forces in Civil Security
}

\author{
John L. Clarke *
}

\section{Introduction}

Two decades after the end of the Cold War, does Europe need armies? What should soldiers do, besides fighting and preparing to fight? What tasks are (and are not) appropriate for soldiers to carry out in a domestic context? Is territorial defense still a valid mission for European armed forces? And are there better-and cheaper-solutions?

These questions have become increasingly difficult to answer in the current strategic and budgetary environment. Armies are expensive, and the threat environment for most European countries has evolved significantly over the past two decades. As a consequence, taxpayers may look askance at defense expenditures, wondering why it is still necessary to pay so much for a capability that no longer seems necessary and might even be redundant. Those defense expenditures also represent tempting targets for politicians anxious to cut budgets in times of austerity.

This study is intended to help examine these issues, with a view towards trying to provide answers to the questions of what armies (and, by extension, navies and air forces) can do, should do, must do - and, equally important, should not do - particularly in a domestic context. With the tremendous pressures on governments to save money, these questions are likely to become even more salient in the near future.

For armies are convenient targets, and relatively easy to cut. In most European countries, defense expenditures are discretionary, unlike entitlement programs. Their constituencies - though often powerful, particularly in the defense industry - are small, and military forces, particularly contemporary professionalized forces, lack significant popular support. Absent a sense of external threat, militaries are often unappreciated. These professional armies, as is the case in most European countries, are generally small and have little lobbying power and few friends in high places. They are vulnerable. But they are also available, for what often seems to be whatever task comes up.

Thus, "Let the army do it" is a phrase often heard in many countries when a tasksuch as the recovery from an earthquake-exceeds the abilities of local and regional, and often even national, authorities. Military forces are often seen, justifiably or not, as sitting in their bases, waiting for something to do. And since engaging the military in a civil security task is often viewed as free of both cost and risk, the temptation on the part of political leaders to "let the army do it" is great indeed. And it must be said that, for many tasks, it is appropriate to "let the army do it" - but not for all tasks at all times.

This trend toward having military forces perform ever more and varied functions distinct from their traditional tasks associated with territorial defense is present in

\footnotetext{
* Dr. John L. Clarke is the Director of the Program on Civil Security at the George C. Marshall European Center for Security Studies in Garmisch-Partenkirchen, Germany.
} 
every state with an army. Indeed, some countries, such as China and Egypt, have armies that are vertically and horizontally integrated into the economy, often running major business enterprises. But armies are often asked to perform more mundane tasks, such as trash collection and firefighting, often to the detriment of their readiness to carry out their primary function. For while there are benefits to the engagement of military forces in civil support tasks, there are also opportunity costs. Soldiers engaged in these tasks cannot often be rapidly redeployed. They cannot be in two places at one time, and often would require a significant amount of time to extricate themselves from a particularly challenging civil support task in order to carry out another one. Moreover, soldiers, particularly contemporary professional soldiers, are expensive, particularly when compared to conscript soldiers.

Military forces have traditionally played broad - indeed, quite expansive-roles in support of European governments, particularly when viewed from the U.S. perspective, which is characterized by legal and cultural restraints on the domestic deployment of military personnel. Military forces, particularly ground forces, have often provided key support to governments, and in more than a few cases have supplanted them. This article will review this European tradition, with a view towards establishing a basis for examining the current trends in European defense support to civil authorities, with a focus on the post-World War Two period. Tracing the development of the domestic engagement of European armed forces over three distinct phases, it will examine the range of tasks assigned to the armed forces in the domestic environment through the cultural prism of a number of European states, with special emphasis on the case of Italy.

\section{The Pre-War Tradition}

It is useful to review the role of military forces in the domestic environment in the period preceding World War Two, as it provides insights into the role of the military and how both political leaders and the senior military leadership itself have perceived it. In the period following the First World War, the armed forces of many European countries (with the notable exceptions of Germany and Great Britain) were extensively involved in domestic politics and support of political movements, when not actually constituting a political movement of their own. Soldiers and former soldiers, as well as leaders of militarized political movements (the Fascist movements in Italy and Spain come to mind) played leading, indeed dominant, roles in the politics of those countries.

This trend was evident in other European countries as well. Following the Russian Civil War, the Red Army came to play a highly significant role in support of the Communist Party in the new Soviet Union; similarly, the Austrian militias played supportive roles in the events leading up to the civil war there in February 1934. And the monarchies of the Netherlands, Belgium, Sweden, and others were highly dependent on their armed forces for maintaining domestic order during the interwar period.

Likewise, military forces in the United Kingdom were involved in extensive domestic actions, most notably their heavy involvement in Ireland, in which the British Army, along with locally recruited forces such as the Black and Tans, conducted a 
bloody counterinsurgency campaign against Irish insurgents fighting for the liberation of Ireland from British rule. ${ }^{1}$ The British Army was also involved in many other domestic contingencies, notably the bloody suppression of industrial action by trade unions in 1926, an action similar to the eviction of the Bonus Army in Washington in 1932. ${ }^{2}$ And the role of the British Army in Ireland was a textbook case of the involvement of military forces in dealing with domestic counterinsurgencies, with all the negative aspects of that involvement playing a prominent (if undesirable) role.

Even republican France saw the military play a major role during the interwar period. Military expenditures, notably for the construction of the Maginot Line, were the single largest budget item in the budgets of interwar France. And the veteran's movements, many of them organized along military lines, played prominent, indeed often dominant, roles in French politics, frequently agitating for increased spending on military projects. In Italy and Spain, Fascist governments did not hesitate to employ their armed forces in a wide range of domestic operations, many of them designed to enforce their laws and, not coincidentally, preserve the government. Only in Germany, with its demilitarized Reichswehr, did the military not play a significant domestic role during the interwar era, at least initially. But even here, militarized political movements, such as the Brown Shirts and Communists, were important actors in the German political arena.

Of course, the rise of Adolf Hitler, supported by both the Sturmabteilung (SA), the paramilitary wing of the Nazi Party, and the Schutzstaffel (SS), the party's security detail, provides an excellent example of the militarization of politics. Hitler's rise to power, and exercise of it after 1932, was militarized in the extreme. The employment of private armies, such as the SS and SA, led to a highly militarized political culture in Germany, where nearly all political figures wore uniforms and the military regained an important voice in the political affairs of the nation. This was echoed by the victory of the Blue Shirt movement under Franco in Spain and the rise of Mussolini's Fascists in Italy. The army, if not in charge of the nation, was at least one of the major players.

\section{Cold War Contributions}

With the end of World War Two and the defeat of the Axis powers, militarized politics seemed to be defeated as well. With the exception of General Franco in Spain, and later the Portuguese generals under Salazar, the role of the military in politics receded in many countries, at least in Western Europe (the role of the Soviet Army in bringing Communist governments to power in Eastern Europe is a story that is more properly

1 Michael Head and Scott Mann, Domestic Deployment of the Armed Forces: Military Powers, Law and Human Rights (Farnham, U.K.: Ashgate, 2009), 83; Jonathan Stevenson, "The Role of Armed Forces of the United Kingdom in Securing the State against Terrorism", in Armies in Homeland Security: American and European Perspectives, ed. John L. Clarke (Washington, D.C.: National Defense University Press, 2006), 23-24 and 29; and Peter Taylor, Brits: The War against the IRA (London: Bloomsbury, 2001).

2 Head and Mann, Domestic Deployment of the Armed Forces, 83. 
told elsewhere). But there was a significant interregnum: the military governments in occupied Germany and Austria.

These governments, although intended initially only as an interim solution, came to provide an intellectual basis for the appropriate role of military forces in stability operations that resounds even today. The development of a corps of Allied uniformed civilian government specialists charged with overseeing the rebuilding of those shattered economies was an innovation. The range of tasks and functions assigned to these operatives in societies that had been reduced to their bare minimum functional levels was comprehensive, ranging from the provision of essential services to the re-establishment of pre-war liberal institutions, such as a free and open media and the role of non-governmental organizations, such as Rotary Clubs. Of course, both the West German and Austrian political environment were completely demilitarized. Indeed, it took the better part of a decade to reestablish the military as a legitimate part of society in those countries. ${ }^{3}$

The role that these officers and soldiers played in the re-establishment of civil society in the heart of Western Europe is often overlooked today - but it provided prima facie evidence that armies are capable of playing an important role in this process, at least in an environment of occupation, and anticipated the developments in Iraq and Afghanistan in the past decade. Military government officers, now referred to as "civil affairs specialists," are key players in the broad range of stability and reconstruction operations that are under way around the globe.

One other aspect of military involvement in government in the immediate post-war era is worthy of comment. The role played by French military forces in suppressing the liberation movement in Algeria in the 1950s is very significant. At that time, Algeria was a part of metropolitan France - that is to say, it was considered French sovereign territory, not a colony or overseas possession. Thus, the campaign in Algeria is best regarded as a domestic counterinsurgency operation, with all its attendant challenges. The irony of France's campaign there is that, while the counterinsurgency campaign waged throughout the country and the counterterrorist campaign conducted in the major cities such as Algiers were largely successful in suppressing the insurgency, the campaign foundered on the highly negative public perception of the manner in which it was conducted and the successful internationalization of the Algerian liberation movement.

This campaign had a marked effect on the French Army in its aftermath. The high degree of politicization of the general officer corps - combined with the extremist political views of many in the Foreign Legion and other elite units of the French Army, which found their ultimate expression in the development of the Organization de L'Armée Secret (a dissident French paramilitary/terrorist organization formed in Fascist Spain and dedicated to preventing Algerian independence)—was to have long-

3 See Gerhard J. Klose, "The Weight of History: Germany's Military and Domestic Security," and Johann Frank, "A Neutral's Perspective: The Role of the Austrian Armed Forces in Homeland Security," in Armies in Homeland Security: American and European Perspectives, ed. John L. Clarke (Washington, D.C.: National Defense University Press, 2006). 
lasting and detrimental effects on the French Army and its relationship to society. Moreover, the conduct of the Algerian campaign itself, with the widespread application of torture, did the public image of the French Army no favors. ${ }^{4}$

Western European military forces, as they built up their capabilities under the aegis of NATO and in response to the growing Soviet threat, performed a number of other decidedly non-military tasks in the 1950s and 1960s. One of the more interesting and instructive was the role of the Swedish armed forces in the switch from left-hand driving to right-hand driving on Swedish roads. In 1963, Sweden decided to switch from driving on the left, as in the U.K., to the right side of the road. This was done because the great majority of automobiles in Sweden had their steering wheels on the left, as was the case with most Continental cars. Despite public opposition (nearly 83 percent of the population voted against the switch), the Swedish government ordained the change, and it was scheduled for the night of 3 September 1967. Overnight, traffic across Sweden switched sides - aided by the Swedish Army, which was mobilized to facilitate the transformation (including the reversal of traffic signs and signals). Swedish soldiers provided much of the traffic control force dedicated to this effort. ${ }^{5}$

During the Cold War, most Western European armies were fully preoccupied with their homeland defense tasks, but were frequently assigned to support law enforcement organizations, particularly in anti-terrorism efforts. In some countries, such as the U.K., this took the form of a domestic counterinsurgency campaign. Indeed, the British Army exercised primacy in Northern Ireland operations from 1970 until 1976, a period in which the police in that province were unable to assert full control. The army's experience in this operation was decidedly less than positive, and major efforts were made to finally restore police primacy by mid-decade. ${ }^{6}$

Of course, military forces in some countries in Western Europe were actively engaged in efforts to combat terrorism. Many armies developed specialized units focused on a domestic counterterrorism role, most notably the British Special Air Service, which continues to this day to play a prominent part in domestic counterterrorism operations. ${ }^{7}$ Likewise, the French Army's VIGIPIRATE operation, first launched in the early 1990s, has placed military units in support of law enforcement organizations in protecting key assets, as well as conducting counterterrorism operations in French

4 Denis Vaultier, "The Military's Role in Homeland Security in France," in Armies in Homeland Security: American and European Perspectives, ed. John L. Clarke (Washington, D.C.: National Defense University Press, 2006), 211.

5 See The Volvo Owners Club, September 3 1967: 40 years of Driving on the Right Side in Sweden (2007); available at www.volvoclub.org.uk/history/driving_on_right.shtml.

6 Head and Mann, Domestic Deployment of the Armed Forces; Stevenson, "The Role of Armed Forces of the United Kingdom in Securing the State against Terrorism"; and Taylor, Brits: The War Against the IRA.

7 See the website of the elite U.K. Special Air Service (SAS) at www.army.mod.uk/ specialforces/30603.aspx. See also Stevenson, "The Role of Armed Forces of the United Kingdom in Securing the State against Terrorism," 28. 


\section{THE QUARTERLY JOURNAL}

overseas territories. ${ }^{8}$ The Italian military also conducted numerous such operations, particularly against the Red Brigades in the 1970s and 80 s. $^{9}$

In addition to numerous antiterrorism operations conducted during this period, many European armies were frequently employed in humanitarian assistance and disaster relief (HA/DR) operations across a broad spectrum of responses to both natural and man-made disasters. The operations of the German and Austrian armed forces in response to floods on the Rhine, Oder, and Danube Rivers represent but a few of these operations. ${ }^{10}$ The Italian Army's response to a chemical plant disaster in 1976 in Seveso, north of Milan, and a landslide above the Vajont Dam in 1963 are also representative. ${ }^{11}$ Other examples would include fighting forest fires in France and Greece, as well as maritime responses to oil spills in France and Spain. ${ }^{12}$

In the context of this article concerning the European tradition of military operations in domestic contingencies during the Cold War era it is worth citing the Warsaw Pact experience as well. Though markedly different, the prominent role enjoyed by the military and security services of many Eastern European states resulted in highly militarized societies with numerous paramilitary organizations, such as the Kampfgruppen der Arbeiterklasse in the former East Germany. These organizations existed to supplement the regular military forces in these states and also served to reinforce the state security apparatus. The role of the military forces in crushing uprisings against Communist rule in Hungary in 1956 and Czechoslovakia in 1968, as well as the imposition of martial law in Poland in 1980-81, offers object lessons with regard to the dangers posed by the military playing an overwhelming role in domestic politics.

8 Statement by Jean-Pierre Raffarin, Prime Minister of France, "Présentation du nouveau plan gouvernemental de vigilance, de prevention et de protection face aux menaces d'actions terroristes: Vigipirate," (26 March 2003), Service d'information du Gouvernment; available at www.vaucluse.gouv.fr/IMG/pdf/plan_vigipirate-2.pdf. See also Denis Vaultier, "The Military's Role in Homeland Security in France," 206-7, 213, 216, 219, 226.

9 See Carlo Cabigiosu, "The Role of Italy's Military in Supporting the Civil Authorities," in Armies in Homeland Security: American and European Perspectives, ed. John L. Clarke (Washington, D.C.: National Defense University Press, 2006).

10 The military provided assistance during the flooding of the Rhine in 1993, of the Oder in 1997, and of the Danube in 2002, see Informationsplattform Undine, "Das Hochwasser der Oder in Sommer 1997," available at http://undine.bafg.de/servlet/is/15719/; and "Das Weihnachtshochwasser des Rheins 1993," available at http://undine.bafg.de/servlet/is/ 19295/. See also City of Vienna, "Hochwasser 2002," available at www.wien-vienna.at/ geschichte.php?ID=829.

11 Cabigiosu, "The Role of Italy's Military in Supporting the Civil Authorities," 95.

12 European Commission Directorate-General Joint Research Center, Institute for Environment and Sustainability Land Management Unit and Directorate-General Environment Forests Unit, "Forest Fires in Europe. 2003 fire campaign," European Communities Report 4 (Rome: European Communities, 2004); Secrétariat d'état aux transports \& à la mer: Inspection générale des services des affaires maritimes - Bureau enquêtes et accidents, Perte totale suite à avarie de coque du pétrolier bahaméen Prestige survenue dans l'ouest de la Galice. 13-19 Novembre 2002 - Contribution provisouire au rapport d'enquête technique (Paris: Secrétariat d'état aux transports \& à la mer, 2003). 


\section{Post-Cold War Tasks for Soldiers}

With the fall of the Soviet Union and the end of the Cold War, followed by the emancipation of the states of Eastern Europe, the military forces in Europe, both East and West, began a process of retrenchment as states took advantage of this interregnum to cash in on the so-called "peace dividend." This resulted in major declines in the numbers and kinds of military forces that were available not only for national defense but also for service in domestic contingencies. This coincided with an apparent rise in the numbers and kinds of contingencies that required military participation. Floods, earthquakes, and other natural catastrophes seem to have increased in both their frequency and their intensity over the past twenty years, necessitating an enhanced response. Since this has also coincided with a decline in resources available to response efforts, much of that burden has fallen on eviscerated military forces.

Natural disasters, such as floods in the United Kingdom, earthquakes in Italy, major windstorms in France, and bird flu in Germany are representative of this trend. ${ }^{13}$ But an even greater impetus for the domestic engagement of military forces has been the response to the terrorist attacks of 11 September 2001 in New York City and Washington, D.C., and the subsequent attacks in London, Madrid, and elsewhere in Europe over the ensuing decade.

The perceived necessity to provide increased levels of security, often within a constrained budget environment, has led to increased reliance on military forces to provide significant, if not major, elements of that response. In many European countries, soldiers can be seen guarding critical infrastructure, government buildings, and key tourist sites, often in full combat uniform and armed with assault rifles. The presence of French soldiers at the Eiffel Tower in Paris, or Italian soldiers guarding diplomatic missions in Rome, are emblematic of this increased military response to terrorism. The passage of enabling legislation (such as the Civil Contingencies Act of 2004 in the U.K.) has also made it easier, and thus more convenient, for political leaders to call upon military forces in response to the need for increased domestic security.

The European tradition of engaging military forces-including active, reserve, and paramilitary organizations - in domestic contingencies is well established. While there are notable exceptions, including Germany (and, to a lesser extent, Austria), many European states exhibit considerably less reluctance than in the past to call upon military forces to carry out a broad and, it would seem, increasing range of operations on their home soil. The next section of this article will analyze one such country, Italy, in

13 John Hammond, "Floods 'to become more frequent'," BBC News (19 August 2004); Paul Lewis, "Background: Italy and earthquakes. With geological faults running up its spine, Italy is prone to earthquakes - although rarely as destructive as in Abruzzo today," The Guardian (6 April 2009); Lizzy Davies, "Fatal storm sweeps through France. At least 40 killed as hurricane-force winds and torrential rains bring flooding to central and western France," The Guardian (28 February 2010); "German Military Joins Fight Against Bird Flu," Deutsche Welle (18 February 2006), available at www.dw.de/german-military-joins-fight-against-birdflu/a-1908444. 
detail, as it may be seen as a harbinger of the type of domestic demands that will be placed on military forces in the future. The balance of this article will examine what those demands are likely to be.

\section{Italy: A Case Study of Armies in Civil Security}

European civilian leaders are increasingly looking to their military forces to provide an ever-increasing range of services in the domestic arena. But this trend is not new. As noted in the previous section, European states have a rich history of employing military forces in domestic contingencies. This section will focus in particular on Italy, which has been unusually creative in its approach to having soldiers do the job - whatever the job is. Of course, each country in Europe has a different tradition in this regard. They have different national security organizations and strategies, and they have different perceptions of the threats and challenges to their domestic security. Each nation approaches these challenges in a different manner reflecting their unique histories and the status of the armed forces in their respective states. In this regard, Italy can be especially instructive, given the rich tradition, unique legal structure, and exceptionally diverse engagement of Italian military forces within Italy.

Italy has a long history of engaging its military forces in domestic contingencies. The relative ease with which successive Italian governments have turned to the military to carry out safety and security tasks makes Italy an ideal case study for determining the extent to which European governments may see military forces as acceptable substitutes for properly constituted domestic security forces. Italian governments have not hesitated to use soldiers to carry out domestic security tasks and, in some cases, to endow those soldiers with special police functions and powers.

Italian armed forces have participated in a broad range of civil support operations since the end of World War II, ranging from protecting key facilities and critical infrastructure to providing relief in response to natural disasters. Since 1992, but particularly since 2001, the Italian armed forces' role has expanded significantly, to the extent that the Italian military now undertakes a greater range of domestic security tasks than that of any other European country.

Italy does not use the homeland security concept per se, but rather employs a concept known as "presence and surveillance." This concept has three operational domains: territorial defense, disaster relief, and territorial control. The first two of these correspond to the U.S. concept of Homeland Defense and Civil Support, but the third, territorial control, has no exact equivalent in the U.S. Many of the Italian military's post-war domestic operations have been conducted under this rubric, which envisions Italian military forces conducting law enforcement-like activities. ${ }^{14}$

Italian law views the military as a full partner in many kinds of domestic contingencies. Under the law that established the Agency for Civilian Protection (225/92), the armed forces are designated as the "operational branch" of the national civil protection service. While this organization is primarily concerned with coordinating Italy's re-

14 Cabigiosu, "The Role of Italy's Military in Supporting the Civil Authorities," 113-15. 
sponse to disasters, it has become increasingly involved in working with security organizations to enhance public security. ${ }^{15}$

This history includes the stationing of thousands of Italian soldiers in the South Tirol in the 1960s in response to a separatist terror campaign designed to restore the South Tirol to Austria. ${ }^{16}$ These soldiers carried out missions to protect critical infrastructure such as power lines, as well as helping to seal the border with Austria to prevent cross-border infiltration. Soldiers performed similar functions in the 1970s throughout Italy to secure facilities such as rail infrastructure against possible attacks by the Red Brigade terrorist group.

Likewise, Italian Army units have been very active in disaster relief operations in earthquake-prone regions of Italy, most notably in the Vajont Dam disaster in 1963, in which over 3000 people died in the wake of a landslide into the Vajont reservoir, and the earthquake in Friuli in 1976, which killed a thousand and left over 150,000 homeless. ${ }^{17}$

In 1992, acting in response to the murders of two Italian prosecutors fighting the Mafia in Sicily, the Italian government decided to reinforce the law enforcement presence in the region by deploying nearly 10,000 soldiers to Sicily in an operation called Vespri Siciliani (or "Sicilian Vespers," evoking the Verdi opera of the same name). This operation employed soldiers to conduct territorial control operations throughout Sicily, including surveillance operations, patrols, checkpoints, and infrastructure security operations. The operation concluded in 1998. Over the six years of the initiative, the Italian Army checked nearly a million persons and 665,000 vehicles, and arrested 1225 persons. During this time, all nineteen brigades of the Italian Army were deployed to Sicily on a sixty-day rotational cycle. The average strength of the army in Sicily during this operation was about $6000 .^{18}$

Of significant importance was that, for this operation, soldiers were designated by an act of parliament as "public security agents," which entrusted them with law enforcement powers, including the authority to detain and arrest suspected persons. This enabled army units to act independently of police and Carabinieri units. At the same time, soldiers required significant training in order to carry out police functions, particularly with regard to the use of force. Italian law sets forth three categories for law enforcement agents: full police authority, public security agency, and a "reduced" public security function. Soldiers employed in the Vespri Siciliani operation enjoyed public security agency authority. ${ }^{19}$

15 Presidenza del Consigli dei Ministri Dipartimento della Protezione Civile, "The Italian Civil Protection National Service" (Rome: Department of Civil Protection); available at www.protezionecivile.gov.it/cms/attach/brochuredpc_eng2.pdf.

16 Cabigiosu, "The Role of Italy's Military in Supporting the Civil Authorities," 95.

17 Ibid., 95-96.

18 Ibid., 99; Head and Mann, Domestic Deployment of the Armed Forces, 106.

19 Italian Ministry of Defense, "Operation 'Vespri Siciliani'," at www.esercito.difesa.it/enUS/Activity/Operationsonthenationalterritory/Pages/OperationVespriSiciliani.aspx. 
Also in 1992, the Italian government commenced Operation Forza Paris, a similar operation of lesser scale in Sardinia, where Italian Army units conducted operations in the rugged central portion of the island. This operation, which lasted about two months and involved up to 5000 soldiers, was designed to demonstrate the government's will to maintain control over its territory, particularly difficult to reach areas that might today be called "ungoverned spaces." It was also designed to reduce the freedom of action of local criminal groups. ${ }^{20}$

During Forza Paris, Italian Army units conducted military training operations in the central portion of the island, including live-fire training and forced marches. Unlike units deployed in Sicily, these troops did not have special police powers. Rather, these operations were designed to demonstrate "presence" and thus discourage criminal activity. In addition to combat training, military engineers carried out a number of operations, such as road repair and water purification efforts. ${ }^{21}$

Later in the decade, as the violence in the Balkan region continued to increase, Italian military units were pressed into service in support of the Guardia di Finanza's mission of securing Italy's external borders. These efforts included Operation Testuggine, an army operation to control illegal immigration along Italy's land border with Slovenia, and Operation Salento, a similar effort to control illegal maritime immigration along Italy's southeast coast. Testuggine involved an average presence of 4000 soldiers, while Salento averaged 650 soldiers. Both operations involved endowing soldiers with limited police powers, which enabled them to stop and arrest suspects. ${ }^{22}$

With the end of the decade, and the advent of the War on Terror era brought on by the attacks of September 2001, the range of tasks given to the military continued to grow. In October 2001, the Italian Army commenced Operation Domino. This operation, involving up to 4000 soldiers, was designed to provide protection for 150 installations considered to be critical elements of the nation's infrastructure and thus possible targets of terrorist attack, a list which included airports, railways stations, water treatment plants, power generation facilities, and telecommunications sites. It also included increased security for foreign (mainly U.S.) military bases in Italy. In contrast with other operations, the military did not possess special police powers, and thus could not, on their own, stop and arrest suspects. Rather, they were required to have police officers (either state or Carabinieri) accompany army patrols in order to do this. The operational tempo of Domino was reduced after 2006, but some facilities still enjoy enhanced protection. ${ }^{23}$

In the latter part of the decade, the tempo and scope of domestic military involvement in Italy increased again. In addition to a number of operations designed to support police operations (such as the assignment of 2500 military personnel to carry out general security tasks and to provide emergency medical capabilities at the 2006 Turin

\footnotetext{
${ }^{20}$ Cabigiosu, "The Role of Italy's Military in Supporting the Civil Authorities," 99.

21 Ibid.

${ }^{22}$ Ibid., 99, 113-14.

23 Ibid., 100-1.
} 
Winter Olympic games, as well as to provide external security for the 2009 G8 meeting in L'Aquila), Italian military units have been assigned an ever-widening set of tasks.

In response to a perception that the overall security situation in major Italian cities had deteriorated, the Berlusconi regime once again turned to the military, this time to provide enhanced security in Italy's urban streets. Operation Strade Sicure ("Secure Streets") commenced in May 2008 by executive decree, later authorized by law number 125 of 24 July 2008. This operation was designed to support police and Carabinieri units by increasing the presence of security forces on Italian streets. Specific tasks include ensuring the external security of immigration centers in sixteen provinces (involving about 1000 soldiers); securing fifty-two sensitive locations in Rome, Milan, and Naples, mostly embassies and consulates (involving 750 soldiers); and joint police-army patrols in nine cities (involving 1500 soldiers), as well as a command and control and logistics element of about 300 soldiers. $^{24}$

Like previous operations, these soldiers have some law enforcement powers, limited to stopping and searching suspicious individuals. Such individuals must be immediately turned over to law enforcement authorities, hence the joint patrols with police/ Carabinieri officers. These joint patrols are carried out in high-traffic areas, such as bus and train stations, as well as in major tourist areas (for example, the Forum in Rome). In the first year of operation, it resulted in searches of nearly 300,000 people and 150,000 vehicles.

The second major operation launched in 2009 was Operation Strada Pulite ("Clean Streets"). Italy has a long history of organized labor action, including the refusal of sanitation workers to remove garbage. In response to the growing mountains of refuse in the streets of Campania province (Naples), Prime Minster Silvio Berlusconi authorized the province to call upon the armed forces to remove the waste material. This authority was later reinforced by Law $125 / 09$, which identified waste treatment sites as "areas of national strategic interest." This law called for an end to this status at the end of 2009 , though it was subsequently extended. ${ }^{25}$

Of note is that this operation not only included efforts undertaken to relocate the refuse to waste storage and treatment sites, but also to guarantee the security of those same sites. This is because there was much local political resistance to the establishment of these sites in the area surrounding Naples, and thus it became necessary to "guard the garbage." Another aspect of the effort was the necessity to inspect the waste material for contaminated materials, particularly radioactive materials. The operation has involved an average of 700 soldiers on a daily basis, and resulted in the removal of nearly 40,000 tons of refuse, as well as the inspection of over 110,000 trucks. $^{26}$

24 Italian Ministry of Defense, "Operation 'Strade Sicure'," available at www.difesa.it/EN/ Operations/NationalOperation/Pagine/OperationStradeSicure.aspx.

25 Matilde Maisto, “Operazione 'Strade Pulite': Cambio al Comando fra Ufficiali della Garibaldi. Cuofano Lascia il Posto a Mirra," Cancello ed Amone News (16 February 2010); Italian Ministry of Defense, "Operation 'Strate Pulite'."

26 Maisto, "Operazione 'Strade Pulite'.” 
One last recent operation deserves mention. On 6 April 2009, a major earthquake struck the Abruzzi region near the city of L'Aquila, resulting in 300 deaths and 1500 injured, as well as vast damage to property. This earthquake created an urgent need for disaster relief operations. The armed forces deployed over 1300 troops as well as large numbers of vehicles and helicopters to the region to assist in this effort in direct support of the Civil Protection Agency. ${ }^{27}$

The Italian public's reaction to most of these operations has been uniformly positive. The population has generally concurred with the decision to deploy soldiers to carry out these non-military tasks; indeed, on occasion, there have been demonstrations in favor of more military involvement, as the armed forces are now seen in Italy as an organization that "gets things done." Of course, the political benefit to those leaders responsible for ordering the military to undertake these tasks does not go unnoticed. Perhaps surprisingly, the military also takes a very favorable view of these operations. While many senior officers recognize the opportunity cost involved in deploying soldiers on these missions, they often voice support for them. This can be attributed to a number of factors.

First, these operations are believed to enhance the image of the military in Italy, where the armed forces have historically not generally been viewed as highly competent. As in many countries, the armed forces are often perceived as inactive, since the general public does not view training activities as "real" work. Frequently, the military is thought to be sitting in their barracks, waiting for something to do. This perception is often reinforced by the soldiers themselves when they are asked to recount how they spend their time. As a consequence, the public fails to appreciate the importance of force readiness, and comes to value the military only when they visibly carry out operations. This is particularly true in Italy, which long had a conscript military and which has many other security organizations (police, Carabinieri, Guardia Di Finanza, etc.) with which the military must compete for public approval and funding.

Second, the senior military leadership views these operations as a form of training. For example, the deployments to Sicily and Sardinia in the early 1990 s represented the first time the Italian military really had to deploy ground forces in this part of Italy; up to that point, the army had been principally concentrated in the northeastern corner of Italy. The Italian military learned a great deal about deployments, which was put to good use when Italy deployed forces to the Balkans in the mid-1990s.

Third, as many of these operations resembled in some manner the stability and reconstruction operations carried out as part of the many peace operations in which the Italian armed forces have participated around the world, leaders have come to view these operations as an excellent method of preparing for these deployments. In particular, they note the ability to operate in urban terrain and the close contact with civilian populations as having very close parallels with stability operations, as well as increased skills in patrolling and conducting checkpoint operations.

27 "Powerful Italian quake kills many," $B B C$ News (6 April 2009); "Italy scientists on trial over L'Aquila earthquake," BBC News (20 September 2011). 
Finally, senior leaders acknowledge that, in a constrained budget environment, these operations can provide a useful source of funding, which can be used to train personnel and units for other operations. The Italian military lacks sufficient funding to carry out training exercises for its full range of tasks. By participating in these domestic operations, the military can procure additional funding that may be used for this purpose.

Thus, it is no surprise that both the public and the government take a favorable view of these operations. It is therefore reasonable to anticipate that the government will continue to look to the military to provide a growing range of support to law enforcement, as well as engage in civil support operations of increased scope, including the possibility of providing essential services, such as water purification or trash removal. But it is also reasonable to ask if these operations are best carried out by the military, or whether it would be more efficient to further develop the capabilities of other organizations, such as the Carabinieri, to conduct them. ${ }^{28}$

In this regard, it should be noted that there are increasing tensions between the Carabinieri and the other branches of the Italian armed forces, particularly the army. Over the past few years the Carabinieri-Italy's military police force - has grown in size to a point where it challenges the army, and competes with the other armed forces for resources. Italian military leaders are quick to stress the legal status of the Carabinieri as part of the Italian armed forces, but increasingly the Carabinieri has acted in an independent manner, preferring to emphasize its ties to the Ministry of the Interior.

The array of tasks that political leaders feel comfortable having soldiers perform continues to grow in both scope and number. Particularly in states with largely conscript forces, the temptation is great to engage those soldiers in civil security tasks. While many of those tasks are indeed appropriate for military forces to perform, some simply are not. The Italian example provides us with an unusually rich history of these tasks, and presents some salient lessons for security planners who may be thinking, "Why not have the army do it?" If the Italian experience is any guide, political leaders will become increasingly creative in formulating requests for the military to do just that.

\section{Conclusion}

Does Europe need soldiers? To what end? These questions are likely to come into sharper focus as the twin dynamics of a lack of an external threat and increased budgetary pressures take hold. For, strategically speaking, Europe is at a crossroads. Few, if any, members of the European Union or NATO are confronted by an external military threat; hence the need to maintain large (or even small) standing armies has declined. Similarly, the likelihood that European nations will deploy large numbers of soldiers overseas in operations similar to those conducted over the last two decades in places

28 Italian Ministry of Defense, "Carabinieri," available at http://www.carabinieri.it/Internet/ Multilingua/EN. 
such as Kosovo, Bosnia, Iraq, and Afghanistan is also likely to decline, if only due to a lack of wherewithal, if not a lack of will. Does Europe need armies? If so, what should they do?

The trends governing European responses to these dynamics are quickening, and disturbing. European nations have already reduced their active and reserve military forces far more than is generally appreciated, and have failed to invest in newer capabilities and technologies to the extent necessary to maintain effective armed forces. Many European states have decreased their forces to the point where they are no longer capable of mounting a credible defense of their territory. And reserve forces, once the pivot of a mobilization strategy, have nearly disappeared. But given the realities of threats and budgets, how could this be otherwise?

If, as has been posited in this article, civil leaders will find ever more tasks for their armed forces, and the leaders of those forces continue to agree to take on these tasks, and even suggest some on their own, a state may find itself in the position of having a very expensive, improperly equipped, and overqualified emergency response instrument instead of a functional military force. The interests of senior military leaders in preserving the end strength of their forces may compel them to agree to such requests for domestic assistance more often. As the dynamics of the current era of fiscal difficulties proceed, they will find it ever more difficult to decline. Yet, at some point, they must find the courage to do so, lest their armies turn into public works entities. Armies, as robust as they often are, can be fragile things if they are not used in the way they were designed. Their great flexibility ought not to be used as an instrument of their own destruction. European nations' tradition of engaging soldiers in these tasks is instructive not only because it delineates what can be done, but also because it helps leaders decide what ought not be a soldier's job. 


\title{
NATO’s Energy Security Policy Put to the Caspian Test
}

\author{
Nathan R. Grison*
}

\section{Introduction}

As a bridge between the Middle East, the former Soviet republics, and the Euro-Atlantic zone, the Caspian Sea is increasingly at the center of the global geopolitical and commercial game. In addition to its strategic location, the Caspian Sea, according to analysts, could contain between 6 and 10 percent of the world's gas reserves, and from 2 to 6 percent of the world's oil reserves.

Defined in 1921 as an Irano-Soviet sea, the Caspian rapidly became a source of tension after the fall of the USSR. The increased number of littoral states, rising from two to five, made it necessary to redraw national sea borders and, maybe even more importantly, to redistribute the ownership of the resources lying under the Caspian seabed. As a regional agreement was never reached, each country has started granting permits for the extraction of hydrocarbons in what it considers to be its territorial waters. These conflicting claims recently led to a generalized and alarming military buildup across the region. As a result, in the past several years a number of armed incidents have been reported that have contributed to further destabilizing an already volatile region.

Moreover, this situation can have an impact on the energy security of NATO member states, and in particular those members of the European Union (EU), as they seek to diversify their sources of oil and gas supply. Their traditional hydrocarbon-exporting partners show signs of slowing down production, while consumption in the EU is expected to increase in the next decade. Some resource-rich countries could try to take advantage of this European dependency on their exports. In this regard, the 2006 gas crisis represented a wake-up call. With "fracking" developing rather slowly on this side of the Atlantic, Europe's dependency on Russian hydrocarbons should be balanced with new sources of supply. ${ }^{1}$ As expressed in the 2010 Common Strategy and 2012 Chicago Declaration, energy security is on the Alliance's agenda.

This article will argue that, although NATO has listed energy security as one of the main emerging security challenges the Alliance will face in the future, the example of the Caspian region highlights the difficulty for the Alliance in being active in the energy security domain, especially in a region where all the players are Partners or nonPartners and have their own security agenda. Moreover, translating the agreed language of the 2012 Strategic Concept into concrete actions is also difficult for the Alli-

Nathan R. Grison is Research Fellow at NATO Parliamentary Assembly. He holds Bachelor's degree in Political Science and Government and Master's degree in International Relations from the Institut d'Etudes politiques de Paris/ Sciences Po Paris.

1 Brad Plumer, "How Long Before Fracking Spreads to Europe? A Decade, at Least," The Washington Post (7 February 2013); available at http://www.washingtonpost.com/blogs/ wonkblog/wp/2013/02/07/will-fracking-ever-spread-to-europe-maybe-in-a-decade/. 
ance because the political will and the means of NATO member states necessary for the Alliance to become actively involved in this region are very limited. As a result, other international organizations, such as the EU and the Organization for Security and Cooperation in Europe (OSCE), have taken the lead in the area of energy security. The current militarization of the littoral states and the growing instability in the region, however, raise the question of the role NATO wants to play and where it could add value in the first place.

\section{The Caspian's Unsettled Legal Status}

Until the breakup of the Soviet Union, the Caspian Sea was exclusively and equally shared by Iran and the USSR as stated in treaties signed in 1921 and 1940 by the two countries. At the beginning of the 1970s, the Soviet Ministry for Oil and Gas Industry divided its share of the sea into four regional zones belonging to the littoral republics: Azerbaijan, Kazakhstan, Russia, and Turkmenistan. When the USSR disintegrated and these republics became independent, the geopolitical environment of the entire region was radically modified. The number of states owning a share of the Caspian littoral increased from two to five, with the three new littoral states not recognizing the previous treaties (to which they were not signatories). The main energy deposits being located outside the Russian share of the seabed, Moscow first backed the idea of creating a consortium to equally exploit and share Caspian resources. On their side, the three new independent states called for the sea to be divided into national zones. Russia changed its position as far as the seabed is concerned when it discovered new reserves off its shores in 1998. Iran insists that the Caspian be divided in equal shares among the five coastal states. The lack of a normative agreement on the legal status of the Caspian Sea, and thus on the division of territorial waters and hydrocarbon resources (as well as on the rules regulating the passage of pipelines along the seabed) presents significant obstacles to the exploitation of the many oil and gas fields that have been discovered beneath the Caspian's waters. This state of affairs has engendered several still-unresolved disputes.

Faced with the impossibility of signing a regional treaty, some littoral states have resorted to a series of bilateral or trilateral agreements. Kazakhstan signed a bilateral agreement with Turkmenistan in 1997 to partition the two countries' shares of the sea. Ashgabat has taken a back seat in the negotiations since then, and keeps its position intentionally unclear. In 2001 and 2003, Azerbaijan aligned itself with Russia and Kazakhstan, and the three countries agreed on the partitioning of the waters. Those agreements, nevertheless, do not specify the status of cross-border deposits (except those between Kazakhstan and Russia). Iran does not recognize the bilateral agreements that have been established between the other littoral states. The southern part of the Caspian basin - where most of the deposits have been discovered - is therefore the most disputed. Azerbaijan, Turkmenistan, and Iran all have zones of bilateral conflict in this region.

Finding a collective solution in order to definitively settle the legal framework of the sea becomes therefore more and more crucial. Three summits gathering the heads 
of the five littoral states have been organized, most recently in Baku in 2010. However, they all failed to resolve the question of the sea's legal status, or even to make any progress on the main issues discussed. ${ }^{2}$ The question at the core of the Caspian dispute resides with the very definition of this body of water: Is it a sea or a lake? On the one hand, Azerbaijan, Kazakhstan, and Turkmenistan insist that it is a sea, and national sectors should therefore be based on a median line. On the other hand, Iran defines it as a lake, and thus asserts that each state should receive a fifth of the whole body of water. Russia, for its part, has proposed that all five states share the waters - and thus the fishing rights - of the Caspian, which would render impossible the building of a pipeline across the sea. According to the Russian proposal, the seabed and the resources underneath would be divided along sectorial lines. Both cases imply substantially different outcomes for all littoral states. The definition of the Caspian directly impacts the delineation of maritime and seabed borders, and therefore the attribution of oil and gas fields to one state or another. Additionally, if the Caspian were defined as a sea, then there would be legal precedents obliging Russia to grant access permits to foreign vessels via the Volga River.

\section{Increasing Tensions}

In the absence of a stable legal framework, territorial disputes between littoral states are inevitable. Despite their unclear status, most of the deposits lying underneath the Caspian are currently being exploited, leading to dangerous military incidents involving Azerbaijan, Iran, and Turkmenistan. In 2000, an Azerbaijani vessel was denied access to oilfields in the southern Caspian by the Iranian Navy. ${ }^{3}$ Similarly, diplomatic cables obtained by Wikileaks and made public in 2011 revealed that Iran moved an oil rig into waters that are disputed between Azerbaijan and Iran in November 2009. Baku's inability to react to these incidents pushed Azerbaijan to continue increasing its military capacity and seeking greater military cooperation with external actors, the United States in particular. ${ }^{4}$

In June 2012, according to Turkmen border services, an Azerbaijani patrol ship took "unlawful actions" against a civilian ship carrying out what Ashgabat described as "scientific research" work in the Kapaz/Serdar oil field, a part of the Caspian disputed by the two countries. ${ }^{5}$ In 2008 , following a similar incident, the two states had reached an agreement that was supposed to halt all exploration in the area until the status of the

2 The only concrete achievement was a resolution adopted in 2008 that authorizes ships flying the flag of one of the five states to circulate in the Caspian.

3 “Azerbaijan's Military Exercises in the Caspian: Who Is the Target?" Eurasia Daily Monitor 9:94, Jamestown Foundation (17 May 2012); available at www.unhcr.org/refworld/ docid/4fbccbd92.html.

4 "Iran, Azerbaijan in Tense Caspian Standoff, Cables Show," Eurasia.net (4 October 2011); available at www.eurasianet.org/node/64268.

5 Keith Weber, "Azerbaijan and Turkmenistan Disputes and the Tragedy of the Commons," Rep's Blog, Center for Strategic and International Studies (15 November 2012); available at http://csis.org/blog/azerbaijan-turkmenistan-disputes-and-tragedy-commons. 
field was agreed upon. ${ }^{6}$ Furthermore, Russia has threatened through semi-official channels to take military action if Azerbaijan and Turkmenistan agree to the construction of a pipeline across the Caspian that would bypass Russian territory. ${ }^{7}$

Instead of fostering the creation of a collective agreement, the rising levels of competition and mistrust are pushing the region towards increasing militarization. These incidents, occurring in parallel to a general military build-up, may escalate into potential large-scale confrontations over the disputed oil and gas fields or the reluctance of some littoral states to agree to the construction of a trans-Caspian pipeline.

\section{Regional Military Escalation}

The legal black hole surrounding the delineation of the Caspian's national maritime borders has contributed to the emergence of tensions between the littoral states over the ownership of oil and gas fields. The Russia-Kazakhstan dispute has been managed diplomatically since $2002,{ }^{8}$ but the relationships between Azerbaijan and Turkmenistan, and Azerbaijan and Iran, remain extremely tense over Baku's signing of contracts with international companies for the exploration and exploitation of disputed oil fields.

As the five littoral countries are arguing over how to divide the basin among themselves, each capital seeks insurance that it can support its territorial pretentions with stronger military power. As a result, the Caspian basin has witnessed a militarization process that has considerably increased in the past years. In the 1990s, the majority of the five coastal countries tried to avoid the militarization of the Caspian Sea. With the fall of the USSR, Moscow proposed to share the former empire's military resources in equal parts among its newly independent republics, but only Azerbaijan accepted the offer. Turkmenistan and Kazakhstan refused, and favored a common fleet under Russian command. The latter was only short-lived, and the two states soon changed their positions as they confronted increasing national security challenges, and did not want to be dependent any longer on Moscow for their defense. In the last few years the postSoviet states have established their own military maritime infrastructure. Those naval build-ups will necessarily raise tensions, and increase the risk of conflicts breaking out in this volatile region.

Russia remains by far the uncontested leader among the Caspian naval powers. The Russian authorities defined the Caspian as a zone of national strategic interest at the beginning of the 2000s, and the Russian Navy's fleet has been steadily developed since then. In May 2011, the commander in chief of the Russian Navy announced that the

6 “Azerbaijan Angered by Turkmenistan's Work on Disputed Caspian Field,” Azernews (20 June 2012); available at www.azernews.az/oil_and_gas/42552.html.

7 Vladimir Socor, "Bluff in Substance, Brutal in Form: Moscow Warns Against Trans-Caspian Project," Eurasia Daily Monitor 8:217, Jamestown Foundation (30 November 2011); available at www.jamestown.org/single/?no_cache $=1 \&$ tx_ttnews\%5Btt_news\%5D=38723.

8 World Briefing "Europe: Russia, Kazakhstan: Caspian Pact," The New York Times (14 May 2002; available at http://www.nytimes.com/2002/05/14/world/world-briefing-europe-russiakazakhstan-caspian-pact.html. 
Caspian fleet would be allocated sixteen new ships by the end of $2020 .^{9}$ With its 148 vessels of multiple dimensions and functions, Russia already has the strongest presence in the Caspian Sea. Russia is strengthening its position in the Caspian to prevent it from falling under the influence of Western powers. Moreover, the Russian authorities have the capacity to create obstacles for other littoral countries that wish to increase their naval power, as it controls the only waterway into the Caspian: the Volga River. Moscow has so far allowed donated or purchased vessels to be shipped through that channel, but it may change its position on the issue at any moment. In order to be able to build its ships and remain independent, Azerbaijan has constructed its own shipyard. ${ }^{10}$ For their part, Kazakhstan has secured the help of South Korea to build its own in the near future, ${ }^{11}$ and Turkmenistan announced in January 2013 its plan to set up a ship repair and construction plant near the port of Turkmenbashi. ${ }^{12}$

Following the Russian example, Iran, which has the second-largest naval force in the region, has been strengthening its fleet. At the beginning of the 1990s, the Iranian Caspian fleet was obsolete, and Teheran had to engage in a large-scale modernization of its naval forces. Teheran announced in 2001 its intention to add another seventy-five missile ships to the fleet, already reportedly made up of sixty to ninety vessels. ${ }^{13}$ Teheran even stated in August 2012 that it will deploy light submarines in the Caspian Sea, ${ }^{14}$ and launched a new domestically built destroyer in March $2013 .{ }^{15}$ Iran's development of its military presence in the Caspian is causing worry in Russia, and is part of the larger general militarization of the basin. Despite the insistence of the two countries on their "strategic relationship," Moscow wants to ensure that it remains able to impose its will on the other littoral states, and therefore does not cast a favorable eye on the emergence of potential military competitors in the region.

Competition and mistrust led to the current situation. Intimidated by their neighbors' military superiority, which was only continuing to increase, Azerbaijan, Kazakhstan, and Turkmenistan felt compelled to react. The littoral countries see their counterparts' naval development as a security threat. Trying to keep up with two mightier military powers Russia and Iran, the three neighbors are now building their

9 "Russia to Strengthen its Caspian Sea Fleet," Russia Today (4 May 2011); available at http://rt.com/politics/caspian-fleet-missiles-warships/.

10 E. Ismayilov, "SOCAR: New Shipyard to Strengthen Azerbaijan's Position in Caspian," Trend.az (25 October 2011); available at http://pda.trend.az/en/1949224.html.

11 "Kazakhstan, South Korea to Mull Building a Shipyard in the Caspian Sea," Interfax.com (4 May 2012); available at www.interfax.com/newsinf.asp?id=329392.

12 "Turkmenistan to Set up Shipyard in Caspian Sea," Aernews.az (18 January 2013); available at www.azernews.az/region/48693.html.

13 Joby Warrick, "Iran Bolsters Retaliation Capability in the Persian Gulf, Experts Say," The Washington Post (26 July 2012); available at http://articles.washingtonpost.com/2012-0726/news/35488801_1_nuclear-facilities-gulf-region-persian-gulf.

14 "Iranian Submarines to Navigate Caspian Sea," Russia Today (30 June 2012); available at http://rt.com/news/submarines-caspian-iran-oil-123/.

15 "Iran Launches Destroyer in Caspian Sea," Radio Free Europe/Radio Liberty (17 March 2013); available at www.rferl.org/content/iran-navy-destroyer-caspian/24931091.html. 


\section{THE QUARTERLY JOURNAL}

own fleets from scratch. In this regard, the regional environment was modified when the United States declared the Caspian Sea vital to its strategic interests in the 2000s. In an attempt to strengthen its partners, Washington launched considerable military cooperation programs directed toward Kazakhstan, ${ }^{16}$ Turkmenistan, ${ }^{17}$ and above all Azerbaijan. $^{18}$

Azerbaijan is indeed becoming increasingly serious about its naval security. Until the demise of the USSR, the Soviet Caspian fleet was based in Baku. Azerbaijan kept the infrastructure left on its territory after it became independent, as well as a share of the Soviet ships. In recent years, the country has received thirty patrol cutters and three motorboats from the United States and Turkey. ${ }^{19}$ The U.S. also helped install maritime radar along the coast of Azerbaijan and establish a command-and-control center in Baku. More recently, Azerbaijan purchased anti-ship missiles from Israel. ${ }^{20}$ The U.S. Department of Defense has conducted several engagement exercises with the Azerbaijani Navy focused on building capacity for critical energy infrastructure protection. The main perceived threat in the Caspian for Azerbaijan remains Iran, but Russia could also become a source of trouble in the future if the negotiations between Azerbaijan and Turkmenistan over a trans-Caspian pipeline bypassing Russian territory were to lead to concrete results.

Following the same trend, Astana is boosting its maritime power. Kazakhstan possesses five ports on the Caspian, but none of them were used for military purposes during Soviet times. The Kazakh authorities have thus had to build a new naval infrastructure from scratch. After Kazakhstan withdrew from the Russia-led common naval protection arrangement in 1994, Nursultan Nazarbaiev affirmed in 2003 his intention to transform his country into a naval power by 2015. In April 2012 Kazakhstan

16 E. Kosolapova, "Kazakh and U.S. Defense Ministries Sign Cooperation Plan for 20132017," Azernews.az (11 December 2012); available at http://en.trend.az/regions/casia/ kazakhstan/2097637.html.

17 "For FY2013, [...] peace and security programs include Foreign Military Financing (FMF), for which the Administration has requested \$685,000; International Military Education and Training (IMET), for which the Administration has requested $\$ 350,000$; reforming law enforcement and combating drug-trafficking and trafficking in persons, for which the Administration has requested $\$ 550,000$; and combating weapons of mass destruction, for which the Administration has requested \$500,000." Jim Nichol, Turkmenistan: Recent Developments and U.S. Interests, CRS Report for Congress (Washington, D.C.: Congressional Research Service, 17 August 2012); available at www.fas.org/sgp/crs/row/97-1055.pdf.

18 Roger McDermott, "Azerbaijan Deepens Military Cooperation with the U.S. and NATO," Eurasia Daily Monitor 6:173 (22 September 2009); available at www.jamestown.org/ single/?no cache $=1 \&$ tx ttnews $\% 5 B$ tt news $\% 5 \mathrm{D}=35520$.

19 Marlène Laruelle and Sébastien Peyrouse, "The Militarization of the Caspian Sea: "Great Games' and 'Small Games' over the Caspian Fleets," China and Eurasia Forum Quarterly 7:2 (2009).

20 “Israel Signs \$1.6 Billion Arms Deal with Azerbaijan, Haaretz (26 February 2012); available at http://www.haaretz.com/news/diplomacy-defense/israel-signs-1-6-billion-arms-deal-withazerbaijan-1.414916. 
launched its first domestically produced missile boat, and it is planning to inaugurate two more ships in the coming months. ${ }^{21}$ There have also been talks about buying three more vessels from South Korea. ${ }^{22}$ Moreover, a new air base in Aqtau, a port city in the western part of Kazakhstan, opened in July 2011.

For its part, Turkmenistan has only had a minimal presence at sea for years. At the beginning of the 2000s, when its relations with Baku worsened, Ashgabat decided to commit to the naval protection of its Caspian interests by reinforcing its fleet. The country reportedly possesses only seven patrol boats, three guard ships with guided missiles (bought from Russia in 2008), two Sobol patrol boats, and two Molniya boats. However, despite Turkmenistan being officially neutral, the country's new naval doctrine states that "the naval forces are given the task of ensuring that the country's interests in the Caspian Sea are protected." ${ }^{23}$ With the help of Turkey and Ukraine, Ashgabat therefore established the country's first naval academy in $2011 .{ }^{24}$ That same year, Turkmenistan acquired two missile corvettes featuring new missile systems, placing those ships among the most heavily armed in the Caspian. In the latest episode of the militarization of the Caspian, Turkmenistan held in September 2012 its first ever naval exercise, officially directed against a nominally terrorist enemy, but the details of the exercise suggest that Ashgabat was drilling for a naval engagement with another country. This exercise recalls both Azerbaijan's May 2012 naval exercises and the Caspian component of the Collective Security Treaty Organization's 2011 exercise featuring Russian and Kazakh navies. In both cases, the scenario practiced involved an attack coming from the southern end of the sea, and carried out by exactly the same sort of aircraft that Iran owns.

In October 2005, the Russian Minister of Foreign Affairs Sergey Lavrov proposed the creation of a joint military force, CASFOR, to respond to transnational threats affecting the Caspian region. ${ }^{25}$ However, Kazakhstan, Turkmenistan, and Azerbaijan have politely turned down the offer until now, as they do not wish to engage in what would be an unequal partnership with Moscow.

As each littoral state is busily flexing its muscles, and no agreement is anywhere close to being reached on the status of the Caspian and the ownership of the resources lying beneath it, the risk of witnessing a further increase in tensions in the region lead-

21 D. Mukhtarov, "Kazakhstan Launches First Homemade Rocket Artillery Ship," Trend.az (25 April 2012); available at http://en.trend.az/regions/casia/kazakhstan/2018846.html.

22 Hossein Aryan, "Caspian Sea States on Course for Naval Arms Race," Radio Free Europe/Radio Liberty (27 July 2011); available at www.rferl.org/content/caspian_states on_course_for_naval_arms_race/24278751.html.

23 Catherine A. Fitzpatrick, "Turkmenistan Beefs up Caspian Presence, Irritating Russia," Eurasia.net (30 October 2011); available at www.eurasianet.org/node/64410.

24 “Turkmenistan Establishes Naval Institute under Ministry of Defense," Turkmenistan.ru (6 June 2010); available at www.turkmenistan.ru/?page_id=3\&lang_id=en\&elem_id= 17125\&type=event\&sort=date_desc.

25 Annie Jafalian, "Vers une militarisation de la mer Caspienne? Le projet de la CASFOR," Fondation pour la Recherche Stratégique (30 October 2005); available at www.frstrategie.org/barreFRS/publications/notes/20051030.pdf. 
ing to the breakout of an open bilateral or multilateral conflict remains high. The stakes are high in terms of energy security for some NATO members in the region, and those nations are therefore pressing the Alliance to contribute as much as possible to the stability of the Caspian. Though the 2010 Strategic Concept gives NATO a greater role in the area of energy security, their demands have not been translated into actions so far.

\section{NATO and the Caspian Region}

Since the 1990s, Western leaders and economists have seen the Caspian Sea as a part of the wider Eurasian energy corridor linking Europe to Central Asian energy supplies. The European Union wants to secure the transportation of Turkmen gas via Azerbaijan to Turkey and on to European consumers through a trans-Caspian pipeline, which could simultaneously help reduce Europe's energy dependency on Russia, foster stabilization of the Caucasian and Central Asian regions, and counterbalance Russia's influence in these areas. To achieve this goal, a settlement of the main disputes will have to be promoted, and confidence built among Caspian states.

European countries are not the only actors that have a keen interest in the legalization of the Caspian Sea's status. The Western companies that were granted contracts to exploit Caspian hydrocarbons wish to see the question of the Caspian's status resolved, since regional stability is essential to the security of their investments. On the other hand, Russia and Iran have an interest in delaying any agreement on the Caspian's legal framework, as they possess large reserves of hydrocarbon resources outside the sea itself and are not dependent on Caspian production. Iran wants to keep exerting influence across the region, and Russia refuses to see its territory bypassed by a pipeline linking Europe and Central Asia that would decrease European dependency on its supply of oil and gas. A the same time, cooperation with Iran, even simply at the level of political discussions, is rendered difficult by the lack of willingness on the side of Teheran, as well as the fact that the country is not a NATO partner and does not have any sort of official framework for discussion agreed on with the Alliance. Even though some members would want NATO's role in the region to be complementary to the EU's position, through the PfP program in particular, the Alliance has struggled to find an entry point to the geopolitics of the region.

NATO has been cooperating within the framework of the Partnership for Peace (PfP) with Azerbaijan, Kazakhstan, Turkmenistan, and Russia since the four Caspian littoral states joined the program in 1994. The purpose of the PfP is to increase stability and strengthen security relationships between NATO and its Partners, as well as among PfP countries themselves. The Alliance cooperates with Azerbaijan and Kazakhstan on defense-related work, defense reform, defense policy and planning, education and training, military-to-military cooperation and exercises, civil emergency planning and disaster-response, and science and environmental issues. The relationship with Turkmenistan has been more limited because of Ashgabat's official policy of neutrality. NATO and Russia mainly cooperate on the fight against terrorism and drug trafficking, and in the field of non-proliferation and arms control. Additionally, Azerbaijan currently contributes ninety-four soldiers to the ISAF mission. Kazakhstan and 
Turkmenistan have been central to the northern distribution network, which has been used to transport non-lethal supplies to ISAF forces in Afghanistan. Russia for its part has allowed NATO to use the airbase in Ulyanovsk as a transit point to relay non-lethal supplies. Even though NATO's activities in the region can help foster cooperative relations among its Partner countries, especially through confidence-building, the options are limited for NATO to play a role in the Caspian region and fully reach the goals the Alliance has set for itself in the 2010 Strategic Concept.

\section{NATO's Limited Options in Facing the Challenge of Energy Security}

Recently, energy security has emerged as an important topic on NATO's agenda. In its transition from a Cold War military alliance to an effective and proactive organization that is able to address emerging security challenges, NATO has increasingly recognized energy security as a growing concern. At the 2008 Bucharest Summit, heads of the NATO member states emphasized their readiness to see NATO contribute to energy security by advancing international and regional cooperation, protecting vital energy infrastructure, and engaging in information sharing. NATO's 2010 Strategic Concept renewed this commitment by emphasizing that NATO would "develop the capacity to contribute to energy security, including protection of critical energy infrastructure and transit areas and lines, cooperation with partners and consultations among Allies on the basis of strategic assessments and contingency planning." ${ }^{26}$ At the Chicago Summit, the leaders of the twenty-eight member nations repeated that "a stable and reliable energy supply, diversification of routes, suppliers, and energy resources, and the interconnectivity of energy networks, remain of critical importance." 27

Since the adoption of the 2010 Strategic Concept, NATO has been able to extend dialogue offers to its Partners in the domain of energy security. NATO indeed encourages dialogue with its Partners on issues of mutual concern in the energy security domain, in particular through the work of the Energy Security Section of its Emerging Security Challenges Division. In this regard, the PfP Program constitutes the best framework for cooperation with the Partners on energy security issues. The discussions that take place in this forum allow each PfP country and NATO itself to better understand the positions and concerns of all actors, and to advance international and regional cooperation in this field. Azerbaijan and Kazakhstan, for example, have hosted various events related to the topic of energy security, including the Euro-Atlantic Council Security Forum held in Astana in June 2009, which focused on Afghanistan and energy security. ${ }^{28}$

26 “Active Engagement, Modern Defence," NATO 2010 Strategic Concept, adopted at the Lisbon Summit; available at http://www.nato.int/nato_static/assets/pdf/pdf_publications/ 20120214_strategic-concept-2010-eng.pdf.

27 NATO Chicago Summit Declaration, 20 May 2012; available at www.nato.int/ cps/en/natolive/official_texts_87593.htm?mode=pressrelease.

28 NATO Press Release, "Security Forum Discusses Key Challenges in Central Asia," 25 June 2009; available at www.nato.int/cps/en/natolive/news_55920.htm?selectedLocale=en. 


\section{THE QUARTERLY JOURNAL}

Through the organization of international and regional workshops, events, and exercises, NATO helped create transnational professional networks. Through their participation in PfP events, Azerbaijani experts have been able to meet and build connections with experts from NATO Headquarters and Allied countries. After a first event organized in 2009, in November 2012 Baku hosted a seminar supported by NATO on the topic, "Ensuring energy security in the future and NATO's role in protection of critical energy infrastructure in the Caspian basin." By bringing together experts to share best practices and experiences, this international cooperative approach adopted by NATO's Energy Security Section indirectly fosters political stability. In the case of the Caspian Sea, in the long term the region is made more attractive to foreign investments, including from NATO countries, especially in the energy field.

In parallel, NATO staff also assists the Alliance's Partners in improving their preparedness and ability to recover, and tracks developments in the technological and environmental realms that can affect energy security. ${ }^{29}$ Moreover, NATO's Science for Peace and Security (SPS) Program organizes workshops that bring policy makers and experts together to discuss Euro-Atlantic energy security and supply.

The dialogue fostered by NATO on energy security issues with its Partners has been a success, as the example of the Caspian region shows. However, for two main reasons the wish to see NATO play a greater role in energy security issues expressed in the 2010 Strategic Concept has not been fulfilled.

The first reason lies in the lack of consensus among the Allies on NATO's role. Even though NATO's European members were collectively affected by the January 2006 Ukraine-Russia gas dispute, the Allies have often adopted individual national policies with regard to threats to energy security. While some countries within the Alliance are pushing for a strong commitment on this issue, others are indeed more reluctant to accept a leading role for NATO. Poland, the Baltic States, and Romania in particular are calling for NATO to play a more prominent role in Europe's energy security.

The second reason is the difficulty of engaging unwilling states. In the Caspian region, NATO has to deal with both Russia and Iran. Dialogue with the latter was nonexistent over the past thirty years until mid-March 2009, when informal talks were held between the two parties. NATO negotiator Martin Erdmann met with the Iranian Ambassador to the European Union, Ali-Asghar Khaji. ${ }^{30}$ For its part, Russia has never taken a favorable view of NATO's involvement-however limited - in the Caspian region. Moscow wants to remain at the center of the Caspian energy game. The Russian leadership seems keen on keeping the Central Asian and Caucasian countries dependent on its network of pipelines, maintaining European dependence on its energy ex-

29 For more information on NATO's approach to emerging security challenges, see Ioanna-Nikoletta Zyga, "Emerging Security Challenges: A Glue for NATO and Partners?" NATO Defense College, Research Paper No. 85 (30 November 2012); available at www.ndc.nato.int/ news/current_news.php?icode $=470$.

30 "Iran and NATO End 30-year Impasse," BBC News (27 March 2009); available at http://news.bbc.co.uk/2/hi/middle_east/7966263.stm. 
ports as a result. Russia looks disapprovingly at the creation of new energy infrastructure projects, and therefore opposes the construction of a trans-Caspian gas pipeline from Turkmenistan to Azerbaijan, ${ }^{31}$ as well as an oil pipeline from Kazakhstan to Azerbaijan, which would be linked with the Baku-Tbilisi-Ceyhan pipeline, bringing Caspian hydrocarbons to the Mediterranean. If built, those pipelines would have a noticeable impact on the hydrocarbon supply networks of the Euro-Atlantic area. They would allow for lower prices in the gas market, a reduced European energy dependency on Russia, and a decrease in Russian influence on the Caspian littoral regions.

In order to dispel misperceptions on the role it aims to play in the area, NATO has reduced its role in the Caspian region to a minimum, and has tried to focus its dialogue efforts on the management of common transnational threats affecting both Russia and NATO. Despite the existence of the NATO-Russia Council (NRC) since 2002, up until now energy-related questions have been rarely, if ever, discussed in the NRC. Russia prefers to address those concerns outside of the multilateral framework, often on a bilateral basis, and prefers to focus instead on hard security issues in its discussions with the Alliance.

\section{Recommendations}

The 2010 NATO Strategic Concept outlines the need for an increased engagement of NATO in dealing with energy security threats, and insists on the inclusion of Partners in addressing this issue. However, the example of the Caspian region shows how difficult the implementation of these principles has been for the Alliance. Despite the emphasis placed in recent years within NATO on addressing emerging security challenges, including energy security, the translation of those words into concrete action has been rather limited so far. Apart from having extended useful (but limited) dialogue offers, NATO has not expanded its role in the field of energy security.

The Caspian region has been studied in this essay as a test case of the limitations faced by the Alliance in the implementation of its energy security policy. The following recommendations could help to define more clearly where NATO could add value:

1. NATO could outline more precisely what role it wishes to play in the Caspian region. Political dialogue should be at the core of NATO's relationship with the Caspian littoral countries. The Alliance's efforts in coordinating with its Partners have to be continued and pushed farther. NATO should function as a forum for regional cooperation by engaging more often and more in-depth with its Partners in the region. Taking into account the absence of any formal multilateral framework for dialogue in the Caspian region, NATO should support its Partners in finding opportunities to discuss issues of common in-

31 After years of political hesitations on the part of Ashgabat, the European Union (EU) was finally able to engage in September 2011 in negotiations with both Azerbaijan and Turkmenistan on the construction of a trans-Caspian natural-gas pipeline. See European Commission Press Release, "EU Starts Negotiations on Caspian Pipeline to Bring Gas to Europe," 12 September 2011; available at http://europa.eu/rapid/press-release_IP-11-1023_en.htm. 
terest. With the PfP countries concerned-Azerbaijan, Kazakhstan, Russia, and Turkmenistan-NATO should hold more frequently $28+1$ and $28+\mathrm{N}$ meetings, at the ambassadorial level or below.

2. NATO should make cooperation with its Partners on energy security a clear priority area for dialogue, discussion, and coordination in its Individual Partnership Programs (IPAPs). Furthermore, in coordination with their Partners, Allies should define and list the means and mechanisms they need to meet the challenges of energy security in the Caspian region and in other geographic areas.

3. In parallel, specific efforts should be made to improve NATO's relationship with Russia. Political dialogue and discussions on regional stability have to be at the center of the partnership with Russia. Taking steps towards confidence building between Moscow and Brussels will be essential if NATO intends to avoid unnecessary tensions and diffuse misunderstandings about its intentions. The recent appointment of a new Russian Ambassador to NATO is to be seen in this context as a positive sign, as it will allow for discussions at the North Atlantic Council in the framework of the NRC to resume after a year of inertia.

4. Partners in the region, such as Azerbaijan and Kazakhstan — and, to a lesser extent, Turkmenistan - welcome NATO's support for the reform of their defense institutions. The Alliance should therefore contribute further to the professionalization and standardization of the Caspian littoral states' military forces and structures. Setting up shared standards can indeed help build confidence among the concerned Partners and avoid misunderstandings.

5. As part of its outreach strategy, NATO and its Emerging Security Challenges Division could increase the number of conferences it holds related to energy security. It could also create new courses addressing the issue and open them to nationals of Partner countries. Additionally, NATO should invest significantly in best-practices exchanges and emergency preparedness trainings regarding the protection of energy infrastructure.

6. NATO will have to recognize that it needs to engage countries, such as Iran, which view the Alliance as a negative factor in their own security equation. As the example of the Caspian region has shown, NATO's outreach and preventive work can only be effective if the Alliance listens to and takes into account the point of view of these actors.

7. NATO should cooperate more closely with the OSCE and the EU in both formal and informal formats on energy security. In order to avoid duplication in their regional programs, international organizations should design a common working plan, clearly defining the role of each organization in this domain. 


\title{
Ballistic Missile Defense in Poland: Did the Costs Outweigh the Benefits?
}

\author{
Colonel Steven D. Dubriske*
}

\section{Introduction}

The government of Poland has addressed a number of difficult national security issues since the nation regained its independence from Soviet control in 1989. Longstanding border disputes with neighboring countries and the perceived disparate treatment of Polish minorities in these countries are just two examples of the many external security challenges Poland faced head-on after its emergence from the Warsaw Pact. Poland's leadership has also addressed a number of internal security problems, such as the modernization of its Cold War-era military and the transfer of control of the armed forces from the Polish General Staff to civilian authorities within its Ministry of Defense.

Notwithstanding these daunting security challenges, Poland's decision to support elements of a U.S. ballistic missile defense (BMD) program on its sovereign soil has arguably posed the most complex national security dilemma for Polish leaders in this most recent chapter of its long national history. This essay will examine the decision to support the BMD program from the perspective of the Polish government, focusing in particular on the BMD program proposed and eventually implemented by the Obama Administration in 2009. After providing a historical summary of the United States' BMD program as it applies to Poland, the article will examine the domestic context within Poland, and how this context influenced the actions of government officials charged with evaluating the BMD program.

The essay will then review Poland's national interests in accepting a BMD program on its soil, and will discuss how Polish officials negotiated with the Obama Administration to gain concessions in support of these national interests. Finally, the essay will examine how the decision to support the BMD program affected Poland's long-term relationships with neighboring countries within the European Union (EU) and, most importantly, Russia. By allying with the United States and, to a certain extent, the North Atlantic Treaty Organization (NATO) on BMD, Poland put itself in the middle of a highly contentious international dispute. Given the security guarantees, military modernization, and potential economic aid that resulted from this eventual support, however, the decision by the Polish government will likely prove to be a beneficial one, as Poland continues to rapidly emerge from the shadows of the Warsaw Pact.

\footnotetext{
Colonel Dubriske is a United States Air Force officer currently serving as the Staff Judge Advocate, Headquarters Eighth Air Force (Air Forces Strategic), Barksdale Air Force Base, Louisiana. This essay was initially submitted in March 2012 as a course requirement at National War College where Colonel Dubriske was assigned as a student. The views expressed in this article are those of the author and do not reflect the official policy or position of the National Defense University, the U.S. Department of Defense, or the United States Government.
} 


\section{The Roots of the BMD Program in Poland}

Following several years of discussions with the Polish government, President George W. Bush proposed a European BMD program in early 2007. The program, similar to installations in Alaska and California that focus on ballistic missile threats from North Korea, called for the deployment of ten silo-based interceptor missiles in Poland to target ballistic missile attacks originating from Iran. ${ }^{1}$ The system, it was believed, would optimize ballistic missile defensive coverage for the United States, as well protect U.S. allies and U.S. personnel stationed in Europe. ${ }^{2}$

The Polish government, then under the leadership of President Lech Kaczynski and Prime Minister Jaroslaw Kaczynski, was eager to implement the BMD program without any U.S. concessions. The twin brothers believed the mere presence of U.S. troops on Polish soil not only markedly increased the country's defenses against foreign aggression, but also improved its relationship with what they saw as an important future ally in the United States. ${ }^{3}$ Because of these benefits, President Kaczynski and Prime Minister Kaczynski did not connect their support of the agreement to U.S. concessions on foreign aid or foreign military sales. ${ }^{4}$

In October 2007, parliamentary elections split control of the Polish government, which resulted in the replacement of Jaroslaw Kaczynski as prime minister. The new prime minister, Donald Tusk, was more cautious on the proposed BMD project, and he made it clear that his government would carefully weigh the costs and benefits of the BMD program and bargain more actively on behalf of Poland's national interests. ${ }^{5} \mathrm{Al}-$ though there were multiple discussions throughout the first half of 2008 between the United States and Poland, an agreement on the terms of the BMD program could not be reached.

Then, in early August 2008, Russian forces engaged in armed conflict with Georgia over a separatist movement in South Ossetia. Within a week of the start of this conflict, the Polish government agreed in principle to support the proposed BMD program. Under the agreement, Poland received enhanced security guarantees from the United States and a pledge to help modernize Poland's air defense system. ${ }^{6}$ The surprise decision by the Polish government to support the BMD program may have also been pushed along by U.S. discussions with Lithuania on alternative BMD basing arrangements if the agreement with Poland could not be secured in a timely manner. ${ }^{7}$

Given that over one-half of the public in Poland opposed the government's support of the BMD program, the ratification of the agreement by the Polish government was

1 Steven A. Hildreth and Carl Ek, Long-Range Ballistic Missile Defense in Europe (Washington, D.C.: U.S. Congressional Research Service, report RL34051, 23 September 2009), 1. Ibid., 6.

Kejda Gjermani, “The Missile-Defense Betrayal,” Commentary (December 2009): 24. Ibid.

Hildreth and Ek, Long-Range Ballistic Missile Defense in Europe, 10.

Ibid., 11.

Wade Boese, "U.S. Presses Poland on Anti-Missile Site," Arms Control Today 38 (July/ August 2008): 54. 
delayed as the program was subjected to public debate. ${ }^{8}$ A major subject of debate was whether the agreement, if ratified by the Polish government, would be honored by the new U.S. presidential administration after the elections of November 2008. The Poles were mainly concerned about expending political capital and alienating the Russian government only to have a new U.S. administration reject the BMD program outright. ${ }^{9}$

\section{The Obama Administration and the BMD Agreement with Poland}

Before the Polish legislature could ratify the BMD agreement, President Barack Obama was inaugurated, and honored his campaign pledge to review the European BMD program. On 17 September 2009, President Obama cancelled the previous agreement with Poland and its other partners for silo-based interceptors. ${ }^{10}$ Instead, President Obama announced the United States would adopt a new BMD program, commonly referred to as the European Phased Adaptive Approach (EPAA) program, which would deploy both sea- and land-based ballistic missile interceptors. ${ }^{11}$ Although there were initial concerns within the Polish government that Poland would not be part of the EPAA program, the Polish government agreed on 3 July 2010 to accept the deployment of land-based interceptors by $2018 .^{12}$

Given the domestic context in Poland, the securing of an agreement with the United States on the EPAA program was a significant accomplishment for the Polish government. As previously discussed above, the BMD program was never popular with the Polish public. In fact, 56 percent of the Polish population in one poll agreed with President Obama's decision to cancel the Bush-era BMD program. ${ }^{13}$ Many Poles holding this opinion felt the BMD program was purely an "American project," as Poland faced little threat from Iran. ${ }^{14}$ Comparing this minimal threat against the more realistic threat posed by a Russian government fearing NATO encirclement, the majority of the Polish population needed significant convincing from its government to support any BMD program on Polish soil. ${ }^{15}$

Previous supporters of the Bush-era BMD program also had to be swayed by the Polish government. Many supporters felt betrayed by the Obama Administration's de-

8 Gjermani, "The Missile-Defense Betrayal," 24; Hildreth and Ek, Long-Range Ballistic Missile Defense in Europe, 9.

9 Gjermani, "The Missile-Defense Betrayal," 24-25.

10 President Barack Obama, "Remarks by the President on Strengthening Missile Defense in Europe," Office of the White House, 17 September 2009; available at www.whitehouse.gov/ the_press_office/Remarks-by-the-President-on-Strengthening-Missile-Defense-in-Europe.

11 Department of State Fact Sheet, "United States European Phased Adaptive Approach (EPAA) and NATO Missile Defense," Bureau of Arms Control, Verification and Compliance, 3 May 2011.

12 Ibid.

13 Marek Madej, “Obama's Missile Defense Rethink: The Polish Reaction," The Bulletin of the Atomic Scientists (30 September 2009): 2.

14 Gjermani, "The Missile-Defense Betrayal," 24.

15 Hildreth and Ek, Long-Range Ballistic Missile Defense in Europe, 11. 
cision to cancel the initial BMD program. These supporters felt that Poland had expended significant political capital in supporting the program at home, as well as put itself in an uncomfortable position with respect to Russia, only to have the Obama Administration appease Russian objections by canceling the program. ${ }^{16}$ Additionally, many Poles felt the United States did not appreciate the contributions of Polish military forces in Iraq and Afghanistan, and that the decision to cancel the BMD program was further proof of this ingratitude. ${ }^{17}$

Because the government was subject to criticism by both supporters of the previous BMD program and opponents of any BMD program, Polish politicians had to convince the public that the revised program was in Poland's national interest. To do this, the politicians focused primarily on the security and economic benefits of the agreement with the United States. From an economic perspective, politicians noted that Poland was near the top of European countries receiving U.S. military assistance, obtaining over USD 750 million in aid since $2001 .^{18}$

Arguments for the security benefits of the BMD program were made more difficult by the fact that Poland was already a member of NATO and, therefore, possessed the Article V collective defense guarantee. Polish officials, however, argued that the bilateral agreement with the United States, entitled the "Declaration on Strategic Cooperation," provided additional protection as it had the backing of NATO's primary benefactor: the United States. ${ }^{19}$ Additionally, the temporary stationing of U.S. air defense personnel in Poland pursuant to the bilateral agreement made it unlikely that Poland's sovereignty would be violated by a neighbor out of fear of a U.S. response. This fact was recognized by a former Polish foreign minister, who publicly stated "[E]veryone agrees that countries that have U.S. soldiers on their territory do not get invaded." 20

The Polish government wisely used the threat of outside attack to drive home the security benefits of the BMD agreement with the United States. By pointing towards Russian aggression against Georgia, Polish politicians could underscore the credibility of the threat and the need for security assurances provided by the BMD agreement. ${ }^{21}$ The Polish government could also highlight not only the constant Russian rhetoric about the negative impact of the BMD program on European stability, but also Russia's threat to move mid-range nuclear missiles near the Polish border with Kalini$\operatorname{grad}^{22}$ By focusing the discussion of the benefits of the BMD program on a realistic threat, given Poland's history with Russia, Polish politicians received sufficient domestic support to pursue a BMD agreement with the United States.

16 Ibid., 2.

17 Madej, "Obama's Missile Defense Rethink," 3.

18 Karen DeYoung, "U.S., Poland Closer to Deal on Missile Defense," The Washington Post (2 February 2008): A16.

19 Hildreth and Ek, Long-Range Ballistic Missile Defense in Europe, 11.

20 Ibid., 12; Gjermani, "The Missile-Defense Betrayal," 24.

21 Gjermani, "The Missile-Defense Betrayal," 25.

22 Hildreth and Ek, Long-Range Ballistic Missile Defense in Europe, 11. 


\section{Revising the BMD Agreement}

With a minimum level of domestic support in hand, the Polish government turned toward its negotiations with the United States. While the government headed by the Kaczynski brothers only appeared to be concerned with strengthening Poland's security through the BMD program, the government of Prime Minister Tusk focused on two additional Polish national interests: military modernization and continued U.S. economic support. ${ }^{23}$ With these national interests in the forefront, Prime Minister Tusk sought to obtain additional concessions, such as the deployment of U.S. air defense batteries on Polish soil and over USD 20 billion in U.S. aid to modernize elements of the Polish military. ${ }^{24}$ While Prime Minister Tusk was unable to secure significant financial aid for modernization, the Polish government did obtain the air defense batteries, a pledge from the United States to assist Poland in the modernization of its forces, and an industrial agreement to boost Poland's defense industries through cooperative technology research and development. ${ }^{25}$

The success of the Polish negotiations with the United States can be attributed to a number of factors. Most importantly, the Polish government did not publicly overreact or criticize the United States after President Obama's decision to cancel the Bush-era BMD program. ${ }^{26}$ Some commentators in Poland lambasted the United States and labeled the decision as a "betrayal." ${ }^{27}$ Given the lack of domestic support for the BMD program, it would have been easy for the Polish government to follow suit and publicly criticize this shift in U.S. policy. Seeing the larger picture, however, Prime Minister Tusk and his government downplayed the decision and continued to voice support for a strong U.S.-Poland partnership. ${ }^{28}$ This positive approach, it could be argued, not only benefited Poland with regard to the BMD program, but also contributed to the decision by the United States to establish an aviation detachment in Poland in support of periodic deployments of U.S. aircraft to Poland on a rotational basis. ${ }^{29}$

The Tusk government also made use of the domestic unpopularity of the BMD deployment, and concerns over Russia's response, to negotiate more tangible security benefits in the form of air defense batteries. ${ }^{30}$ With regard to the Russian threat, Prime

23 Gjermani, "The Missile-Defense Betrayal," 24.

24 Ibid., 24.

25 Andrew Somerville, Ian Kearns, and Malcolm Chalmers, Poland, NATO and Non-Strategic Nuclear Weapons in Europe, Royal United Services Institute Occasional Paper (London, February 2012), 8; available at www.rusi.org/downloads/assets/Poland-NATO-and-NSNW120217.pdf.

26 It appears that the Polish government has taken a similar public position in response to the non-reassuring comments from President Obama to President Medvedev that were inadvertently recorded during a meeting in South Korea on 26 March 2012. Hildreth and Ek, Long-Range Ballistic Missile Defense in Europe, 2.

28 Ibid., 2 and 12; Madej, "Obama's Missile Defense Rethink," 2.

29 Somerville, Kearns, and Chalmers, Poland, NATO and Non-Strategic Nuclear Weapons in Europe, 8.

30 Ibid., 7. 
Minister Tusk argued that the United States should help improve Poland's air defenses to counter increasingly threatening behavior from Russia due to Poland's support of BMD. ${ }^{31}$ Russia clearly stated in public comments that Poland would be targeted if it participated in the BMD program as proposed by the United States. Thus, the Polish government believed it was reasonable for the United States to bear some of the financial cost for this added protection. While the United States and Poland attempted to downplay the appearance of a quid pro quo relationship between BMD and air defenses, a number of public statements by both U.S. and Polish governmental officials gave the appearance that air defense assistance was directly linked to the increased threat from Russia. ${ }^{32}$

\section{The European Response}

Poland's pursuit of its national interests with regard to the BMD program was not accomplished in a vacuum. As such, its negotiated agreement with the United States impacted its relationships with its European Union neighbors and Russia to varying degrees. Public opinion within Europe was overwhelmingly opposed to BMD deployment as proposed by the United States. ${ }^{33}$ Many critics argued that the BMD system was just another sign of U.S. unilateralism, which had the potential to make Europe less safe due to the alienation of Russia over the program. ${ }^{34}$ Additionally, some opponents believed Europe would not be a target of Iran if European countries rejected the U.S. plan for BMD on the continent.

Given this criticism, there were real concerns that Polish participation in the EPAA program could damage its relationship with fellow members of the European Union. ${ }^{35}$ However, Poland appears to have lost little political capital with its EU neighbors from its participation in the program. While there was some concern that Poland's actions potentially harmed overall European security because of its impact on Russia, most public criticism of the EPAA program was primarily focused on the United States and its lack of consultation with other European leaders regarding its BMD plans. ${ }^{36}$ Additionally, many EU leaders were actually supportive of the general concept of BMD and its potential to protect Europe from rogue states in the Middle East. ${ }^{37}$ Because of this inherent political support, Poland's participation in the U.S.-led program received limited criticism from EU leaders. Finally, the eventual decision by NATO to pursue

31 Boese, "U.S. Presses Poland on Anti-Missile Site," 1.

32 James Gerstenzang and Peter Spiegel, "Bush Links U.S. Aid to Poland with Missile Defense System," The Los Angeles Times (11 March 2008): A3.

33 Representative Ellen Tauscher, "European Missile Defense: A Congressional Perspective," Arms Control Today 37 (October 2007): 12.

34 Camille Grand, "Missile Defense: The View from the Other Side of the Atlantic," Arms Control Today 30 (September 2000): 12; Hildreth and Ek, Long-Range Ballistic Missile Defense in Europe, 16.

35 Hildreth and Ek, Long-Range Ballistic Missile Defense in Europe, 16.

36 Ibid., 22.

37 Ibid., 17. 
BMD capabilities for the entire alliance quickly mitigated concerns that Poland had placed its own security interests over those of other EU members.

The same cannot be said, however, for Poland's relationship with Russia. Although its negative foreign policy campaign against BMD has primarily been focused against the United States and NATO, Russia's threats of retaliatory measures have also been targeted against Poland and other European countries supporting the U.S. and NATO BMD programs. Russia believes the burgeoning BMD programs are nothing more than a precursor to more ambitious offensive programs targeted at Russia. ${ }^{38}$ Because of this perceived threat, Russian political and military leaders have both publicly stated that Poland's acceptance of BMD capabilities make it a potential target for nuclear attack by Russian forces. ${ }^{39}$

Obviously, the constant Russian rhetoric on this issue has strained diplomatic relations between Poland and Russia. While the United States has taken the lead in mitigating Russian complaints by explaining the technical limitations of the BMD program, Poland has also taken some actions to assuage Russian concerns. For example, Polish leaders made a public declaration that they would allow Russian authorities to inspect all BMD equipment on Polish soil to confirm the limited, defensive nature of the system. ${ }^{40}$ Given the strong Russian position on the threat posed by BMD, however, it is unlikely that any words or actions by the Polish government will adequately address Russian concerns. In this light, the Polish government will have to look to other areas of cooperation such as free trade and energy development to strengthen its relationship with Russia.

\section{Conclusion}

Unfortunately, in view of the fact that the BMD system will not be operational until 2018 , there is much that could change in the future with regard to the EPAA program. Increased Russian aggression and the potential for another reversal in U.S. policy could quickly change Poland's perspective on the benefits of accepting elements of the BMD program on its territory. At this point, however, it is clear that the government of Poland benefited significantly from its agreement with the United States on ballistic missile defense. The Poles improved their already solid relationship with the United States, one of the few countries Poland has historically trusted to come to its aid. Additionally, the Polish government obtained increased security guarantees against exter-

38 Ibid., 19.

39 Ibid., 21.

${ }^{40}$ Gordon Fairclough, "U.S., Poland Amend Missile-Defense Plan," Wall Street Journal (3 July 2010). 


\section{THE QUARTERLY JOURNAL}

nal threats, and also improved the capabilities of its own military forces. While the negative impact on its relations with Russia is regrettable, Poland is arguably a stronger country, partner, and ally than it was before it decided to support a ballistic missile defense program on its sovereign soil. 


\title{
GAO Report on Security Force Assistance
}

\author{
More Detailed Planning and Improved Access to Information Needed to \\ Guide Efforts of Advisor Teams in Afghanistan
}

\section{Highlights}

\section{Why GAO Did This Study}

ISAF's mission in Afghanistan has shifted from a combat role to focus more on preparing ANSF units to assume lead security responsibility by the end of 2014. A key element in advising and assisting the ANSF is SFA advisor teams, provided by the U.S. Army and Marine Corps. A House Armed Services Committee report accompanying its version of the Fiscal Year 2013 National Defense Authorization Act directed GAO to review DOD's establishment and use of SFA advisor teams. Specifically, GAO evaluated the extent to which (1) DOD, in conjunction with ISAF, has defined SFA advisor team missions, goals, and objectives; (2) the Army and Marine Corps have been able to provide teams; and (3) the Army and Marine Corps have developed programs to train teams for their specific missions. GAO reviewed doctrine and guidance, analyzed advisor requirements, reviewed training curricula, and interviewed Army, Marine Corps, theater command, and SFA advisor team officials in the U.S. and Afghanistan.

\section{What GAO Recommends}

GAO recommends that theater commanders take steps to work with brigade commanders and advisor teams to identify end states, objectives, and milestones for the development of their ANSF counterpart units in support of the regional commands' broad goals, and that the Army and Marine Corps improve availability of missionspecific information prior to advisor teams' deployment. DOD partially concurred with GAO's recommendations and identified actions to further prepare SFA advisor teams for their missions.

\section{Abbreviations}

ANSF

CENTRIXS-I

COMISAF

DOD

ISAF

SFA
Afghan National Security Forces

Combined Enterprise Regional Information Exchange System-ISAF

Commander, International Security Assistance Force

Department of Defense

International Security Assistance Force

Security Force Assistance

The report under the title "Security Force Assistance: More Detailed Planning and Improved Access to Information Needed to Guide Efforts of Advisor Teams in Afghanistan" (GAO-13381) was presented to the relevant committees in the U.S. Congress by the United States Government Accountability Office in April 2013. The full text of the original report is available at www.gao.gov/products/GAO-13-381. 


\section{Main Findings}

DOD and the International Security Assistance Force (ISAF) have defined the mission and broad goals for Security Force Assistance (SFA) advisor teams; however, teams varied in the extent to which their approaches for developing their Afghan National Security Force (ANSF) units identified activities based on specific objectives or end states that were clearly linked with established goals. SFA guidance states that to be successful, advisors must have an end or goal in mind, and establish objectives that support higher-command plans. Theater commanders have outlined goals aimed at strengthening specific capabilities such as logistics, and it is largely left to the teams to then develop their approach for working with their counterparts. GAO found some advisor teams had developed structured advising approaches drawing from these goals, such as identifying monthly objectives and milestones for their team. Other teams GAO met with used less structured approaches, such as relying on interactions with ANSF counterparts to identify priorities and using this input to develop activities on an ad hoc basis, rather than as part of a longer-term, more structured approach to achieve broad goals. Officials from several teams stated that the guidance they received lacked specificity regarding desired end states for the development of their ANSF counterpart units. Without a more structured approach with clear linkages between end states, objectives, and milestones that are in support of broad goals for ANSF units, theater commanders cannot be assured that the advisor team activities are making progress toward these goals.

The Army and Marine Corps have been able to fill requests for SFA advisor teams, using various approaches such as tasking non-deployed brigades to form advisor teams or creating teams using personnel already deployed in Afghanistan. According to Army and Marine Corps officials, the ability to substitute an individual at one rank above or below the request has helped the services meet rank and skill requirements. The Army's reliance on brigades to provide a portion of their personnel to form advisor teams has enabled them to meet requirements but resulted in leaving large numbers of personnel at the brigades' home stations. To manage these large rear detachments, brigades undertook significant planning to ensure that enough stay-behind leadership existed to maintain a sufficient command structure and provide certain training.

The Army and Marine Corps have developed training programs for SFA advisor teams, but teams varied in the extent to which they had specific information to help prepare them for their mission prior to deployment. SFA guidance states that an indepth understanding of the operational environment and of foreign security force capabilities is critical to planning and conducting effective SFA. Advisor teams may access such information from a variety of sources such as conducting video teleconferences with the teams they will replace, using secure networks to gather information, or sending personnel on predeployment site surveys, although teams varied in the extent to which they were actually able to gain access to these sources. For example, GAO found that while teams had access to a certain secure network at training sites, only some had access at home station, enabling them to shape their training and mission analysis earlier in predeployment training or after training but prior to deploying. 
Having limited access to this information prior to arriving in Afghanistan may result in advisor teams needing more time after deploying to maximize their impact as advisors.

\section{Letter to Committees' Chairs and Ranking Members}

In November 2010, the Afghan government and North Atlantic Treaty Organization (NATO) agreed upon a plan for transferring lead security responsibilities from the NATO-led International Security Assistance Force (ISAF) to the Afghan National Security Forces (ANSF) by the end of 2014 while drawing down international forces. As part of this transition the focus of NATO's mission in Afghanistan is shifting from a combat role to a security force assistance (SFA) role more focused on advising and assisting the ANSF. For the U.S. contribution, the Department of Defense (DOD) has used a variety of approaches to provide U.S. forces to carry out the advise-and-assist mission. For example, in early 2012, the U.S. Army and Marine Corps began to deploy small teams of advisors with specialized capabilities - referred to as SFA advisor teams - that are located throughout Afghanistan to work with Afghan army and police units. Our past work has identified challenges DOD has faced in supporting the advising mission, such as providing and training advisor personnel, balancing advising activities with other missions, and defining command relationships. ${ }^{1}$

The House Armed Services Committee report accompanying its version of the Fiscal Year 2013 National Defense Authorization Act directed us to report on DOD's establishment of SFA advisor teams and the use of these teams to further develop the capabilities of the ANSF. ${ }^{2}$ To address this requirement, this report evaluates the extent to which (1) DOD, in conjunction with ISAF, has defined SFA advisor team missions, goals, and objectives, (2) the Army and Marine Corps have been able to provide SFA advisor teams, and (3) the Army and Marine Corps have developed programs to train SFA advisor teams for their specific missions in Afghanistan.

To address these objectives, we reviewed doctrine, guidance, and key planning documents from NATO, the Army, Marine Corps, and ISAF and U.S. theater commanders pertaining to SFA advisor team missions, goals and objectives, as well as staffing and training of the teams. This documentation included the Army's Field Manual for Security Force Assistance, ${ }^{3}$ the ISAF SFA Concept and Implementation Guidance, requests for forces, ISAF minimum training requirements, and lessons learned from SFA advisor teams. Additionally, we met with officials from relevant organizations in the United States, such as the Office of the Secretary of Defense, Department of the Army, Headquarters Marine Corps, U.S. Central Command, Army Forces Command, and Army and Marine Corps training organizations, as well as officials

GAO, Iraq and Afghanistan: Actions Needed to Enhance the Ability of Army Brigades to Support the Advising Mission (Washington, D.C.: GAO, August 2011), Available at www.gao.gov/products/GAO-11-760.

2 H.R. Rep. No-112-479, at 263-264 (2012) accompanying H.R. 4310. H.R. 4310 became Public Law No. 112-239.

3 Department of the Army, Army Field Manual 3-07.1, Security Force Assistance (May 2009). 
from organizations in Afghanistan, including U.S. Forces-Afghanistan, ISAF, division and brigade headquarters, and 23 SFA advisor teams. Although many ISAF coalition countries deploy SFA advisor teams, the scope of this review included only U.S. SFA advisor teams.

We conducted this performance audit from June 2012 to April 2013 in accordance with generally accepted government auditing standards. Those standards require that we plan and perform the audit to obtain sufficient, appropriate evidence to provide a reasonable basis for our findings and conclusions based on our audit objectives. We believe that the evidence obtained provides a reasonable basis for our findings and conclusions based on our audit objectives. Appendix I contains additional information about our scope and methodology.

\section{Background}

Since 2001, the United States and its NATO partners have been responsible for securing Afghanistan and leading the effort to secure, stabilize, and rebuild Afghanistan. In 2010, the United States, NATO, and other coalition partners agreed to transition lead security responsibility for Afghanistan from NATO to the Afghan government by the end of 2014. Specifically, the Afghan government and ISAF-including the United States-agreed to a transition process that emphasizes a shift in ISAF's role from leading combat missions to advising and assisting the ANSF, resulting in ISAF shifting to a security force assistance mission. ${ }^{4}$ Lead security responsibility in Afghanistan is defined as responsibility and accountability for planning and conducting operations within a designated area, with ISAF support as required. At the same time, overall U.S. force levels are planned to draw down over the next year to about 34,000 with additional decisions on drawdown of remaining U.S. forces yet to be determined.

ISAF is a NATO-led mission in Afghanistan established by the United Nations Security Council in December 2001. The ISAF coalition currently consists of 28 NATO nations, including the United States, and 22 partnering nations with forces deployed across Afghanistan. ISAF is divided into six regional commands across Afghanistan, each with a specific geographic area of responsibility-North, East, South, Southwest, West, and the Kabul area (known as Regional Command-Capital). The United States leads three of these commands-East, South, and Southwest.

In addition to conducting security operations, ISAF forces have long been training and advising the ANSF both in training centers and at unit locations after they have been formed and fielded. For the U.S. contribution, DOD has used a variety of approaches to provide U.S. forces to carry out the advise-and-assist mission. For example, prior to 2010, the advising mission in Afghanistan was primarily conducted with transition teams. These teams did not exist as units in any of the services' force struc-

4 Army doctrine defines SFA as the unified action to generate, employ and sustain local, host nation or regional security forces in support of a legitimate authority. According to NATO, in Afghanistan SFA encompasses all ISAF actions to develop ANSF operational effectiveness and includes partnering and advising, as well as provision of support to ANSF units. 
tures and were instead comprised of company- and field-grade officers and senior noncommissioned officers who were centrally identified and individually selected based on rank and specialty. ${ }^{5}$ As we have previously reported, the demand for these leaders created challenges for the services because, among other things, the leaders were generally pulled from other units or commands, which then were left to perform their missions while understaffed. ${ }^{6}$ In part as a means of alleviating these challenges, the Army developed the concept of augmenting brigade combat teams with specialized personnel to execute the advising mission, and began deploying these augmented brigades in 2010. In early 2012, based on requests from ISAF as part of its shift to a security force assistance mission, the U.S. Army and Marine Corps began to deploy small teams of advisors with specialized capabilities, referred to as SFA advisor teams, which are located throughout Afghanistan, to work with Afghan army and police units from the headquarters to the battalion level, and advise them in areas such as command and control, intelligence, and logistics. ${ }^{7}$ More recently, the Army began tailoring the composition and mission of its brigade combat teams to further focus on advising efforts.

U.S. advisor teams are under the command and control of U.S. commanders within ISAF's regional commands. ${ }^{8}$ The regional commands have overall responsibility for operations in their geographic area, including setting goals for the advising mission. ISAF establishes the requirements for advisor teams, including force needs, and training requirements. To meet the U.S. share of these requirements, the Army and Marine Corps are responsible for providing advisor personnel, establishing service-specific training requirements, and conducting training prior to deployment.

\section{SFA Advisor Team Mission and Goals Are Broadly Defined; Advisor Teams Varied in the Extent to Which Their Approaches Identified Specific Objectives and Activities Linked to Goals}

DOD and ISAF have defined the mission and broad goals for advisor teams based on the type of ANSF (e.g., army, police) and the type of unit, from the headquarters to the

5 Company-grade officers are those in the pay grades of O-1 to O-3 (e.g., lieutenants and captains) and field-grade officers are those in pay grades O-4 to O-6 (e.g., majors, lieutenant colonels, colonels). Senior non-commissioned officers are those in the pay grades of E7 to E9 (e.g., sergeants first class, first sergeants, sergeants major).

6 GAO-11-760, available at www.gao.gov/products/GAO-11-760 and GAO, Iraq and Afghanistan: Availability of Forces, Equipment, and Infrastructure Should Be Considered in Developing U.S. Strategy and Plans, GAO-09-380T (Washington, D.C.: GAO, February 2009), available at www.gao.gov/products/GAO-09-380T.

7 The U.S. Army and Marine Corps have provided the majority of U.S. advisor personnel to Afghanistan, and the Navy and Air Force also have contributed personnel to advise the ANSF.

8 There are some limited instances where U.S. advisor teams may be operating in regional commands that are not led by the United States, though these teams remain under U.S. command. 


\section{THE QUARTERLY JOURNAL}

battalion level. Advisor teams varied in the extent to which their approaches for developing their ANSF counterparts identified activities based on specific end states, objectives, and milestones that are in support of the regional command's broad goals.

\section{DOD and ISAF Have Defined the Mission and Broad Goals for Advisor} Teams for Various Types of ANSF Units

The mission for advisor teams for various types of ANSF units are defined in multiple ISAF and DOD plans, directives, and orders. According to DOD documentation, SFA advisor teams provide training, advising, assisting, and development functions to prepare ANSF units to assume full security responsibility by December 31, 2014. Missions also have been defined for SFA advisor teams based on the type of ANSF unit they advise, specifically:

- Afghan National Army advisor teams are expected to advise and assist those units, act as liaisons to ISAF units, and support the operational planning and employment of the Afghan unit as part of helping to develop a self-sufficient, competent, and professional unit capable of autonomous operations.

- Afghan National Police advisor teams are expected to advise those units, act as liaisons to ISAF units, and support the operational planning and employment of the Afghan unit as part of helping to develop a self-sufficient, competent and professional unit capable of maintaining public order, security, and rule of law.

- Operational Coordination Center advisor teams are expected to advise those units, act as liaisons to ISAF units and support the development of a coherent security coordination structure. ${ }^{9}$

The regional commands have amplified this guidance for advisor teams by providing key advising goals based on the developmental needs of the ANSF in their region. For example, Regional Command-South identified their top-five advising goals, aimed at strengthening ANSF capabilities such as logistics, countering improvised explosive devices, and medical evacuation. Regional Command-East had a similar set of top-five advising goals.

\section{Advisor Teams Varied in the Extent to Which Their Approaches Identified Activities Based on Specific Objectives Linked to ANSF Development Goals}

While ISAF and the regional commands have defined the mission and broad goals for the advisor teams, it is largely left to the teams, in coordination with the regional command and brigade commander for their area of operations, to develop their approach for working with their ANSF counterpart units. According to multi-service guidance on advising, in order to successfully exert influence, advisors have an end or goal in

9 Operational Coordination Centers are ANSF command-and-control organizations that coordinate security operations and civil response to developing situations in their respective areas of responsibility. 
mind. ${ }^{10}$ Similarly, the Army's Field Manual for Security Force Assistance states that, in order to be successful, advisors have an end or goal in mind and should establish objectives and milestones that support higher-command plans and can be achieved during their deployment. ${ }^{11}$ In addition, advisor teams must balance the priorities of their commands with those of their counterpart units. Specifically, DOD officials emphasized that advisor teams need some flexibility to tailor their approaches to the respective needs of their ANSF counterpart units while still working towards regional command goals. Advisor teams we spoke with were generally familiar with the broad goals established by ISAF and regional commands, but used various approaches to develop their ANSF counterpart units, which varied in the extent to which they resulted in the identification of activities based on specific objectives or end states that were clearly linked with established goals.

Some teams we spoke with had taken the initiative to develop structured approaches that identified objectives or end states and milestones, drawing from the regional command's broader goals to guide their advising efforts. For example, one team stated they worked directly from the regional commander's top-five goals, developing a planning process to identify monthly objectives and milestones for each advising area (e.g., personnel, intelligence, logistics) that support these goals, and then regularly assessing where they are in terms of progress towards the commander's goals and in what areas they should continue to focus. Using this process, the advisor team identified a training need for an ANSF brigade related to the regional commander's broad goal of developing the ANSF's counter improvised explosive device capabilities and arranged for a U.S. Explosive Ordinance Disposal unit to provide this training. In another instance, a logistics advisor team identified a need for its ANSF counterpart to be capable of repairing items such as cranes and fuel distribution equipment to help achieve the regional command's broad goal of developing general level maintenance capability. To achieve this objective, the team created a training program to develop this capability. Another team leader we spoke with stated he developed advising plans based on the regional command's high level goals and informed by an assessment of their ANSF counterpart unit, to identify tasks and timelines to train their counterparts on basic skills such as map reading in order to improve their ability to plan and conduct operations.

Other advisor teams we met with were familiar with the broad goals for ANSF development and had identified activities to develop their ANSF counterpart units, but used less structured approaches to guide their advising efforts. For example, advisor teams in multiple regional commands stated their approach was to rely on interactions with their ANSF counterparts to identify priorities, using this input to develop activities on an ad hoc basis. Similarly, according to a brigade commander serving as an advisor team leader, his team and other advisor teams from his brigade generally identi-

\footnotetext{
10 Department of the Army, Army Field Manual 3-07.10, Advising: Multi-service Tactics, Techniques, and Procedures for Advising Foreign Forces (September 2009). This guidance applies to the Army, Marine Corps, Navy, and Air Force.

11 Army Field Manual 3-07.1, Security Force Assistance (May 2009).
} 
fied development activities in reaction to situations as they arose rather than as part of a longer-term, more structured approach to achieve broad goals. According to several advisor teams, while they received input from various higher headquarters, that input lacked specificity regarding end states they should be trying to achieve for their ANSF units, leading them to use less structured approaches to guide their efforts. For example, the deputy team leader of an advisor team for a high-level Afghan National Army unit with visibility over the efforts of several advisor teams for subordinate ANSF units stated that while his team was able to develop activities intended to enable his counterpart unit to operate independently, he believed that guidance from the regional command did not clearly define the overall desired end state for the ANSF, which made it difficult to determine where to focus their particular advising efforts. Similarly, officials responsible for collecting best practices and lessons learned from SFA advisor teams in one regional command said that, in talking with teams, they found a lack of direction for advisor teams from higher headquarters resulted in what they characterized as a collection of good activities conducted by individual teams over time without a synchronized approach driving towards a tangible end state. Without a more structured approach with clear linkages between objectives or end states linked to development goals for ANSF units, regional commanders cannot be assured that the activities of individual advisor teams are in fact making progress toward established goals. Moreover, having such an approach would help with continuity of effort from one advisor team to the next, since advisor teams typically deploy for 9 months.

\section{The Army and Marine Corps Have Provided the Required Number of SFA Advisor Teams While Managing Ongoing Challenges}

The Army and Marine Corps have provided the required number of SFA advisor teams to Afghanistan based on theater commanders' requests. Recognizing that high ranks and skill specialties were required for advisor teams, theater commander guidance allowed for some substitutions when specific ranks or skills were unavailable, which enabled the Army and Marine Corps to provide the appropriate personnel. The Army's use of brigades to form advisor teams has enabled them to meet requirements but has resulted in leaving large numbers of brigade personnel at their home station locations. To manage these large rear detachments, brigade leadership undertook significant planning to ensure enough stay-behind leadership existed to maintain a sufficient command structure and provide certain training and exercises.

\section{The Army and Marine Corps Have Provided the Required Number of SFA Advisor Teams Based on Theater Commanders' Requests}

In late 2011, ISAF and U.S. Forces-Afghanistan established requirements for coalition and U.S. SFA advisor teams, including specifying the number of teams required, team composition and capabilities, and assignment to ANSF units. Although the numbers of teams have changed over time, according to ISAF, the Army and Marine Corps have provided the required number of SFA advisor teams based on these requests and, as of December 2012, approximately 250 U.S. advisor teams were operating in Afghanistan. 
SFA advisor teams are generally comprised of 9 to 18 advisor personnel — made up of a mix of company- and field-grade officers, and senior non-commissioned officerswith specific specialties such as military intelligence, military police, and signal officers. The composition of advisor teams is tailored to match the needs of their ANSF counterpart. For example, teams at higher echelons of the ANSF (e.g., corps or provincial headquarters) have a higher rank requirement for the advisor team leader and police advisor teams include requirements for military police personnel. According to ISAF, Army, and Marine Corps officials, advisor teams are generally expected to remain with the same ANSF unit for the duration of their approximately 9-month deployments. According to DOD and ISAF officials, the requirement for advisor teams has fluctuated as additional ANSF units have been fielded, and the overall requirement for advisor teams is expected to change as the development of ANSF units progresses. For example, according to ISAF officials, SFA advisor teams currently advise down to the battalion level, but as U.S. forces draw down in Afghanistan and the capability of the ANSF increases, the U.S. advising effort could shift to a brigade-and-higher focus, which could affect the overall number and size of the teams.

U.S. SFA advisor teams began deploying to Afghanistan in early 2012, and the Army and Marine Corps have used a variety of approaches to provide these teams:

- To meet its requirements for the first set of advisor team deployments, the Army tasked three non-deployed brigades to form the bulk of the advisor teams using personnel from their units, with additional non-deployed units tasked to form the remaining teams. These advisor teams then deployed to Afghanistan and were attached to combat brigades already in theater. More recently, the Army shifted its sourcing approach by tailoring the composition and mission of brigades deploying to Afghanistan to further focus on the SFA mission, and began deploying these SFA brigades (SFABs) in November 2012. According to ISAF officials, SFABs include advisor teams that are primarily created using personnel from within the brigade. According to Army officials, as of January 2013, three SFABs have deployed in place of combat brigades, and at least four more U.S. brigades in Afghanistan have been identified to be replaced by SFABs. According to Army officials, the Army will continue to provide some advisor teams using personnel from non-deployed active and reserve units that will join the remaining combat brigades in Afghanistan. Additionally, planning for the remaining brigades and overall force levels in Afghanistan is ongoing and by late 2013 all deploying U.S. brigades may be SFABs.

- To meet the initial deployment of SFA advisor teams beginning in early 2012, the Marine Corps created some teams out of personnel already deployed in Afghanistan and created additional teams using non-deployed personnel generally from the I and II Marine Expeditionary Forces, according to Marine Corps officials. For subsequent deployments of teams, the Marine Corps has created teams using non-deployed personnel from across the Marine Expeditionary Forces that then deploy to Afghanistan as formed teams. 


\section{The Army and Marine Corps Used Substitution Allowances and Individual Augmentees to Address Challenges in Meeting Rank and Skill Requirements}

The Army and Marine Corps have been able to fill SFA advisor teams, but they continue to face challenges meeting specific rank and skill requirements. In 2011, we reported on challenges the Army was experiencing providing high-ranking personnel with specialized skills for the advising mission in Afghanistan. ${ }^{12}$ According to Army and Marine Corps officials, meeting the rank and skills required for SFA advisor teams, including those as part of SFABs, continues to present a challenge given the limited availability of such personnel across the services. To help address these challenges, theater commanders, in coordination with the Army and Marine Corps, have outlined a set of substitution guidelines, to allow flexibility in the rank and skill requirements. For instance, specific rank requirements can generally be substituted with an individual one rank above or below the requirement. Similarly, there are guidelines for different skills and specialties that may be substituted for one another. For example, a team may have a requirement for a specific type of intelligence officer, but the substitution guidance identified other types of intelligence personnel that could be used to meet this requirement such as a counterintelligence or signals intelligence analyst. Army Forces Command officials told us that because the required number of ranks and specialties for SFA advisor teams exceeds the total number of such personnel that exist in a typical brigade, the ability to substitute certain ranks and skills with other available personnel was critical to meeting the requirement for most advisor teams and for all three of the first deploying SFABs. Army officials recognized that substitutions would need to occur both within and among brigades. According to sourcing officials and officials from one of the brigades tasked to provide the first set of advisor teams, the following are examples:

- While 40 majors were required to fill the specified number of teams, the brigade had only 25 majors on hand. Recognizing this, the Army's plan called for substituting captains for majors in order to meet the requirement.

- The requirement for certain intelligence officers exceeded that which existed in the brigade. Therefore, brigade leadership used lower ranking military intelligence officers or other officers with sufficient related experience.

According to Army officials, the rank and skill requirements, as well as the reliance on substitutions, are expected to continue with the use of SFABs. As the Army and Marine Corps began to form the teams, they also worked with their force providers in order to utilize individual augmentees from active and reserve non-deployed units to help meet the rank and skill requirements for SFA advisor teams. For example, an official from a Marine Expeditionary Force responsible for providing many of the first advisor teams stated that the unit used reservists to fill over 130 advisor slots, and the Marine Corps expects to continue to use them to fill subsequent teams.

12 GAO-11-760, available at www.gao.gov/products/GAO-11-760. 


\section{The Army Is Taking Steps to Manage Large Rear Detachments That Result from SFA Advisor Team Sourcing Approaches}

The Army's sourcing approaches enabled it to meet theater requirements for SFA advisor teams, but resulted in brigades leaving large numbers of personnel at home station locations. For the first set of Army deployments, the three brigades identified to source the bulk of the teams left the majority of their personnel at home station. For example, according to brigade officials, one brigade deployed approximately 370 people to create advisor teams, leaving approximately 3,100 personnel (approximately 90 percent) behind at home station. According to Army officials, SFABs reduce the size of the rear detachments because a larger percentage of the brigade's personnel are to be deployed, although they recognized SFABs would continue to result in large rear detachments. For example, two of the first SFABs to deploy each left roughly 2,000 personnel at home station. Because the advisor team requirement calls for high numbers of company- and field-grade officers and senior non-commissioned officers, as well as specific skill specialties, staffing the teams required the brigades to deploy a significant portion of their leadership and expertise, including the brigade commanders and many battalion, company, and platoon commanders, for the advisor mission. As a result, according to Army Forces Command officials and officials from two brigades, brigade leadership had to undertake significant planning to ensure that enough stay-behind leadership existed to maintain a sufficient command structure and the unit leadership needed to conduct certain training, such as artillery and other live-fire exercises. In order to help brigades in this planning, Army Forces Command has issued guidance for the training and employment of rear detachments during advisor team deployments, including missions the force may be assigned to, training expectations, and equipment maintenance responsibilities. For example, one brigade that deployed many of the first set of advisor teams consolidated its rear detachment into smaller numbers of more fully manned platoons to ensure appropriate leadership existed for each platoon. In addition, the brigade leadership developed a training plan for the rear detachment to maintain proficiency in critical tasks while awaiting reintegration of deployed personnel.

\section{The Army and Marine Corps Have Developed Programs to Train Advisor Teams, but Teams Differed in the Extent to Which They Had Mission-Specific Information Prior to Deployment}

The Army and Marine Corps have developed standardized predeployment training programs for SFA advisor teams in Afghanistan, but teams varied in the extent to which they had access to mission-specific information prior to deploying that they believed would help them prepare for their specific advising missions.

\section{The Army and Marine Corps Have Developed Predeployment Training Programs for SFA Advisor Teams}

SFA advisor teams take part in a broad set of training activities both at home station and at training centers in the months leading up to their deployment. ISAF has estab- 
lished minimum training requirements for SFA advisor teams from all coalition countries, including the United States. These training requirements include both individual advisor knowledge and skills, such as understanding how to work through an interpreter, and collective team knowledge and skills, such as how the advisor team will assess ANSF unit capabilities and provide force protection and sustainment. ISAF envisions that this training will be conducted using a combination of individual and teambased training. In accordance with these requirements, the Army and Marine Corps have each developed a program of instruction for predeployment training, which generally occurs in three stages:

- Home-Station Training. Home-station training includes individual and teamlevel combat skills training provided to all deploying forces to Afghanistan. Typically, SFA advisor teams are formed prior to the beginning of this training. Topics include combat lifesaver training, various weapons and driving qualifications, and countering improvised explosive devices. During this period, teams also begin to gather information regarding their specific advising assignment in order to conduct mission analysis, shape the next two stages of their training, and establish their initial plan for their advising missions. ${ }^{13}$ For example, officials at the Joint Readiness Training Center Operations Group, which conducts culminating training exercises for Army advisor teams and SFABs, told us that it is during this time that they begin to work with commanders to design their culminating training exercise.

- Advisor-Specific Training. Advisor-specific training is focused on language, culture, counterinsurgency, and advisor skills. Army advisor teams generally receive advisor-specific training during an 8-day course provided by the $162^{\text {nd }}$ Infantry Training Brigade. ${ }^{14}$ Marine Corps teams receive training at the Advisor Training Cells at their respective Marine Expeditionary Force home stations, as well as the Advisor Training Group at the Marine Corps Air Ground Combat Center. ${ }^{15}$ Both the Army and Marine Corps training includes courses such as overviews of Afghan security force institutions, how to use an interpreter, and techniques for building rapport. The training also utilizes role

13 Mission analysis is used to study the assigned tasks and to identify all other tasks necessary to accomplish the mission. According to Joint Publication 5-0 Joint Operation Planning, mission analysis is critical because it provides direction to the commander and the staff, enabling them to focus effectively on the problem at hand.

14 Army officials told us that some advisor personnel receive an 8 -week course from the $162^{\text {nd }}$ Infantry Training Brigade, which includes both combat skills training and advisor-specific training and is based on a variety of factors including the training capabilities of home units.

15 Advisor training cells are training sites located at each Marine Expeditionary Force home station, which provide training capabilities for advisor teams that work with foreign security forces, including SFA advisor teams in Afghanistan. The Advisor Training Group is located at the Marine Corps Air Ground Combat Center in Twentynine Palms, California, and its purpose is to train Marine Corps teams that advise, mentor, and train foreign military, police, and border units in operational techniques and procedures. 
players in practical exercises to simulate engagements with key Afghan civilian and military leaders in different situations.

- Culminating Training Exercise. This training includes situational training exercises and a culminating training exercise that integrates ANSF role players into a simulated deployed environment in order to exercise the advisor teams' ability to advise their ANSF counterpart units. For Army advisor teams, this exercise is incorporated into the culminating training exercise of the brigade under which they will operate in Afghanistan, when possible, and is conducted at the Joint Readiness Training Center at Fort Polk, Louisiana, or other combat training centers. These exercises include training based on the level (e.g., brigade, battalion) and type (e.g., army, police) of the ANSF unit that teams will be advising and their specific areas of responsibility in Afghanistan, individual and team proficiency assessments, and live-fire drills, such as combat patrols. Marine Corps advisor teams receive similar training at the Advisor Training Group, though this training does not include the combat unit with which they will be operating in Afghanistan.

The Army, Marine Corps, and ISAF have established mechanisms to gather feedback on predeployment training from advisor teams in Afghanistan in order to update and refine training for the advisor mission. Both the Army and Marine Corps centers for lessons learned have ongoing efforts in Afghanistan to collect observations and best practices for SFA advisor teams. Additionally, the 162nd Infantry Training Brigade employs liaison officers at ISAF and the regional commands, among other places, to collect lessons learned and after-action reports from advisor teams in Afghanistan, which are then incorporated into advisor training. Officials from the 162nd Infantry Training Brigade said that, based in part on this feedback, the advisor training has changed significantly since the first SFA advisor teams began going through the training in January 2012, and that the program of instruction will continue to evolve. For example, officials from two of the first SFA advisor teams told us that the advisor training was too focused on classroom instruction. Officials from the $162^{\text {nd }}$ Infantry Training Brigade said that they had heard similar concerns, and later iterations of SFA advisor team training was updated to provide greater balance between classroom training and practical exercises that use cultural role players. Further, between August 2012 and October 2012, ISAF conducted a survey of U.S. and coalition nation SFA advisor team personnel on predeployment training in order to provide advisor insights to U.S. and NATO training centers and made several recommendations to improve predeployment training. For example, ISAF recommended that advisor teams contact the unit they will be replacing to fine tune their training in order to meet the challenges they will face upon deployment.

\section{Advisor Teams Varied in the Extent to Which They Had Access to Information to Help Prepare for Their Specific Advising Missions Prior to Deployment}

ISAF's minimum training requirements direct advisor teams to conduct mission analysis prior to deployment in order to develop plans for advising their ANSF counterpart 
unit. Further, the Army's Field Manual for Security Force Assistance, states that an indepth understanding of the operational environment - including a clear understanding of the theater, population, and the foreign security forces and capabilities with which they are working - is critical to planning and conducting effective SFA. ${ }^{16}$ According to some advisor team officials and ISAF officials tasked with gathering lessons learned from advisor teams and identifying potential challenges, the personalities and capabilities of each ANSF unit and district are unique, and advisor teams need specific information on their ANSF counterpart unit as well as the efforts of the advisor teams currently working with the unit prior to deployment in order to be successful. In addition, some advisors stated that having specific information about the operational environment where teams will be deployed would be beneficial in determining where to place emphasis during training. For example, some advisor teams we spoke with are able to walk to their counterpart unit's headquarters, while other teams had to travel longer distances to accompany their counterpart units. Having this type of specific information about their operating environment could be helpful for advisor teams in tailoring some of their more general combat training at home station.

Advisor teams varied in the extent to which they had access to information to help prepare for their specific advising missions prior to deployment. Advisor teams may gain access to this information through a variety of ways. For example, officials from the 162nd Infantry Training Brigade said that they coordinate video teleconferences between advisor teams going through advisor training and deployed advisor teams with the goal that advisor teams are able to talk to the SFA advisor team that they will replace to help the deploying team better understand its specific mission and the unit that it will be advising. Advisor teams can also utilize secure networks to gather missionspecific information. For example, much of the information on advising and general operations in Afghanistan (e.g., daily and weekly update briefs, details of the advisor teams' interactions with ANSF units, and regional command campaign plans) is stored and shared on the Combined Enterprise Regional Information Exchange System-ISAF (CENTRIXS-I) network - a network that is widely used by U.S. and coalition forces in Afghanistan, but with limited access in the United States. Additionally, advisor teams may take part in predeployment site surveys in which commanders take staff members to theater and meet with the units they will be replacing to learn more about the mission they will support. According to the Army Field Manual for Security Force Assistance, the predeployment site survey should, among other things, provide information on the organization, leadership, and capabilities of the foreign unit that will be advised, as well as an overview of the operational area. ${ }^{17}$ ISAF minimum training requirements also require that advisor teams conduct predeployment site surveys as part of their SFA mission analysis and planning.

16 Army Field Manual 3-07.1, Security Force Assistance (May 2009).

17 Army Field Manual 3-07.1, Security Force Assistance (May 2009). 
We found differences in the extent to which advisor teams were actually able to gain access to mission-specific information throughout their predeployment training. For example,

- While some SFA advisor teams told us that mission-specific information shared on CENTRIXS-I is beneficial in shaping their predeployment training and mission analysis, we found that advisor teams varied in the extent to which they were able to access this system and thus the information contained therein throughout their predeployment training. Some advisor teams had access to CENTRIXS-I at home station. For example, officials from one brigade that provided SFA advisor teams said that they recognized the value of CENTRIXS-I in gathering specific information from units on the ground in order for teams to conduct their mission analysis and early planning, and proactively took steps to gain access to the network at home station early on in predeployment training, and were able to obtain access for its SFA advisor teams 5 months prior to deploying. However, other advisor teams said that they had limited or no access to this network at their home stations, thus limiting the information available to the teams to shape training, conduct mission research, and develop situational awareness before arriving in Afghanistan. Advisor teams are able to access CENTRIXS-I once they arrive at the 162nd Infantry Training Brigade and the Advisor Training Group training sites. However, teams are at these locations for a short time (i.e., less than 30 days) in the midto-late stages of training. Advisor teams with limited or no access to CENTRIXS-I at home station may be unable to fully leverage mission-specific information to (1) either shape their training prior to going to these locations or (2) continue to fully maximize the up-to-date information contained therein to prepare for their missions after they leave the training sites.

- Advisor teams varied in their ability to send representatives on predeployment site surveys to Afghanistan. Unit commanders and theater commands determine the numbers of personnel that take part in the survey, taking into consideration limitations on the ability of certain locations to provide transportation, housing, and other support. According to an ISAF official, units tasked with the advising mission are encouraged to take some representatives from their advisor teams on these surveys. According to a U.S. Forces-Afghanistan official, there has been at least one recent case where a predeployment site survey team sent to Afghanistan was augmented with additional personnel in order to accommodate the need to visit multiple locations. In contrast, some advisor teams we spoke with said that they did not send representatives from their individual teams on these site surveys, which limited their ability to shape their training and their understanding of the environment in which they would be operating. For example, one advisor team said that it did not know the specifics of the operating environment when conducting home station training, such as details about security and movement, and that the opportunity to conduct a predeployment site survey would have been helpful for the team's mis- 
sion preparation. Another unit that was organized into three advisor teams reported that they did not take part in a predeployment site survey and thus faced significant challenges during their first 45 days of deployment because they were unaware that logistic support arrangements for the teams in Afghanistan had not been established.

DOD officials acknowledged that increased information prior to deployment would benefit advisor teams, but added that resource constraints are a consideration in determining how to expand access to certain information sources. Nonetheless, without a more complete understanding of the capabilities of the ANSF counterpart units to be advised and the operating environment in which they will be advising prior to deploying, it may take advisor teams more time after deploying to maximize their impact as advisors.

\section{Conclusions}

The use of SFA advisor teams to develop and support the ANSF are a key element of the U.S. and ISAF strategy to transition lead security responsibility to Afghanistan while drawing down combat forces. By ensuring that SFA advisor teams have structured approaches with clear linkages between end states, objectives, and milestones that are in support of broad goals for ANSF units, theater commanders can enhance the ability of advisor teams to develop their ANSF counterparts. In addition, this will enable theater commanders to better gauge an ANSF unit's progress towards their broader development goals and facilitate continuity of effort from one advisor team to the next. Lastly, by improving the availability of mission-specific information prior to deployment, the Army and the Marine Corps will ensure that SFA advisor team have the information necessary on their specific ANSF counterpart and the operational environment to better inform training. Moreover, such information would enhance the ability of advisor teams to prepare for and undertake their efforts immediately upon deployment.

\section{Recommendations for Executive Action}

To ensure that the activities of individual advisor teams are more clearly linked to ISAF and regional command goals for overall ANSF development, we recommend that the Secretary of Defense, in consultation with the commander of U.S. Central Command, direct theater commanders in Afghanistan to work with brigade commanders and advisor teams to identify specific end states, objectives and milestones for developing their ANSF counterparts that are in support of the broad theater goals to guide their advising efforts during their deployment.

To enhance the ability of SFA advisor teams to prepare for and execute their mission, we recommend that the Secretary of the Army and the Commandant of the Marine Corps take steps to improve the availability of mission-specific information during predeployment training. Such steps could include:

- Expanded access to the data and information contained in CENTRIXS-I; and, 
- Increased opportunities, in coordination with U.S. Central Command, for advisor team leaders to participate in predeployment site surveys with the teams they are expected to replace.

\section{Agency Comments and Our Evaluation}

In written comments on a draft of this report, DOD partially concurred with our recommendations. DOD also provided technical comments, which we incorporated where appropriate.

In its comments, DOD partially concurred with our first recommendation that the Secretary of Defense, in consultation with the commander of U.S. Central Command, direct theater commanders in Afghanistan to work with brigade commanders and advisor teams to identify specific end states, objectives, and milestones for developing their ANSF counterparts that are in support of the broad theater goals to guide their advising efforts during their deployment. Also, DOD provided comments regarding the command relationships and guidance affecting the advisor teams. Specifically, DOD stated that the issue of linking advisor teams with regional commanders and the theater commander to identify specific end states, objectives, and milestones resides within the operational level and not at the strategic level with the Secretary of Defense and U.S. Central Command. The department further stated that the Commander, International Security Assistance Force (COMISAF), is the theater commander and produces the operation plans for Afghanistan, which provide the end states, objectives, and milestones for the campaign, including efforts to develop the ANSF and ministerial-level agencies. COMISAF also issues guidance for developing the ANSF and ministerial agencies to include end states, objectives, and milestones. Further, DOD noted that regional commanders receive their guidance and direction in part through the OPLANs and other guidance issued by COMISAF. The department also stated that brigade commanders, SFABs, and SFA advisor teams are operationally and/or tactically controlled by the regional commanders. DOD stated that guidance from the regional commanders for these subordinate elements should include the guidance provided by $\mathrm{CO}$ MISAF regarding development of the ANSF. Lastly, DOD stated that individual ANSF elements advised by SFA advisor teams and SFABs have different levels of capabilities and unique circumstances involved in developing those capabilities. Therefore, DOD stated that commanders at the operational and tactical level should have sole responsibility for directing the development of the individual ANSF elements.

We agree that it is the responsibility of commanders, particularly regional commanders, at the operational and tactical level, to direct SFA advisor teams to develop individual ANSF elements. As we noted in our report, regional commands have overall responsibility for operations in their geographic area, including setting goals for the advising mission. We further noted that the missions for advisor teams are defined in multiple ISAF and DOD plans, directives, and orders and that the regional commands amplify this guidance by providing key advising goals based on the developmental needs of the ANSF in each region. However, we found that it is largely left to advisor teams to develop their approach for working with their ANSF counterpart units and 
that advisor teams varied in the extent to which their approaches identified activities based upon specific objectives linked to ANSF development goals. Therefore, we recommended that theater commanders in Afghanistan should work with brigade commanders and advisor teams to identify specific end states, objectives and milestones for developing their ANSF counterparts that are in support of the broad theater goals to guide their advising efforts during their deployment. We agree with the department's view that directing the development of the individual ANSF elements should be the sole responsibility of commanders at the operational and tactical level. We believe that our recommendation does not conflict with this principle but rather calls for the Secretary of Defense, in consultation with the Commander of U.S. Central Command, to direct the operational commander to ensure that these actions are taken.

Regarding our second recommendation, we recommended that the Secretary of the Army and the Commandant of the Marine Corps take steps to improve the availability of mission-specific information during predeployment training, and provided two examples of such steps for illustrative purposes. DOD commented separately on these examples. Specifically, with respect to the step calling for expanded access to the data and information contained in CENTRIXS-I, DOD concurred and noted that actions had been taken to install CENTRIXS-I kiosks at U.S bases and overseas locations and plans were underway to install additional kiosks. Also, DOD noted that while CENTRIXS-I is a specific capability, it appears that the intent of our recommendation is to expand information flow by any means available, and DOD suggested that we rephrase the first step to read: "Expand access to secure networks in order to gather data and information." We agree that the intent of our recommendation is to expand information flow and to recognize, as noted in our report, that other information sources exist beyond CENTRIXS-I. Based on our discussions with command and advisor team personnel, CENTRIXS-I was cited as an important information source and therefore we cited it as an example in our report. We believe that, as currently worded, our recommendation provides flexibility for the department to determine a range of options for improving the availability of information to advisor teams.

With respect to the step calling for increased opportunities for advisor team leaders to participate in predeployment site surveys, DOD partially concurred. The department stated that advisor teams and the leadership of brigades must collaborate and use the site survey as well as the brigade's intelligence infrastructure to support the teams in getting situational awareness. Further, DOD further noted that space and logistical constraints may limit participation in a brigade's site survey. Given the critical nature of the SFA advisor team mission, DOD noted that team leaders should be given priority to participate in a predeployment site survey, but that a balance must be met regarding the comprehensive nature of the mission in Afghanistan. Additionally, the department stated that while the Secretary of the Army and the Commandant of the Marine Corps can explore timing opportunities for advisor team leaders to participate in predeployment site surveys, the Afghanistan theater of operations has responsibility for ultimate approval for a site-survey visit request. As a result, the department recommended that we rephrase the second step to include the wording "in coordination with U.S. Central Command." We agree that various factors can affect the composition 
of the personnel participating in the site surveys and that the theater of operations has responsibility to approve visit requests. Our report specifically notes that unit commanders and theater commands determine the numbers of personnel that take part in the predeployment site survey, and take into consideration limitations on the ability of certain locations to provide transportation, housing, and other support. Based on DOD's comments, we modified the text of our second step as DOD suggested.

We are sending copies of this report to the appropriate congressional committees. We are also sending copies to the Secretary of Defense; the Chairman of the Joint Chiefs of Staff; the Secretary of the Army; the Commandant of the Marine Corps; and the Commander of U.S. Central Command. In addition, the report will also be available on our website at http://www.gao.gov.

If you or your staff have questions about this report, please contact me at (202) 512-9619 or pickups@gao.gov. Key contributors to this report are listed in appendix III.

Sharon L. Pickup, Director, Defense Capabilities and Management

\section{Appendix I: Scope and Methodology}

To determine the extent to which the Department of Defense (DOD), in conjunction with the International Security Assistance Force (ISAF), has defined Security Force Assistance (SFA) advisor team missions, goals, and objectives, we reviewed doctrine and guidance from the Army, Marine Corps, and theater commanders, including the Army Field Manual 3-07.1 Security Force Assistance and the ISAF SFA Concept and Implementation Guidance. We also examined key planning documents, such as operational plans and orders, theater commanders' requests for forces, and select advisor team mission briefs and after-action reports. Additionally, we interviewed officials in the United States from the Office of the Secretary of Defense, Department of the Army, Headquarters Marine Corps, as well as officials in Afghanistan from ISAF, ISAF Joint Command, regional commands, and U.S. Army and Marine Corps advisor teams.

To determine the extent to which the Army and Marine Corps have been able to provide SFA advisor teams, we reviewed documents such as theater and combatant commanders' requests for forces that establish personnel requirements for SFA advisor teams and Army and Marine Corps sourcing documents, including execution orders and other manning guidance. We also examined ISAF, ISAF Joint Command, and Army and Marine documents detailing the structure and composition of the SFA advisor teams, including the ISAF SFA Concept and Implementation Guidance, theater commander operational and fragmentary orders, and unit and advisor team briefings. Additionally, in addition to the officials mentioned above, we also interviewed officials in the United States from Army Forces Command, Marine Corps Central Command, 1st Marine Expeditionary Force, U.S. Central Command, officials from Army brigades that provided SFA advisor teams, and U.S. Army and Marine Corps advisor team personnel in the United States and Afghanistan. 


\section{THE QUARTERLY JOURNAL}

To determine the extent to which the Army and Marine Corps have developed programs to train SFA advisor teams for their specific missions in Afghanistan, we reviewed theater commanders' and service training requirements for SFA advisor teams, such as U.S. Central Command theater training requirements, ISAF minimum training requirements for SFA advisor teams, and Army and Marine Corps training requirements for SFA advisor teams. We also examined documents detailing Army and Marine Corps advisor training programs, such as concept briefs and curriculum documents from the 162nd Infantry Training Brigade, the Joint Readiness Training Center, the Marine Corps Advisor Training Group, and Marine Corps Advisor Training Cell. We also reviewed after-action reports and lessons-learned documents from SFA advisor teams.

Additionally, we interviewed officials from the Army 162nd Infantry Training Brigade, Joint Readiness Training Center, 1st Marine Expeditionary Force Advisor Training Cell, Marine Corps Advisor Training Group, and U.S. Army and Marine Corps advisor personnel conducting training in the United States and deployed in Afghanistan, as well as from those organizations mentioned earlier.

We visited or contacted officials from the following organizations in the United States and Afghanistan during our review:

DOD Organizations in the United States

- Office of the Secretary of Defense, Arlington, Virginia

- U.S. Central Command, Tampa, Florida

- U.S. Army

o Department of the Army Headquarters, Arlington, Virginia

o U.S. Army Forces Command, Fort Bragg, North Carolina

o 162nd Infantry Training Brigade, Fort Polk, Louisiana

o Joint Readiness Training Center, Fort Polk, Louisiana

o 101st Airborne Division, Fort Campbell, Kentucky

- U.S. Marine Corps

o Headquarters, Marine Corps, Arlington, Virginia

o Marine Corps Central Command, Tampa, Florida

o 1st Marine Expeditionary Force, including its Advisor Training Cell, Camp Pendleton, California

o Advisor Training Group, Marine Corps Air Ground Combat Center, Twentynine Palms, California

DOD and International Entities in Afghanistan

- North Atlantic Treaty Organization (NATO) entities, including the following:

o ISAF, ISAF Commander's Advisory and Assistance Team, and ISAF Joint Command, Kabul, Afghanistan

o NATO Training Mission-Afghanistan, Kabul, Afghanistan 
o Regional Command headquarters and staff:

- Regional Command-East (Commanded by 1st Infantry Division, U.S. Army), Bagram Air Field, Afghanistan

- Regional Command-South (Commanded by 3rd Infantry Division, U.S. Army), Kandahar Air Field, Afghanistan

- Regional Command-Southwest (Commanded by 1st Marine Expeditionary Force (Fwd), U.S. Marine Corps), Camp Leatherneck, Afghanistan

- U.S. Forces-Afghanistan, Kabul, Afghanistan

- U.S. Army and Marine Corps Units, Personnel, and Advisor Teams deployed in Afghanistan:

o 4th Brigade, 4th Infantry Division, U.S. Army

o 2nd Stryker Brigade, 2nd Infantry Division, U.S. Army

- 162nd Infantry Training Brigade training liaison officers

o 23 SFA advisor teams in Afghanistan, including the following:

- 7 Army advisor teams in Regional Command-East

- 10 Army advisor teams in Regional Command-South

- 5 Marine Corps advisor teams in Regional Command-Southwest

- 1 Army advisor team in Regional Command-West.

As part of this review, we selected an illustrative, non-generalizable sample of deployed U.S. Army and Marine Corps SFA advisor teams in Afghanistan. We worked with theater commands in Afghanistan to identify and meet with a selection of advisor teams that included both Army and Marine Corps advisor teams, advisor teams operating in different regional commands, and advisor teams assigned to various types (e.g., army, police, operational coordination center, etc.) and levels (e.g., corps, brigade, battalion, etc.) of the ANSF. Ultimately, we met with 23 deployed U.S. advisor teams in Afghanistan operating in four different regional commands' areas of operations - 18 Army teams and 5 Marine Corps teams.

We conducted this performance audit from June 2012 to April 2013 in accordance with generally accepted government auditing standards. Those standards require that we plan and perform the audit to obtain sufficient, appropriate evidence to provide a reasonable basis for our findings and conclusions based on our audit objectives. We believe that the evidence obtained provides a reasonable basis for our findings and conclusions based on our audit objectives.

\section{Appendix III: GAO Contact and Staff Acknowledgments}

\section{GAO Contact}

Sharon Pickup, (202) 512-9619 or pickups@gao.gov 


\section{THE QUARTERLY JOURNAL}

Staff Acknowledgments

In addition to the contact named above, James A. Reynolds, Assistant Director; Virginia Chanley; Carole Coffey; Grace Coleman; Mark Dowling; Kasea Hamar; Marcus Oliver; Luis Rodriguez; and Sally Williamson made key contributions to this report.

\section{Related GAO Products}

Building Partner Capacity: Key Practices to Effectively Manage Department of Defense Efforts to Promote Security Cooperation, GAO-13-335T (Washington, D.C.: GAO, February 2013), available at http:/www.gao.gov/products/GAO-13-335T.

Afghanistan: Key Oversight Issues, GAO-13-218SP (Washington, D.C.: GAO, February 2013), available at http://www.gao.gov/products/GAO-13-218SP.

Afghanistan Security: Security Transition, GAO-12-598C (Washington, D.C.: GAO, September 2012).

Observations on U.S. Military Capabilities to Support Transition of Lead Security Responsibility to Afghan National Security Forces, GAO-12-734C (Washington, D.C.: GAO, August 2012).

Afghanistan Security: Long-standing Challenges May Affect Progress and Sustainment of Afghan National Security Forces, GAO-12-951T (Washington, D.C.: GAO, July 2012), available at http://www.gao.gov/products/GAO-12-951T.

Interim Results on U.S.-NATO Efforts to Transition Lead Security Responsibility to Afghan Forces, GAO-12-607C (Washington, D.C.: GAO, May 2012).

Security Force Assistance: Additional Actions Needed to Guide Geographic Combatant Command and Service Efforts, GAO-12-556 (Washington, D.C.: GAO, May 2012), available at http://www.gao.gov/products/GAO-12-556.

Iraq and Afghanistan: Actions Needed to Enhance the Ability of Army Brigades to Support the Advising Mission, GAO-11-760 (Washington, D.C.: GAO, August 2011), available at http://www.gao.gov/products/GAO-11-760. 


\section{Connections: The Quarterly Journal Submission and Style Guidelines}

Connections accepts manuscripts in the range of 2,000 to 5,000 words, written in a lucid style for a target audience of informed defense and security affairs practitioners and academics. All manuscripts should be submitted to the Connections editorial office electronically at PfPCpublications@marshallcenter.org. They should feature the author's name, current institutional affiliation, and a provisional title at the top of the first page, and should include footnotes where necessary.

Preferred themes for the FY 2014 publication year include:

Cyber Security

Environmental Security

Military in Crisis Management

Connected Forces Initiative

Security, Stability, and Reconstruction Operations

Good Governance in Security and Defense

Contemporary Challenges in Defense Education

Armed Non-state Groups

Border Security

Reshaping and Reforming Armed Forces

For questions on footnotes and references, please refer to the Chicago Manual of Style, at http://www.chicagomanualofstyle.org/ tools_citationguide.html.

Unsolicited manuscripts are accepted on a rolling basis at the discretion of the PfPC Editorial Board. 
The views expressed in all CONNECTIONS publications are solely those of the contributing authors, and do not represent official views of the PfP Consortium of Defense Academies and Security Studies Institutes, participating organizations, or the Consortium's editors.

The Operations Staff of the PfP Consortium of Defense Academies and Security Studies Institutes is located at the George C. Marshall European Center for Security Studies:

Gernackerstrasse 2

Bldg. 102, Room 306B

82467 Garmisch-Partenkirchen, Germany Phone: +49 8821750 2333, Major Enrico Müller

E-mail: pfpconsortium@marshallcenter.org www.pfpconsortium.com

For all information regarding CONNECTIONS please contact the PfPC Operations Staff at:

pfpcpublications@marshallcenter.org or by using the information above. 